تطوير تدريبات التوازن وتاثيرها على بعض القدرات البلنية الخاصة ومستوى اداء مهارة الميزان الجانبى بميل الجذع فى المستوى الافقى لناشئات الجمباز الايقاعي

م.د// ندا عبد الوهاب عبد الرحيم احمد الردي

مدرس بقسم التدريب الرياضي وعلوم الحركة

تخصص جمباز ايقاعي - كلية التربية الرياضية للبنات - جامعة الاسكندرية

\title{
التعريف بالبحث:
}

المقدمة واهمية البحث:

ان التطـور الـذى حصـل فـى المجـال الرياضــي بشـكل عـام جـاء نتيجـة البحـوث العلميـة الجـادة

التـى سـاعدت علـى الرقـي فـي كافـة الالعـاب وكـان نصـيب لعبـة الجمبـاز الايقـاعي فـى ذلــــ اوفـر للغايــة لمكانتهـا مـن الالعـاب الاولمبيــة ، ويعتبـر التـوازن العضــلي عنصــر اساسـي مـن العناصـر المكونــة لـلاداء الحركـي كمـا تعتبـر احـد العوامـل التـى تشـاعد اللاعبـة على تحقيـق الكفايـة العضـلية

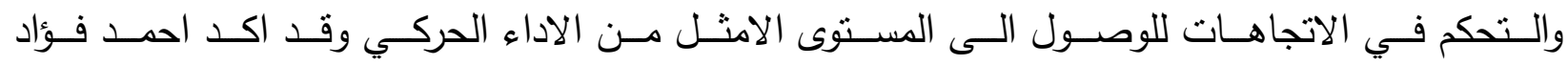

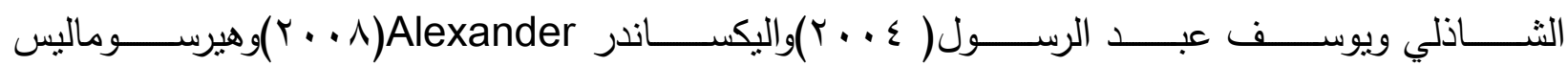
Hrysomallis (1 (1 ـ ب)اهميـة التـوازن بالنسـبة لـلاداء الحركى فـى المهـارات والانشــة التـى تتطلـب تغييـرا او عنـدما يتغيـر وضـع الجسـم اتزانـي الـى وضـع اخـر وتحتـاج اللاعبـة فيـه الـى اسـتعادة اتزانهـا لاسـتكمال اسـتمرارية الحركـة او لبـدء حركـة جديـدة كمـا هـ فـى الجمبـاز الايقـاعي - الجمبـاز الفنـي -

$$
\text { الجودو (乏: }
$$

وتلعـب مهـارات التـوازن دوراً هامـا في الجمبـاز الإيقـاعى حيـث ذكـر كيمـو رتزوجلـو ،وديـرى

، ميتزانيدو و تزيتز Kioumourtzoglou E, Derri V.,Metzanidou O, TzetzisG

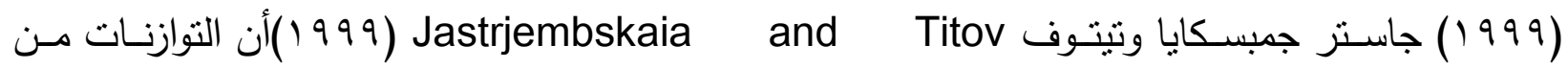

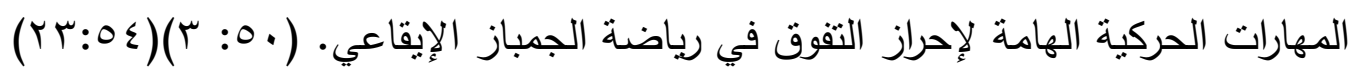

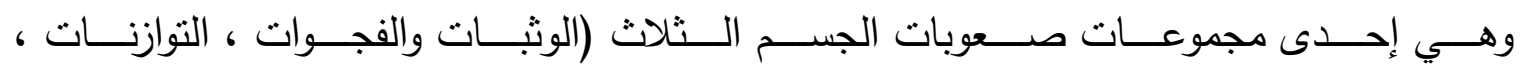

الـدورانات) التي يجـب أن تشـملها الجمـل الحركيـة في رياضــة الجمبـاز الإيقـاعي وذلـك بواقـع صـعوبة مـن كـل مجموعـة مـن مجموعـات صـعوبات الجسـم كحـد أدنـى و 9 صـعوبات مـن كـل المجموعـات

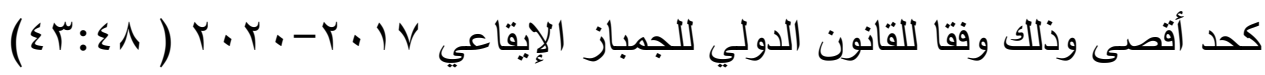

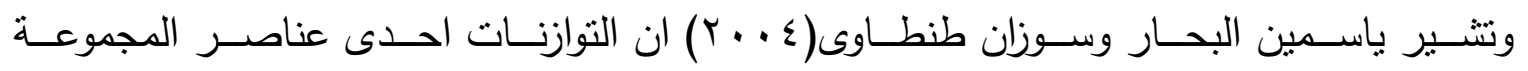
الاساسـية للجسـم والتهى يعتمـد أداء اللاعبـة فيهـا على العديـد مـن الصـفات البدنيـة العامـة والخاصـة ، وبخاصـةًة صـفة التوازن التي تعـد واحدة مـن بـين أهـم الصـفات البدنيـة الخاصـة التهي تحتاجهـا لاعبـات الجمباز الايقاعي في تتفيذ المبادئ الأساسية للتوازنات.(r؟ : بس ا)

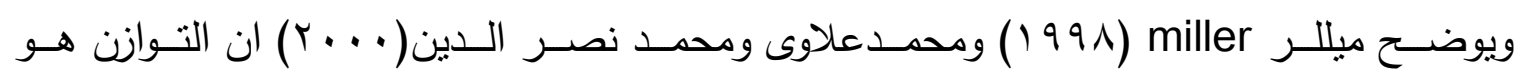


القـدرة على الاحتفـاظـ بثبـات الجسـم فـوق قاعـدة ارتكـاز محـدودة كمـا فـى وضــع الوقـوف على قـدم

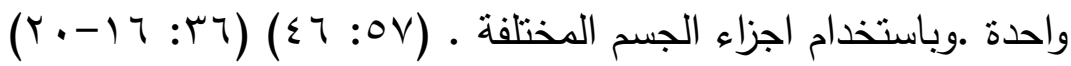

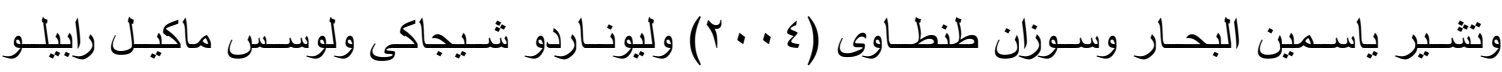

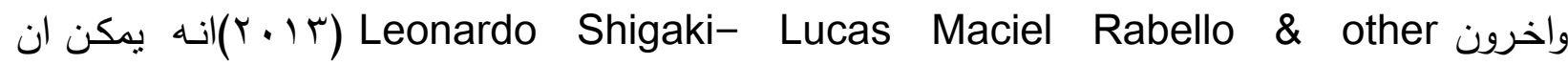

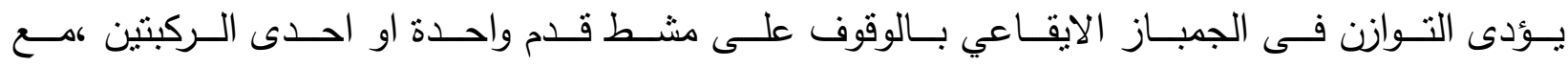
الاحتفـاظ بثبـات اوضــاع اجـزاء الجسـم المختلفـة كالجـذع والاذرع والارجـل وتسـمى الرجـل التـى ترتكـز عليهـا اللاعبـة رجـل الارتكاز(الرجـل الداعمـة Supporting امـا الرجـل الاخـرى فتسـى الرجـل

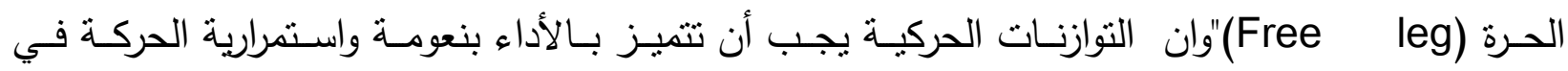

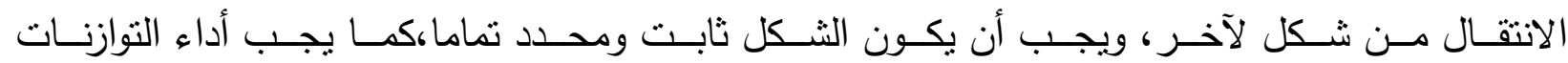
بـالتوافق مــع حركـة الأداة المسـتخدمة (سـواء مـن حركـات المجموعـات الأساسـية أو الغيـر أساسـية لكأداة). (r

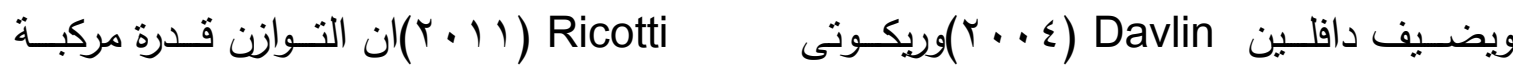

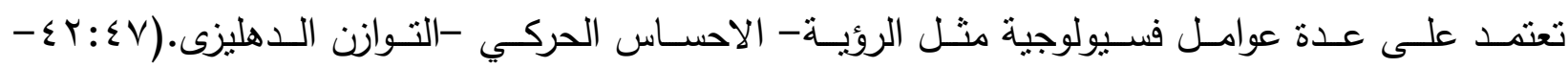

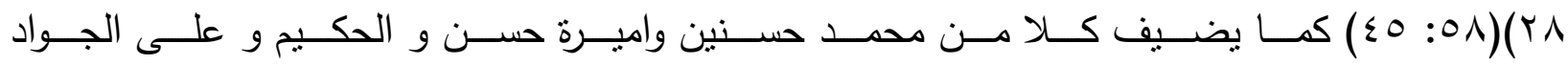

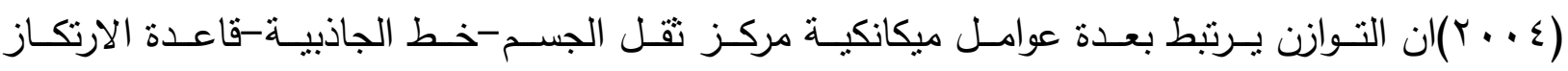
واذا كـان المطلـوب التوازن الحركي فيلـزم تحريك خط الجاذبيـة السى خـارج قاعدة الارتكـاز وذلك حتى تـتم الحركـة واذا كـان المطلـوب التـوازن الثابـت فيجب ان يقع خط الجاذبيـة داخـل قاعـدة الارتكـاز فـإن وضـع مركـز تــل الجســم فـوق قاعـدة الإرتكـاز هـو الثـرط الأساسـي للحفـاظ علـى التـوازن ، وخـروج

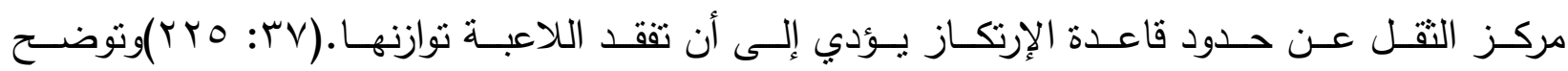
ياسـمين البحـار وسـوزان طنطـاوى (ع . . r) أن ثبـات اللاعبـة يحـد مـن خـلال حجـم قاعـدة الإرتكــاز

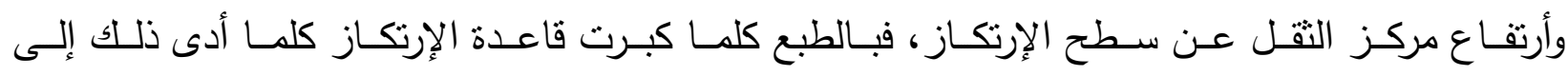
ثبـات أفضــل في الوضـع، كذللك يصـبح الثبـات أفضـل حينمـا يـنخفض مركز تـلـل جسـم اللاعبـة، لـذا فـإن التـوازن الــي يـؤدى على أطـراف الأصـابع كما فـي الوقـوف العـالي على الأمشـاط يصـبح الأتـزان

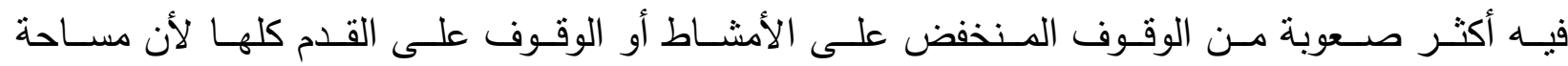
قاعدة الإرتكاز تصـبح أقل والتوازن لا يكسون في الاوضـاع الثابتـة فقط ، وانمـا في اثتـاء الحركـة وبعد

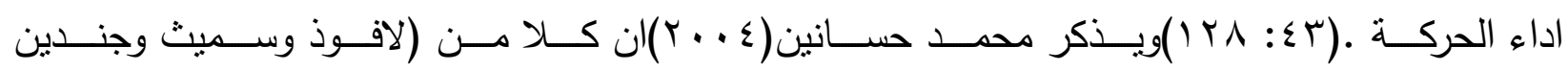
وجاريسـون) اثتبـوا ان مـن اهـم صـفات التـوازن انـه يتحسـن بالتـدريب وان هـذا المكـون يتطـور بصـورة ملموسـة كمـا ان تحسـين هـذة الصـفة لـدى اللاعبـات تـتم عـن طربـق بـرامج التدريبيـة المنتظمـة ضـمن

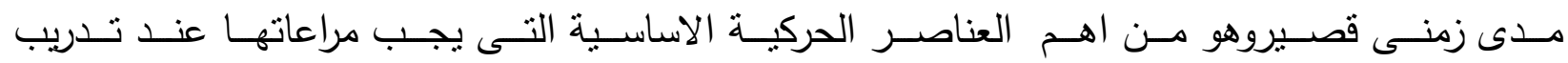

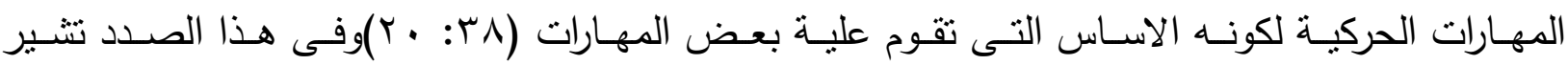




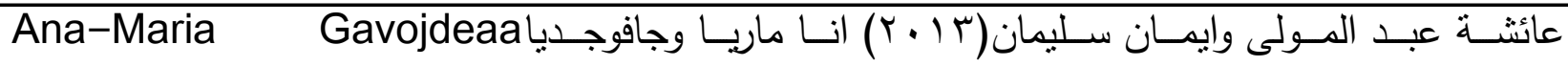

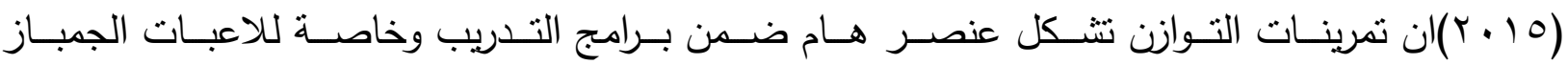

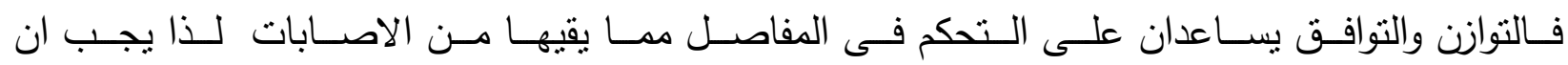
يتضــن البرنـامج تمرينـات للتـوازن علىى قدم واحـدة لمـا لهـا مـن تـاثير عظـيم علـى تحسـين ثبـات

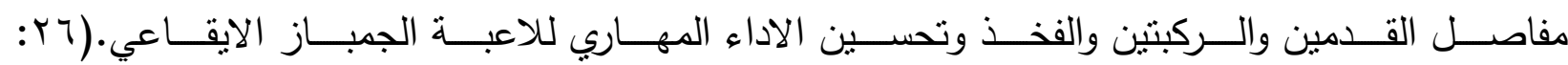
$($ YO : $: 00)(Y \uparrow \varepsilon$

وتعتمــ رياضــة الجمبـاز الايقـاعي اعتمـادا كبيـرا على الادوات المســاعدة نظـر لاحتـواء هـذة الرياضــة على مجموعـة مـن المهـارات الصـعبة المعقدة التـي تتطلـب دقـة وانسـيابية في الاداء الحركي

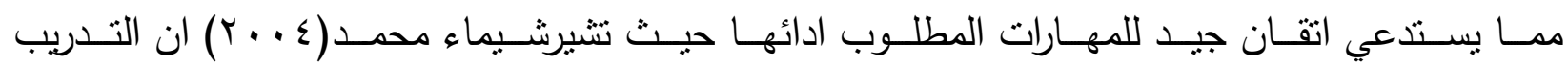
باسـتخدام الادوات المسـاعدة لهـا عامـل كبيـر اذا اسـتخدمت بعنايـة علـى انجـاز المهـارات الاساسـية

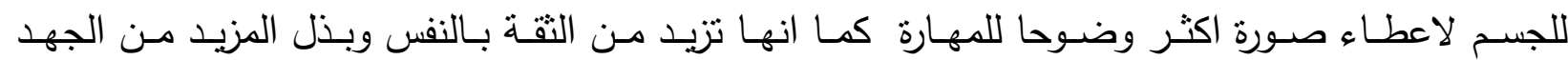

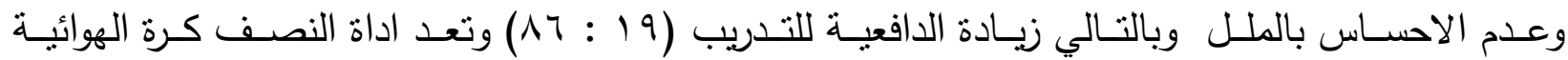
(BOSUBall)

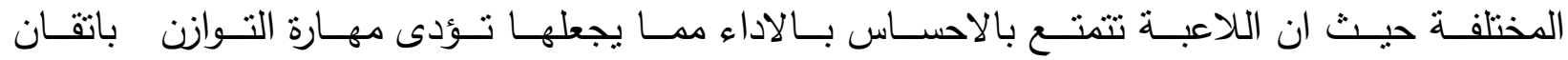

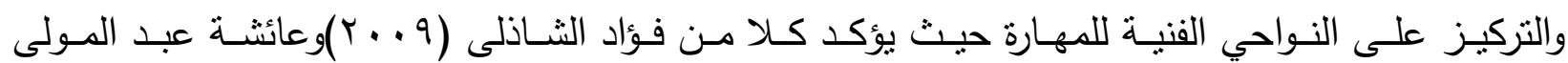

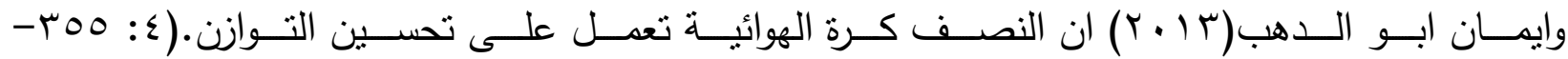
. $(\vee \leqslant)($ Y T : YT $)($ r०T

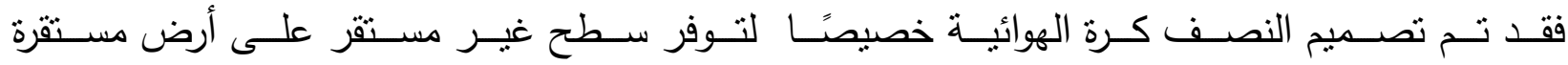
لتحسـين الاسـتقرار لـيس فقط فـي حـين يحـافظ المسـتخدم وضــع مسـتقيم، ولكـن أيضــا عنــما يكـون المسـتخدم في وضـع أفقي ، كمـا انهـا تسـاعد الاعبـات علىى اخـذ الوضـع الصـحيح للجسـم و للـراس

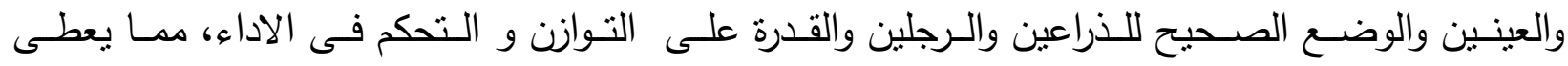

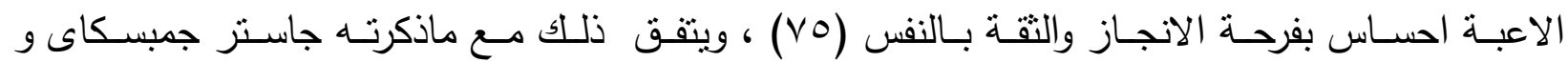

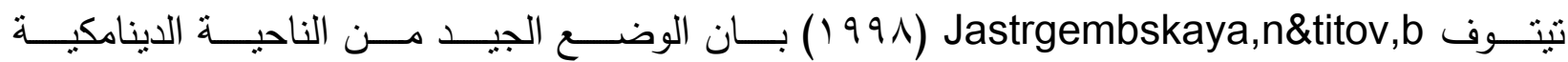

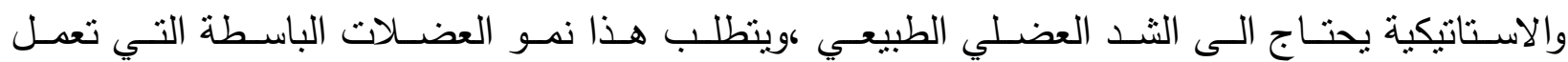

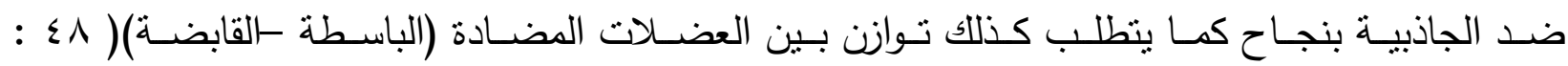

split without تعتبر مهارة الميـزان الجـانبي مـع ميـل الجذع جانبـا في المسـتوى الأفقىى hand support and trunk side horizontal جمـل الجمبـاز الإيقـاعي فـي البطـولات الدوليـة والمحليـة للجمبـاز الإيقـاعي ، ويتطلـب أداءهــا الدقـة 


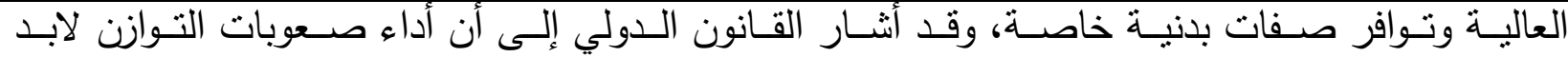

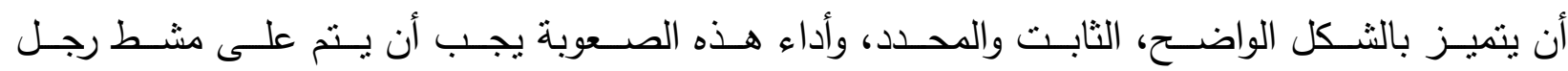

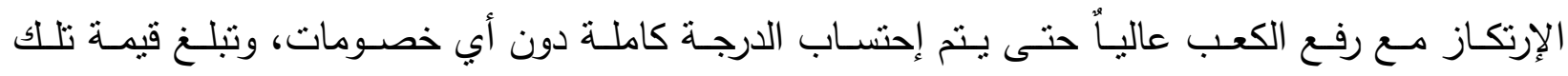

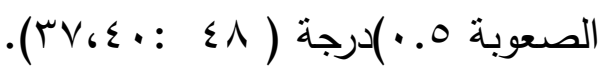
وتـدخل هــذه المهـارة أيضــا ضــمن مهـارات الـدورانات بالإرتنكـاز ولهـا أســتخدامأت أخـرى فـي التوازنــات المركبـة ويكثـر أســتخدامها فـي تكوينـات الجمـل الحركيـة بصــور مختلفــة غيـر الثــكل الأساسـى لهـا، وتضـعها العديـد مـن اللاعبـات في تكـوين جملهـن لمـا لهـا مسن درجـة صـعوبة عاليـة

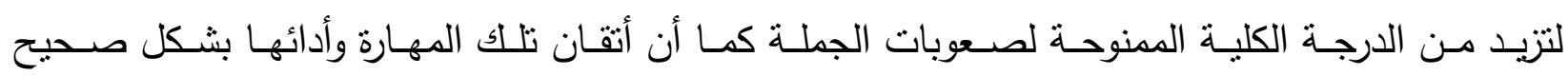
يوضــح مـدى قـدرة اللاعبـة علـى الثبـات والأداء الحركـي ذو المسـتوى العـالي والمــى الواضـح والدقـة في الأداء. ومـن خـلال التحليـل الوصـفى لمهـارة الميـزان الجـانبي مـع ميـل الجـــع جانبـا فـي المسـتوى

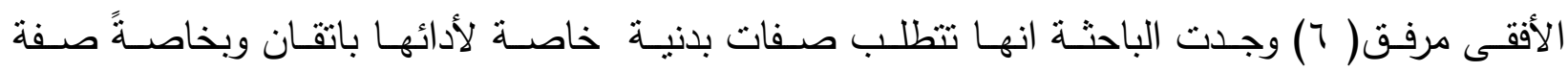

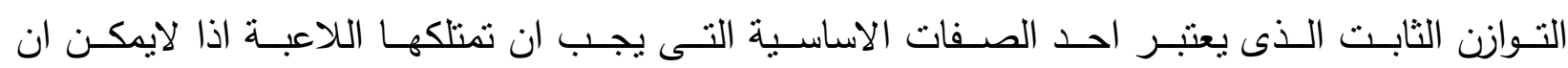
تـؤدي اي عنصـر مـن المجموعـة الاساسـية للجسـم (التوازنـات ،الـدورانات،الوثبات والفجـوات) بصـورة سـليمة اذا لـم تـرتبط خـال ادائهـا بصـفة التوازن ، واكدت ذلك كـلا مـن نعمـات عبـد الـرحمن وماجدة

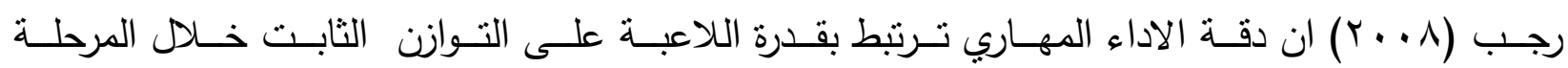
الاعداديـة فـاذا فقدت اللاعبـة القدرة على التـوازن التابـت والحركي فـى المرحلـة الاعداديـة ادى ذلـك

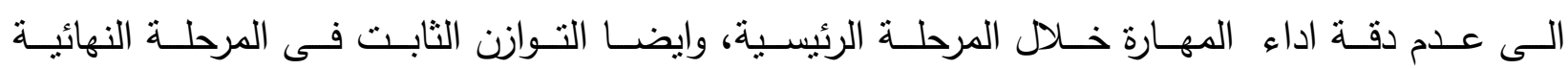

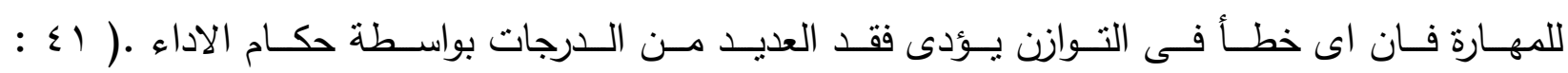

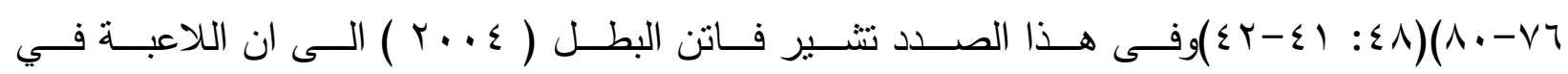

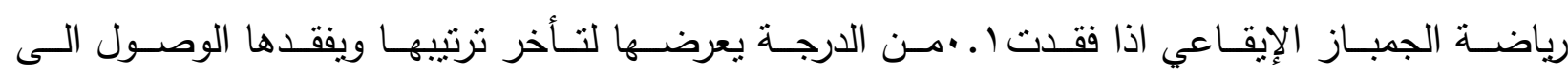

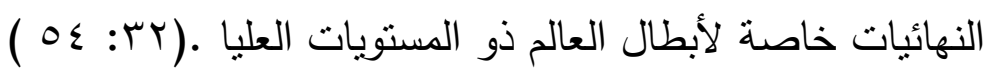

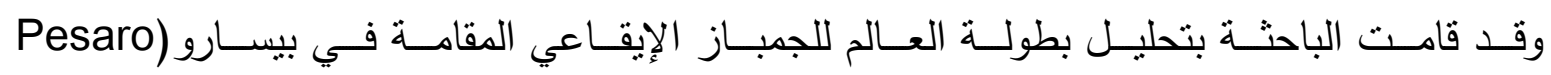

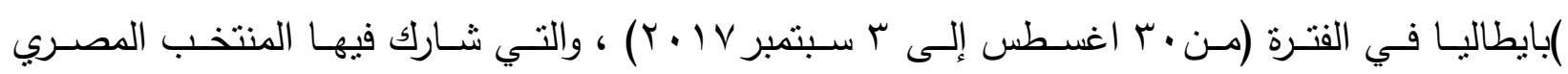

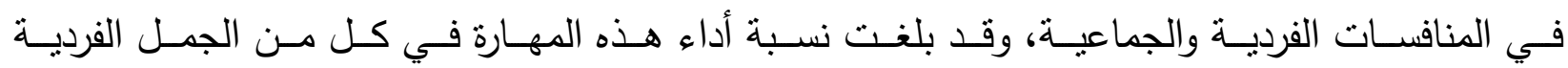
والجماعية من إجمالي عدد الجمل كما يوضح جدول (1) كالآتي: جدول (1) نسبة أداء المهارة قيد البحث

\begin{tabular}{|c|c|c|c|}
\hline \multicolumn{2}{|c|}{ الجمل الجماعية } & \multicolumn{2}{|c|}{ الجمل الفردية } \\
\hline نسبة أداء المهارة & الأداة & نسبة أداء المهارة & الأداة \\
\hline \multirow{2}{*}{$\% \leqslant 0.77$} & \multirow{2}{*}{ شريط } & $\% 0 \leq .1 r$ & طوق \\
\hline & & $\% \circ$. . TI & كرة \\
\hline$\%$ \% ०.० & طوق وصولجان & \%тr & شريط \\
\hline
\end{tabular}




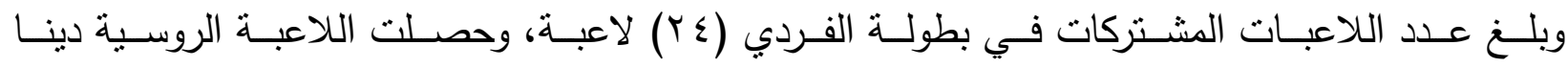

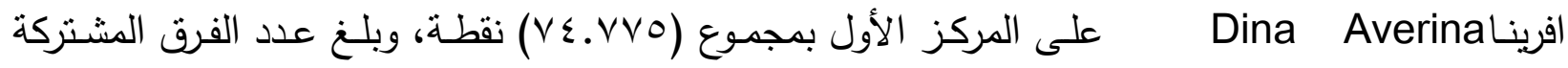

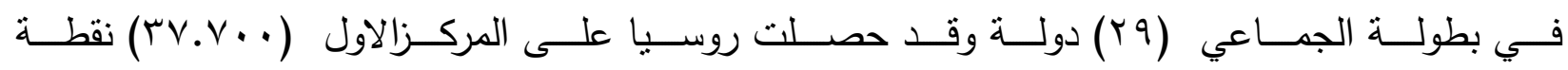

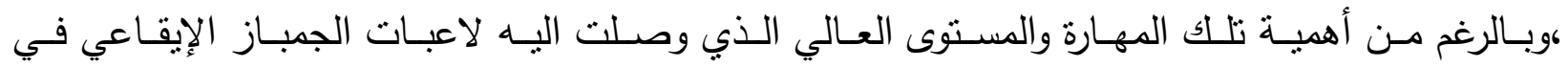

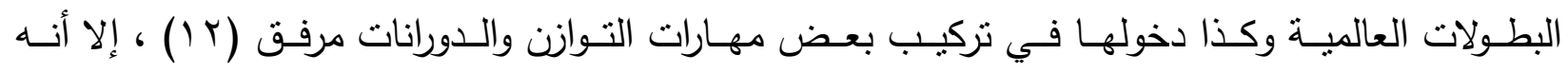

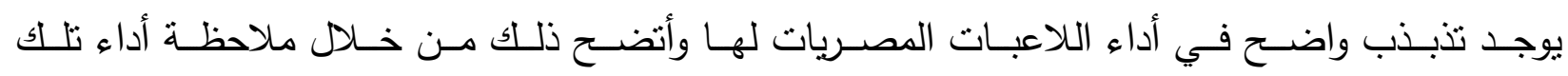

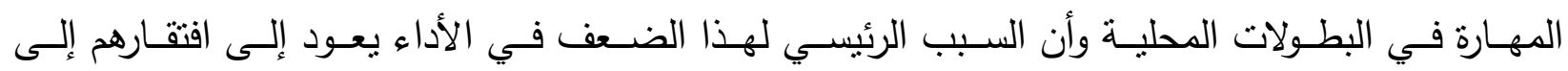

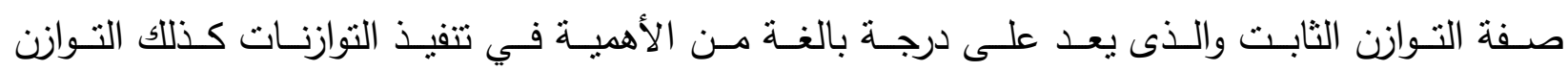

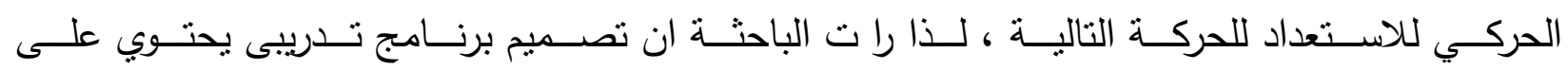

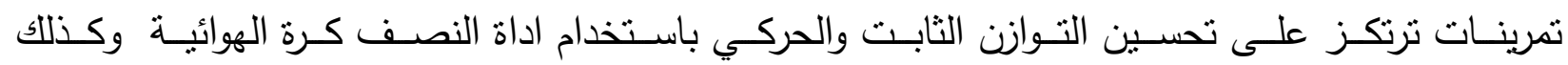

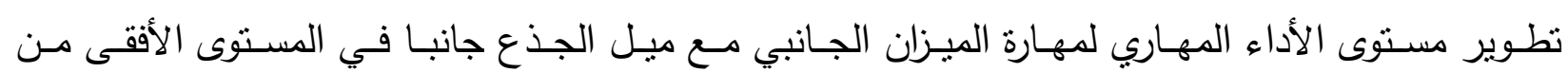

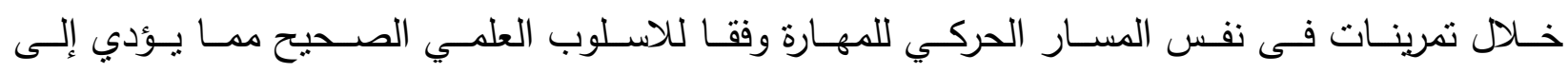

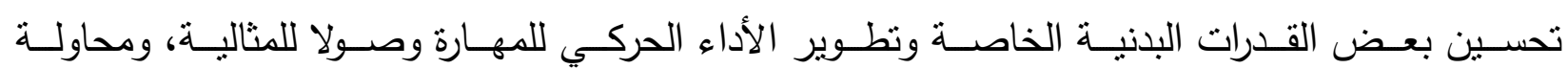

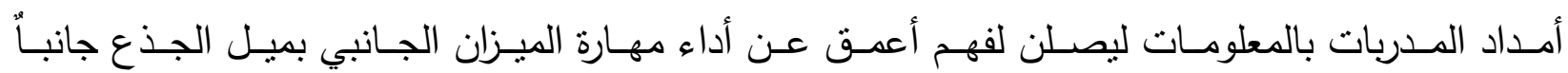

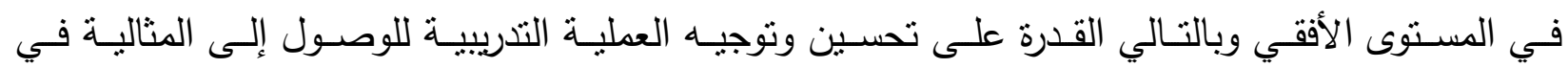
الأداء لتحقيق أفضل الأنجازات الرياضية.

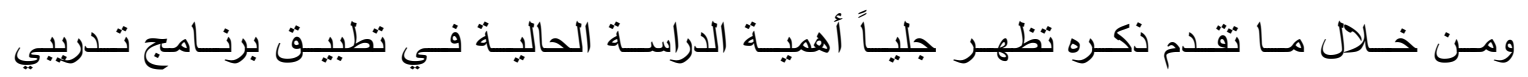

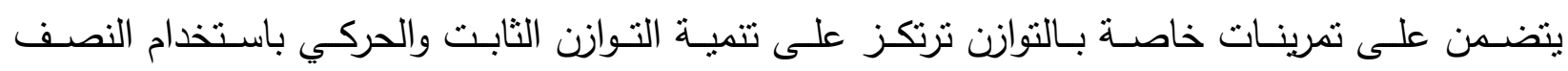

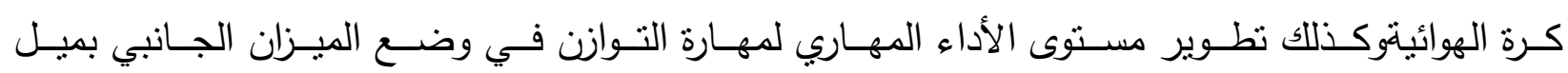
الجذع في المستوى الأفقي من خلال تمرينات فى نفس المسار الحركى للمهارة قيد البحث.

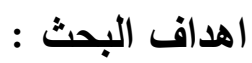

يهـدف هذا البحث الـى تصـيم برنـامج تـدريبي مقترح باسـتخدام تـريبات التـوازن الثابـت والحركي

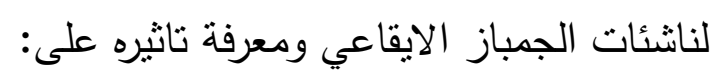
1- تحسين كل من النوازن الثابت والحركي

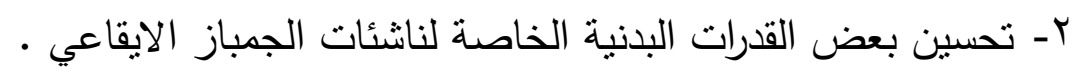

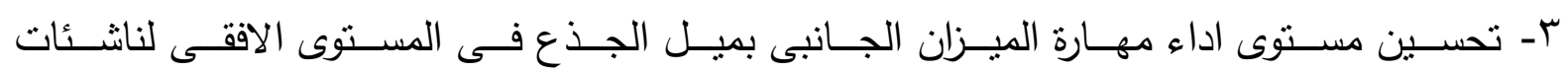

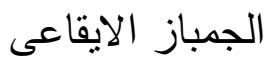

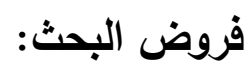
1- توجـد فـروض دالـة احصـائية فـى القياسـين القبلـى والبعـدى لصـالح القيـاس البعـدى فى اختبـارات 
ץ- توجـد فـروض دالـة احصـائية فـى القياسـين القبلى والبعـدى لصـالح القيـاس البعـدى فـى اختبـارات بعض القدرات البدنية الخاصة بالمهارة قيد البحث. ب- توجــ فـروض دالـة احصــائية فـى القياسـين القبلـى والبعـدى لصـالح القبـاس البعـدى فـى مسـتوى الاداء المهاري لمهارة الميزان الجانبى بميل الجذع فى المستوى الافقى ..

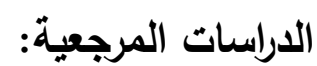

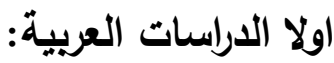

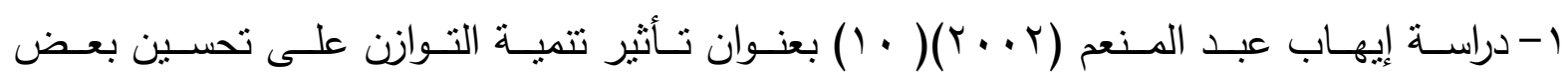
المتغيـرات الكينماتيكيـة للـدورة الهوائيـة الخلفيـة المتكـورة المزدوجـة كنهايـة على جهـاز المتـوازى

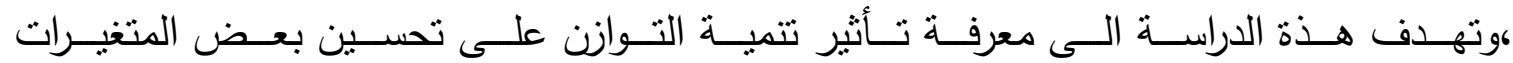

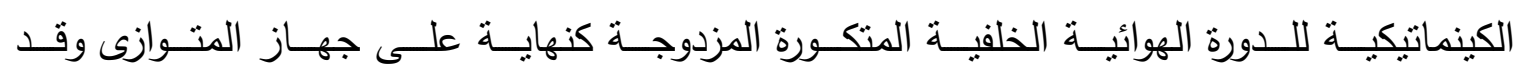

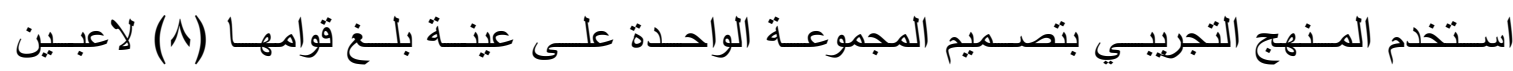

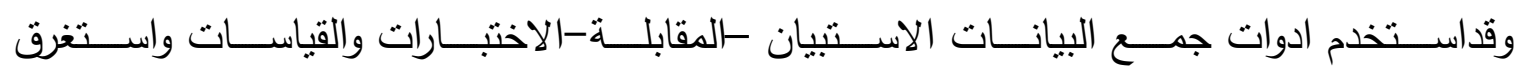
البرنــامج (^)(اســابيع ، وكــان مـن أهـم النتـائج أن تمرينـات التـوازن أدت إلـى تحسـين صــفة التوازن ودرجة مستوى الأداء المهارى

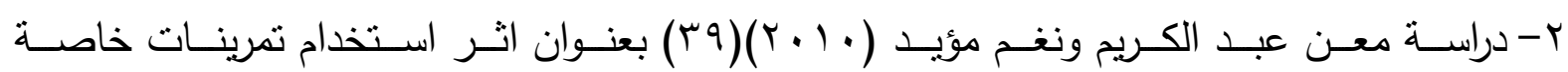

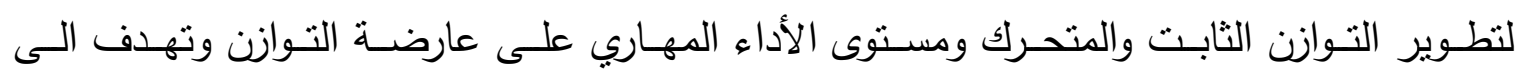
التعـرف علىى اثر اسـتخدام تمرينـات خاصـة لتطـوير التـوازن الثابــ والحركي ومسـتوى الأداء المهـاري علـى عارضــة التـوازن ووقـد اسـتخدم المـنهج التجريبـي بتصـميم المجمـوعتين احـدهم ضـابطة والاخـري تجريبيـة على عينـة مـن طالبـة كليـة تربيـة رياضـية بنـات وقداسـتخدم ادوات

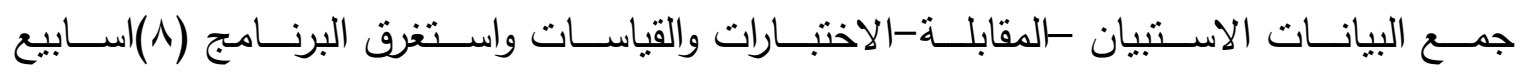
كوكانــت اهــم النتـائج ان البرنـامج التـدريبي المقتـرح ادى الـى تحسـن التـوازن الثابــ والحركي ومستوى الاداء المهاري

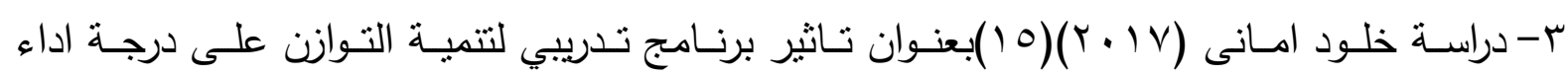
بعـض مهـارات الجمبـاز الايقـاعي لناشـئات وتهـدف الـى التعـرف على تـاثير برنـامج تـدريبي لتتميـة التـوازن على درجـة اداء بعض مهـارات الجمبـاز الايقـاعي لناشـئات وقداسـتخدم المـنهج التجريبـي بتصـميم مجموعـة واحـدة على عينـة قوامهـا(0)لاعبـات تحــ مســوات وقداســتخدم ادوات جمــع البيانـات الاســتبيان -الاختبــارات والقياســات واســتخرق البرنــامج (r ( ) اســبوع وكانــ اهــم النتـائج ادى البرنـامج المقتـرح الـى تحسـين التـوازن الثابـت والحركى كمـا ادى الـى تحسين مستوى الاداء المهارى • 
Leonardo Shigaki- Lucas إباسـة ليوناردو شيجاكى ولوسس ماكيل رابيلو واخرون Maciel Rabello \& other واحدة للاعبات الجمبـاز الايقـاعي وتهدف الى التعـرف على تحليل التوازن على قدم واحدة

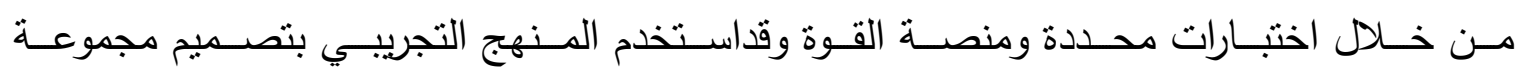

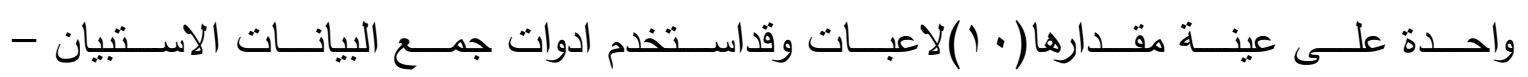

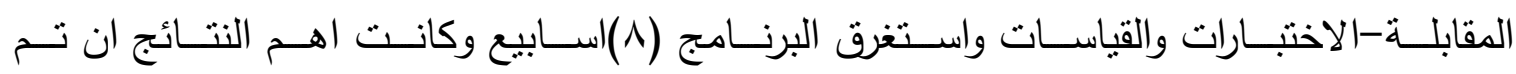

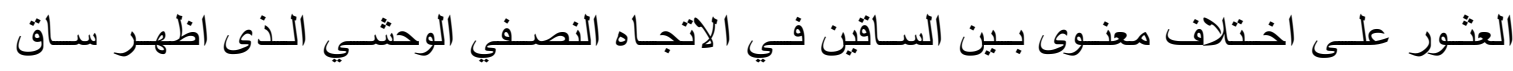

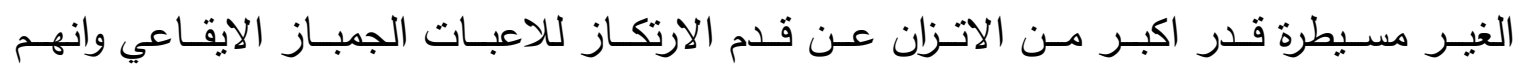

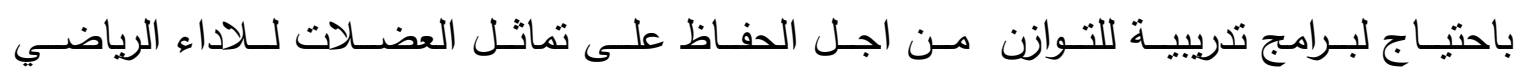
الجيد.

Mavrovouniotis Fotios I, راسـة مـافروفوينيوتيس فوتيـوس وبرويـوس ميلتيـاديس Proios Miltiadis

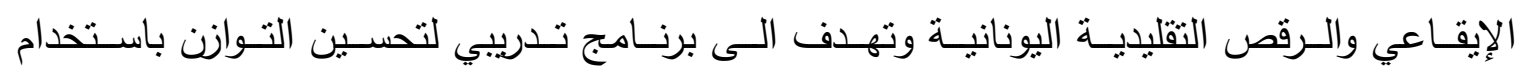

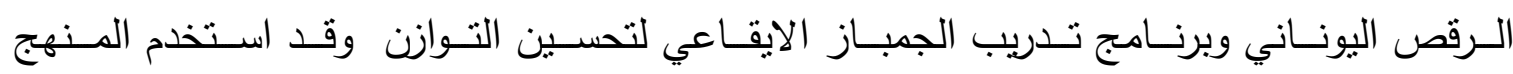

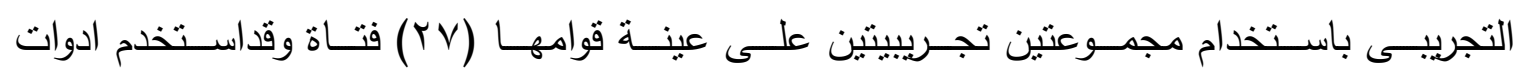

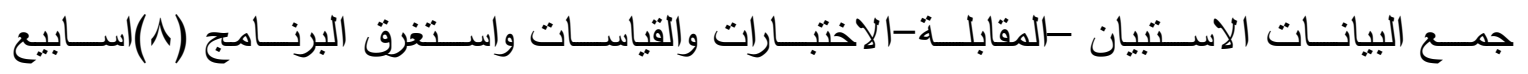

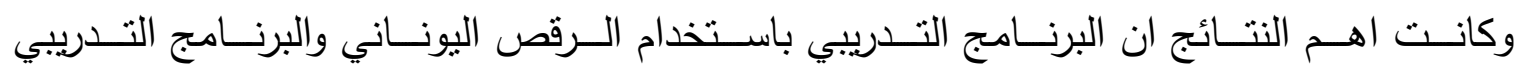
باستخدام الجمباز الايقاعي فى شكل غير تتافسي ادى الى تحسن التوازن الحركي.

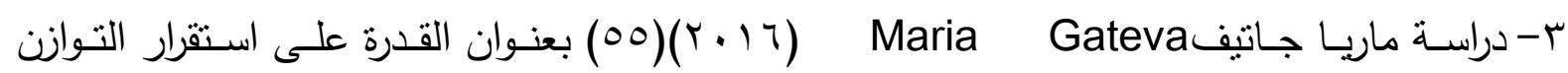

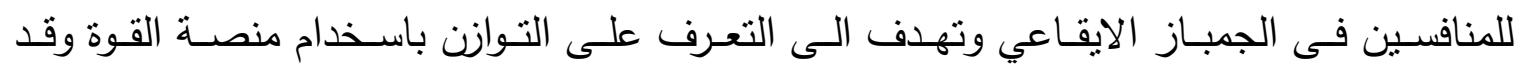

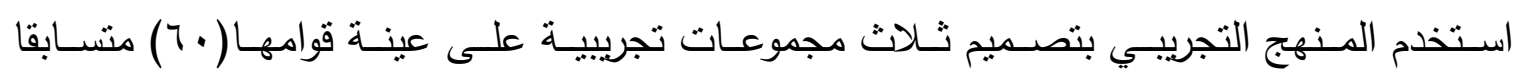

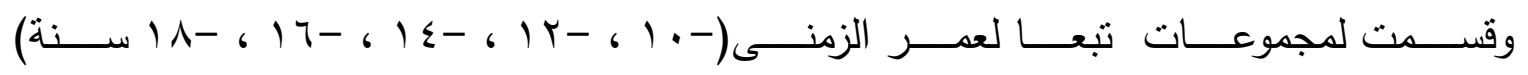

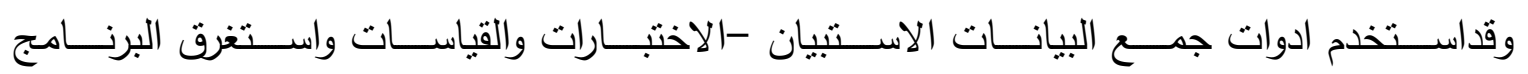

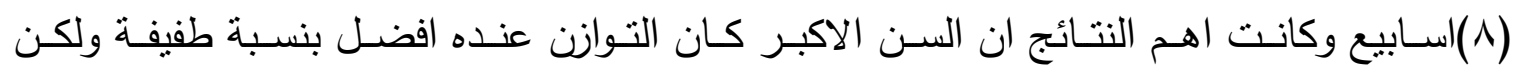
لم يكن هناك تغيرات قياسات منصة القوة. مدى الاستفادة من الداسات المرجعية :

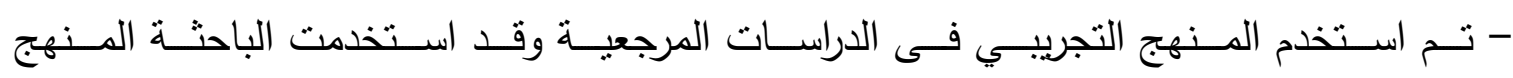
التجريبي لمناسبته لطبيعة البحث. - بعض هـذة الدراسـات طبـق على عينـة مـن طالبـات الكليـة والبعض الاخـر على الناثشئين 


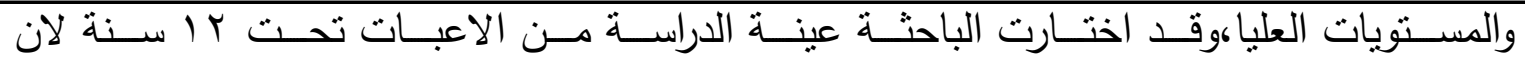

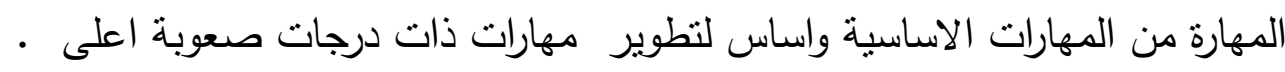

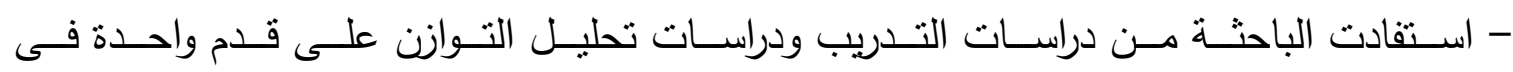

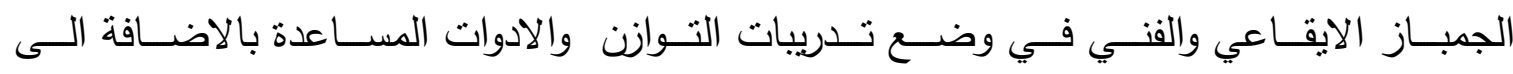

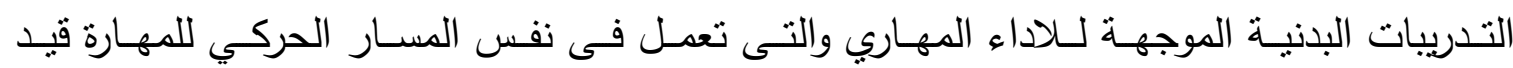

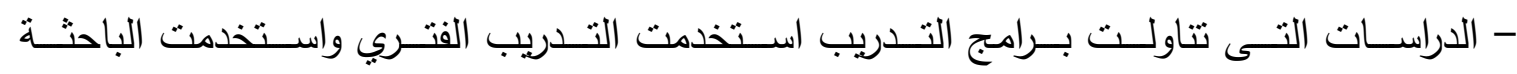
التدريب الفترى لمناسبته لطبيعة البحث.

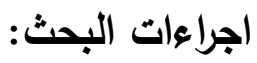
ا -منهج البحث:

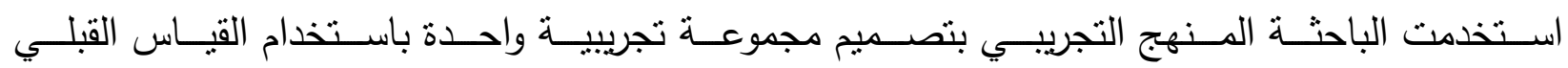
البعدي لملائمته لطبيعة البحث.

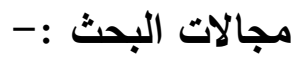

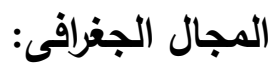

تم تطبيق الدراسة الدراسة الاساسية بنادى سموحة الرياضي بالاسكندرية.

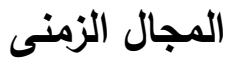

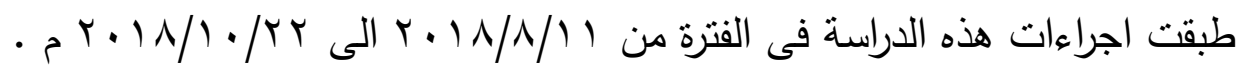

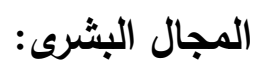

ناشئات الجمباز الايقاعى تحت بال سنة بنادى سموحة الرياضى بالاسكندرية . عينة البحث :

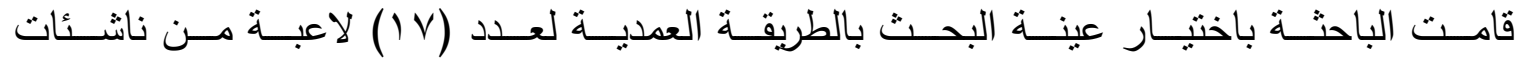

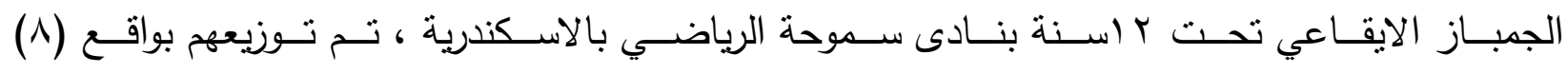

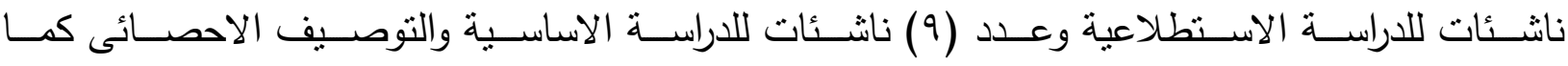

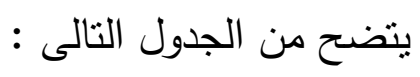
جدول ( r ) التوزيع الاعتدالي لارجات المجموعة التجريبة(قيد البحث)وتجانسها في متغيرات القياسات الاساسية والاختبارات البدنية والقياسات

\begin{tabular}{|c|c|c|c|c|c|c|c|}
\hline \multicolumn{8}{|c|}{ المهارية (ن = lV) } \\
\hline التفرطح & معامل الالتواء & الانعراف & الحسابى & قيمة & قيمة & القياسات & \\
\hline T.YTV- & $. .1 r \cdot-$ & $.01 \leq$ & $1.0 r$ & 11 & 1. & العمر (سنة) & \multirow{4}{*}{ الاساسية } \\
\hline$. V I r-$ &. rVYA- &. .74 & 1 1r..11 & 149 & ITV & الطول (سم) & \\
\hline $1 . \Delta \Gamma \cdot-$ &.$r \wedge$. & $1 . .1 \mathrm{~V}$ & YT.V4 & ru & ro.o & الوزن (كجم) & \\
\hline T.YTV- & $. .1 \% \cdot-$ & $.01 \leqslant$ & $0.0 r$ & 7 & ० & العمر التدريبى (سنة) & \\
\hline
\end{tabular}




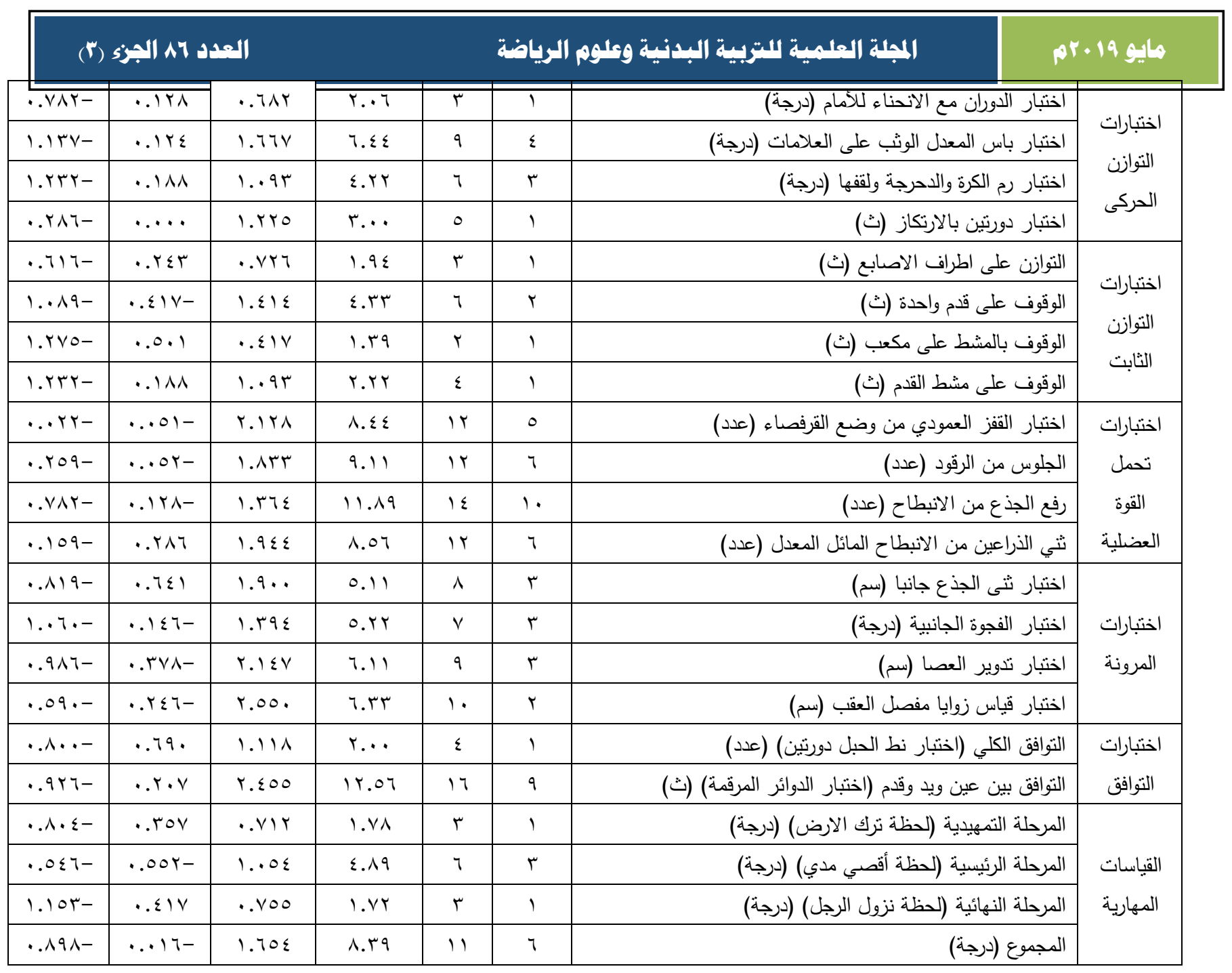

يتضـح من جدول ( r) المتوسط الحســى والاتحراف المعيارى فى القياسـات الأساسية والاختبارات البدنيـة والقياسات المهارية، وجاءت معاملات الإلتواء تقترب من الصفر ومعاملات التفرطح تتحصر ما بين (بد) مما بدل على اعتدالية القيم وتجانس أفراد عينة البحث دن من لناشئات الجمباز الايقاعى قبل تطبيق تطبيق

$$
\begin{aligned}
& \text { الدراسة الاساسية. } \\
& \text { قياسات البحث : } \\
& \text { أولاً :- الاختبارات البدنية : }
\end{aligned}
$$

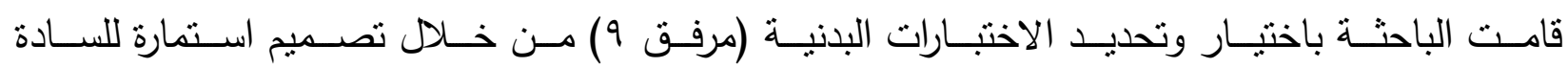

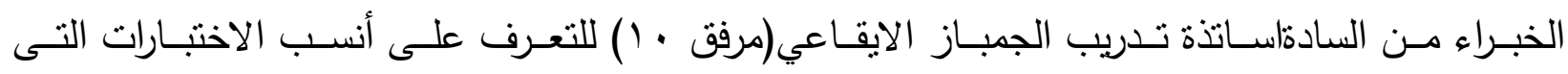

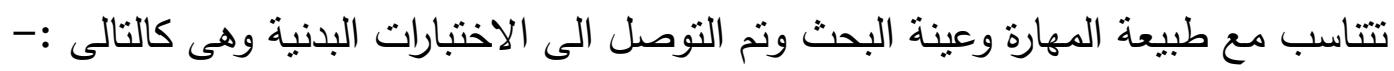

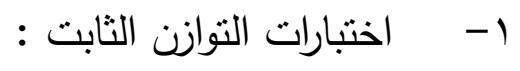

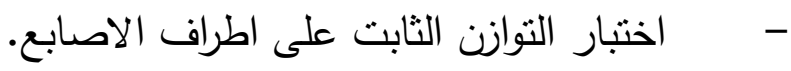

$$
\text { - }
$$

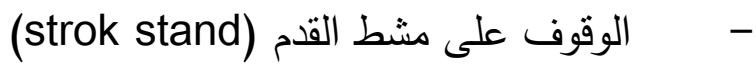




$$
\text { r - - اختبارات التوازن الحركي: }
$$

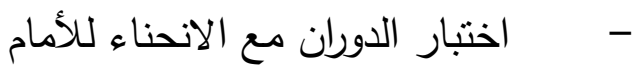

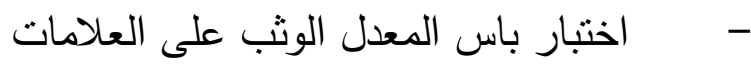

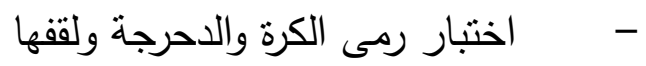

$$
\text { - - - - م- اختبارات دورتين بالارتكاز }
$$

- اختبار القفز العمودي من وضع القرفصاء

$$
\begin{aligned}
& \text { - - الجلوس من الرقود. }
\end{aligned}
$$

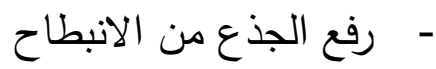

- ـ - ثني الذراعين من الانبطاح المائل المعدل

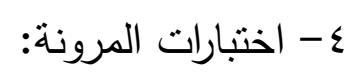

- اختبار ميل الجذع جانبا لتحديد درجة مرونة العمود الفقري.

- اختبار تدوير العصا لتحديد درجة مرونة مفصل الكتق.

- اختبار الفجوة الجانبية لتحديد درجة مرونة مفصل الفخذ.

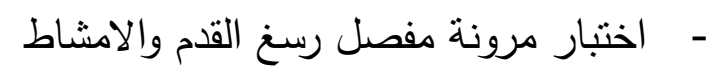

0- - - اختبارات التوافق:

- اختبار نط الحبل لقياس التوافق الكلي للجسم.

- اختبار القفز داخل الدوائر المرقمة لقياس التوافق بين العينين واليدين والرجليين.

$$
\begin{aligned}
& \text { ( ) ( } \\
& \text { ثانياً : القياسات المهارية :- }
\end{aligned}
$$

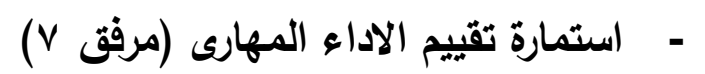

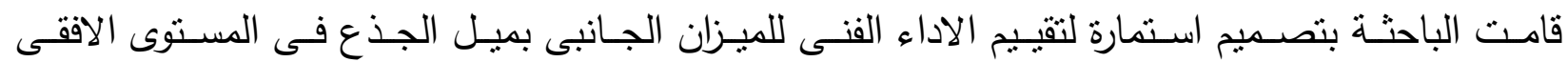

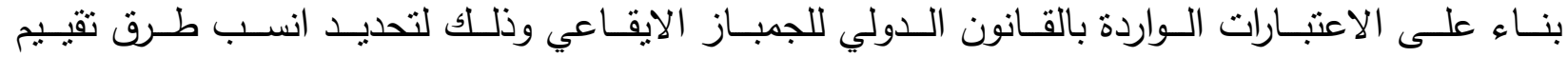

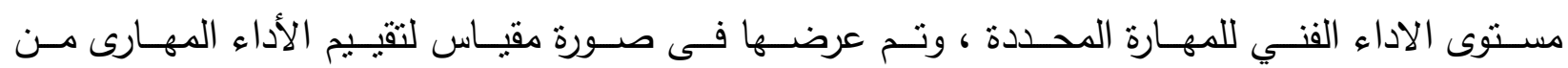

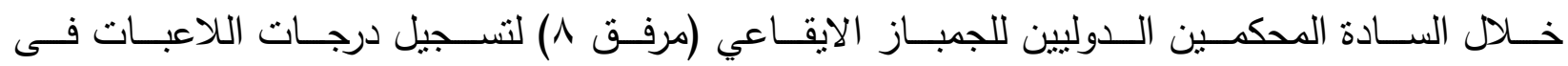

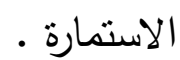

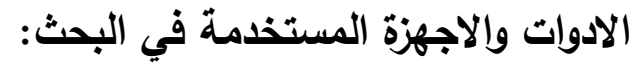

$$
\text { 1- بيزان طبى لقياس الوزن (لاقرب كجم). }
$$

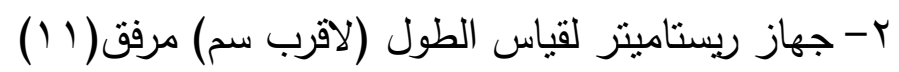

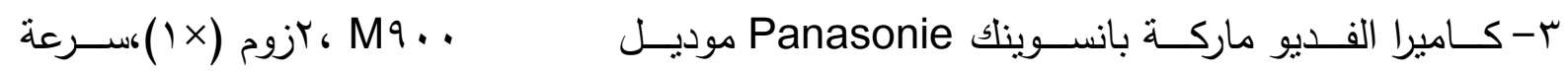




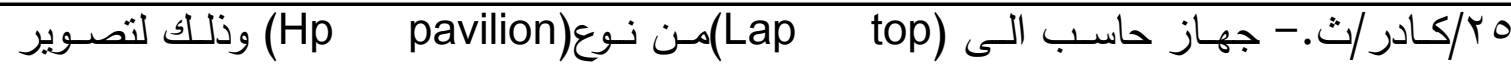

$$
\text { المهارة قيد البحث وتسجيلها على قرص مدمج. }
$$

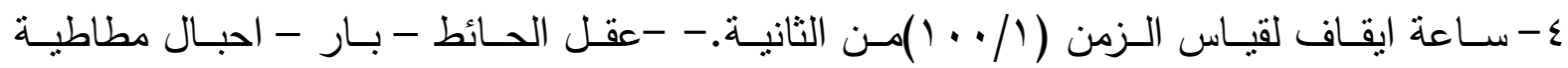

$$
\text { - كرة -مقعد سويدي. جهاز النصف كرة الهوائية مرفق( (1). }
$$

الاراسات الاستطلاعية :

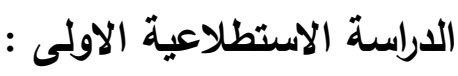

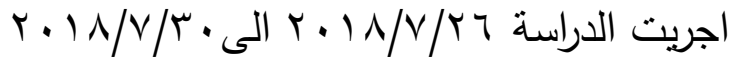

$$
\begin{aligned}
& \text { اجراءات الدراسة والهدف منها: }
\end{aligned}
$$

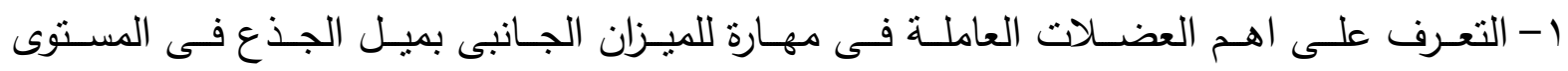

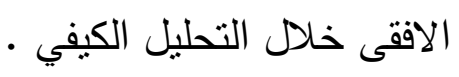

r- التعرف على صلاحية المكان ومدى توافر الادوات الازمة لتنفيذ البرنامج. r- التعرف على مدى صلاحية ادوات القياس ومعرفة كيفية استخدامها الصحيح. نتائج الدراسة:

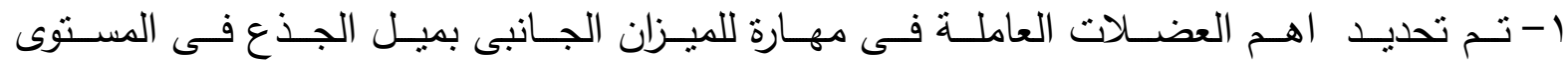

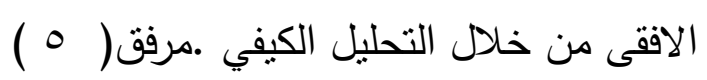

r- تم الثاكد من صلاحية المكان و توافر الادوات الازمة لتنفيذ البرنامج.

\section{الدراسة الاستطلاعية الثانية :}

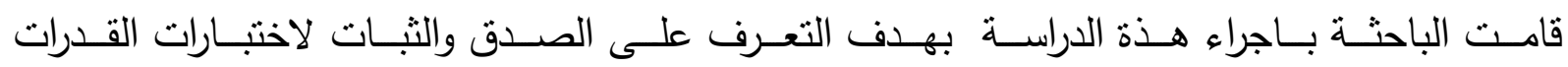

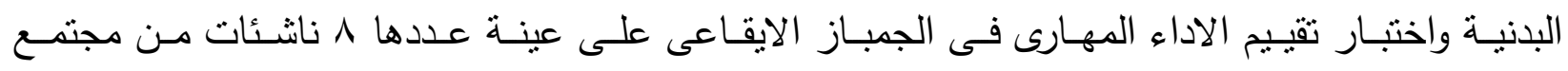

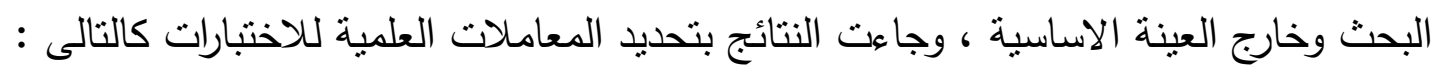

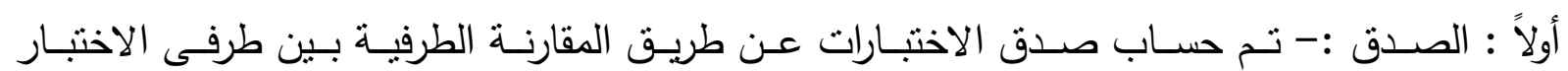

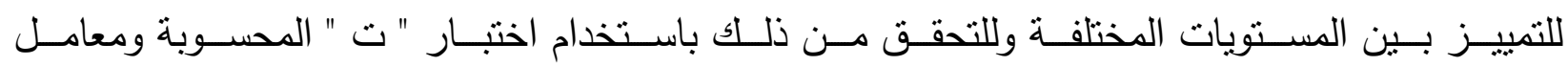

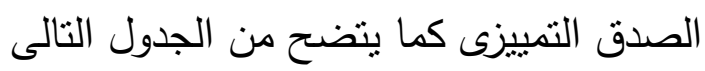

\begin{tabular}{|c|c|c|c|c|c|c|c|}
\hline \multicolumn{8}{|c|}{ لناشئات الجمباز الايقاعي } \\
\hline معامل & قيمة & \multirow{2}{*}{\multicolumn{2}{|c|}{ الطرف الأذنى }} & \multirow{2}{*}{\multicolumn{2}{|c|}{ الطرف الأعلى }} & \multirow{3}{*}{ القياسات } & \multirow{3}{*}{ م } \\
\hline الصدق & "ت" & & & & & & \\
\hline التمييزى & المحسوية & $\varepsilon^{ \pm}$ & 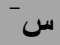 & $\varepsilon^{ \pm}$ & س”- - - - - & & \\
\hline
\end{tabular}

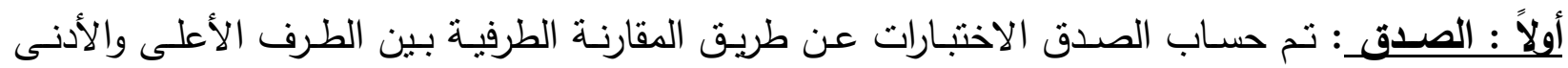

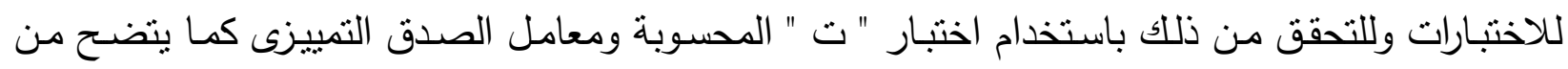

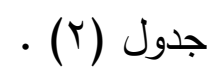

جدول ( ب) المتوسط الحسابى والإنحراف المعيارى وقيمة " ت " المحسوية ومعامل الصدق التمييزى بين الطرف الأعلى والأدنى فى التوازن الحركى 


\begin{tabular}{|c|c|c|c|c|c|c|c|c|}
\hline \multicolumn{4}{|c|}{ 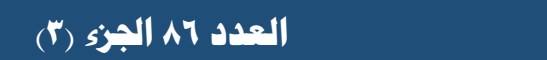 } & \multicolumn{3}{|c|}{ لالبشة الملمية للتزبية البدنية وعلوم الرياضة } & \multicolumn{2}{|c|}{ pr. 19 يليو } \\
\hline. . Aro & $* r .01$ & 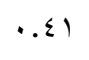 & 1.0 & $\because \sum \wedge$ & r.tr & حناء للأمام (درجة) & اختبار & 1 \\
\hline. $.9 \cdot 0$ & $* * 0 . r$. &.$\wedge r$ & $0 . .$. & $\cdot . \wedge r$ & ^... & تب على العلامات (درجة) & 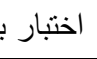 & r \\
\hline. .911 & $* * 0.77$ & .0 & r.ro & $\therefore$. & $0 . r_{0}$ & جة ولقفها (درجة) & 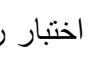 & r \\
\hline. vo. & $* \curlyvee . \vee \wedge$ &. .0 & r.ro & $\cdot .97$ & r.vo & ز (ث) & 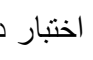 & $\varepsilon$ \\
\hline
\end{tabular}

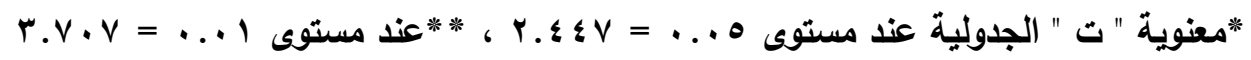
يتضـح من جدول (r) وجود فروق ذات دلالة احصـائية فى قيمة "ت" المحسوبة بين المجموعة المميزة والغير مميزة فى اختبـارات التوازن الحركى ، وتراوحت قيم معامـل الصـدق التمييزى مـا بين ( • v . . : 1 ( 1 ـ • ) وهى قيم مرتفعة مما يؤكد صدق الاختبارات والقدرة على التمبيز بين المستويات المختلفة لناشئات الجمباز الايقاعي قبل تطبيق الدراسة الاساسية . جدول ( ع ) المتوسط الحسابى والإنحراف المعيارى وقيمة " ت " المحسوية ومعامل الصدق التمييزى بين الطرف الأعلى والأدنى فى التوازن الثابت لناشئات الجمباز الايقاعي

\begin{tabular}{|c|c|c|c|c|c|c|c|}
\hline \multirow{2}{*}{ التمدق } & \multirow{2}{*}{ "تلقة } & \multicolumn{2}{|c|}{ الطرف الأدنى } & \multicolumn{2}{|c|}{ الطرف الأعلى } & \multirow[t]{2}{*}{ القياسات } & \multirow[t]{2}{*}{ م } \\
\hline & & $\varepsilon^{ \pm}$ & س- - - س & $\varepsilon^{ \pm}$ & س- - س & & \\
\hline..$\vee 99$ & *r.Yo &. $.2 \wedge$ & $1.7 \pi$ & .0 & r.vo & النوازن على اطراف الاصابع (ث) & 1 \\
\hline. .191 & $* * \ldots$ &. .01 & r.o. &.$\Delta r$ & $0 . .$. & الوقوف على قدم واحدة (ث) & r \\
\hline..$v V$. & $* r .90$ & .ro & $1.1 \pi$ & 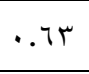 & r.ir & الوقوف بالمشط على مكعب (ث) & $r$ \\
\hline.$\vee \vee r q$ & $*$ *Y.T & .0 & 1.20 &..$\wedge r$ & $r \ldots$ & الوقوف على مشط القدم (ث) & $\varepsilon$ \\
\hline
\end{tabular}

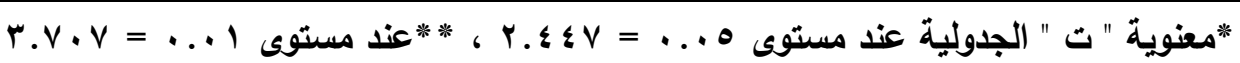
يتضـح من جدول (ع) وجود فروق ذات دلالة احصـئية فى قيمة "ت" المحسوبة بين المجموعة المميزة

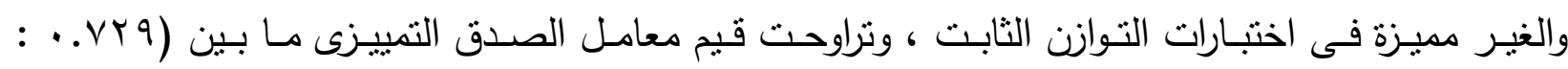
191 ـ • ) وهى قيم مرتقعة مما يؤكد صدق الاختبارات والقدرة على التمبيز بين المستويات المختلفة لناشئات الجمباز الايقاعي قبل تطبيق الدراسة الاساسية .

جدول ( •) المتوسط الحسابى والإنحراف المعيارى وقيمة " ت " المحسوية ومعامل الصدق التمييزى بين الطرف الأعلى والأدنى فى تحمل القوة

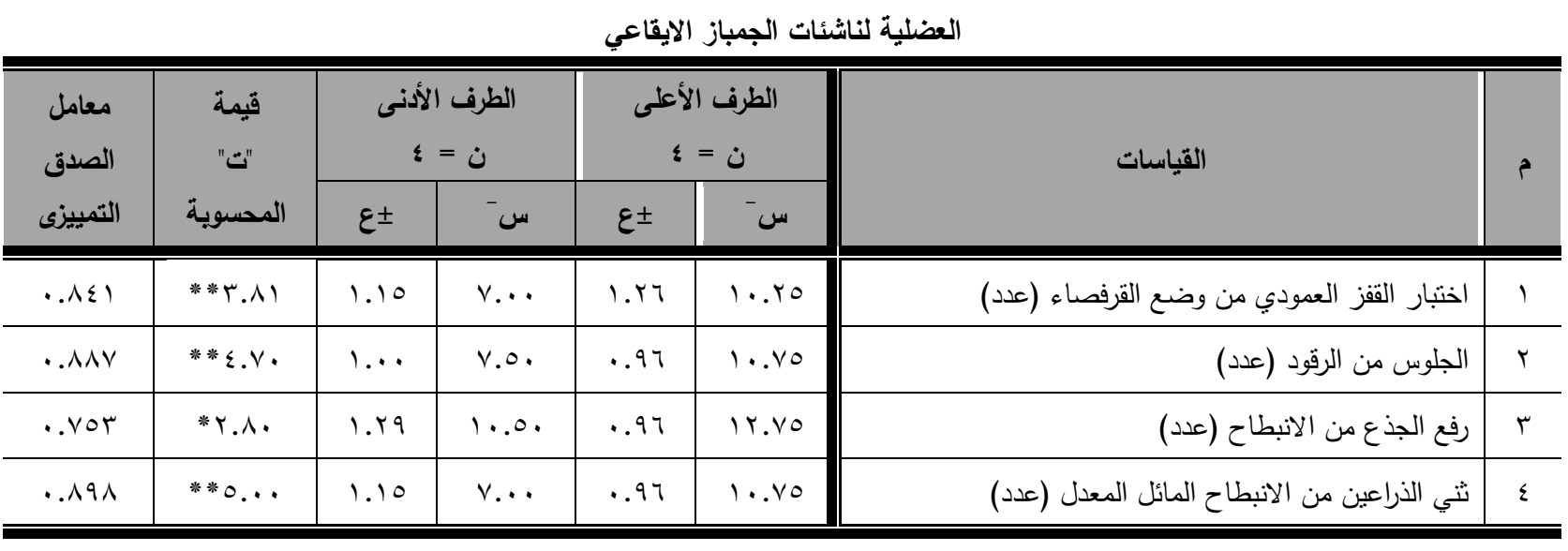

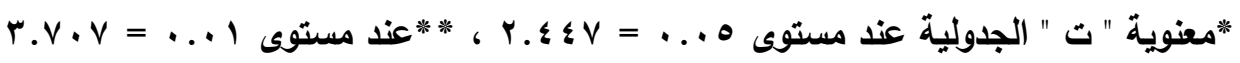


يتضـح من جدول (0) وجود فروق ذات دلالة احصـائية فى قيمة "ت" المحسوبة بين المجموعة المميزة والغير مميزة فى اختبارات تحمل القوة العضلية ، وتراوحت قيم معامل الصدق التمبيزى ما بين (سه . . : . 191 ـ • ) وهى قيم مرتفعة مما يؤكد صدق الاختبارات والقدرة على التمبيز بين المستويات المختلفة لناشئات الجمباز الايقاعي قبل تطبيق الدراسة الاساسية . جدول ( 7) المتوسط الحسابى والإنحراف المعيارى وقيمة " ت " المحسوية ومعامل الصدق التمييزى بين الطرف الأعلى والأدنى فى المرونة والتوافق لناشئات الجمباز الايقاعي

\begin{tabular}{|c|c|c|c|c|c|c|c|}
\hline \multirow{2}{*}{ التمعييزى } & \multirow{2}{*}{ "قات" } & \multicolumn{2}{|c|}{ الطرف الأدنى } & \multicolumn{2}{|c|}{ الطرف الأعلى } & \multirow{2}{*}{\multicolumn{2}{|c|}{ 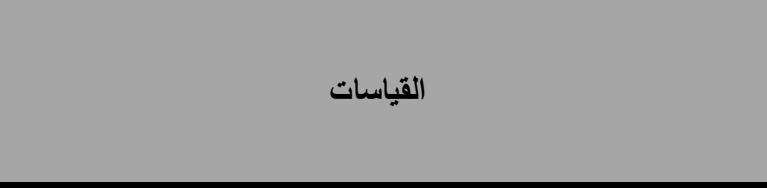 }} \\
\hline & & $\varepsilon^{ \pm}$ & 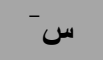 & $\varepsilon^{ \pm}$ & 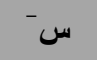 & & \\
\hline..$\vee 94$ & Rtr.tr & $\cdot . \wedge r$ & $\varepsilon \ldots$ & 1.0 & T.Vo & اختبار ثنى الجذع جانبا (سم) & \multirow{4}{*}{ المرونة } \\
\hline$\therefore \vee \wedge \wedge$ & *r.ir &. .01 & «.०. & .97 & 7.10 & اختبار الفجوة الجانبية (درجة) & \\
\hline..$\wedge v T$ & $* * \varepsilon . r q$ & 1.0 & s.ro &.$\Delta r$ & ^... & اختبار تدوير العصا (سم) & \\
\hline..$\wedge V T$ & $* * \varepsilon . r q$ & $1 . \varepsilon 1$ & $\varepsilon \ldots$ & .97 & V.Vo & اختبار قياس زوايا مفصل العقب (سم) & \\
\hline. .117 & $* r . \leqslant \uparrow$ & $\cdot . \wedge r$ & $1 \ldots$ &.$\wedge r$ & r... & التوافق الكلي (اختبار نط الحبل دورتين) (عدد) & \multirow{2}{*}{ التنارات } \\
\hline$\cdot . \wedge \cdot r$ & *r.r. & $1 . v 1$ & ir.vo & 1.14 & $1 . . r_{0}$ & النوافق بين عين ويد وقدم (اختبار الدوائر المرقمة) (ث) & \\
\hline
\end{tabular}

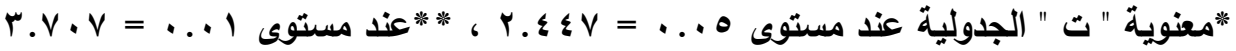
يتضـح من جدول ( آ) وجود فروق ذات دلالة احصائية فى قيمة "ت" المحسوبة بين المجموعة المميزة

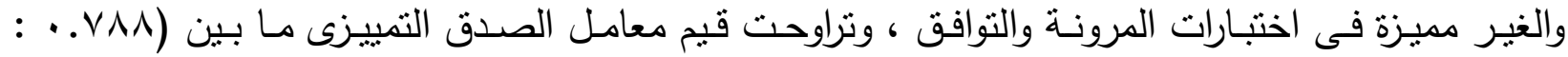
س AV . • ) وهى قيم درتفعة مما يؤكد صدق الاختبارات والقدرة على التمييز بين المستويات المختلفة لناشئات الجمباز الايقاعي قبل تطبيق الدراسة الاساسية . ثانياً : الثبات : تم التحقق من الثبات عن طريق اعادة التطبيق بفاصل زمنى قدرة 10 يوم بين التطبيق الأول واعادة التطبيق ثم حساب قيمة "ت" ومعامل الثبات بين التطبيقين كما يتضح من جدول (؟) . جدول (v) المتوسط الحسابى والإنحراف المعيارى وقيمة " ت " المحسوية ومعامل الثبات بين التطبيق واعادة التطبيق فى التوازن الحركى لناشئات

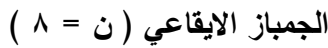

\begin{tabular}{|c|c|c|c|c|c|c|c|}
\hline \multirow{2}{*}{ معامل } & \multirow{2}{*}{ قاتمة } & \multicolumn{2}{|c|}{ اعادة التطبيق } & \multicolumn{2}{|c|}{ التطبيق الأول } & \multirow{2}{*}{ القياسات } & \multirow[b]{2}{*}{ b } \\
\hline & & $\varepsilon^{ \pm}$ & س - & $\varepsilon \pm$ & س- & & \\
\hline$* . \vee \vee \leqslant 0$ & .7 & $1 . Y \wedge$ & r.ro &.$V r$ & r.. & اختبار الدوران مع الانحناء للأمام (درجة) & 1 \\
\hline$* * .90$ & 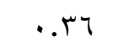 & r.o. & T.ґ^ & $1 . V \mathrm{~V}$ & 7.0 & اختبار باس المعدل الوثب على العلامات (درجة) & r \\
\hline$* . \vee \wedge \wedge$ & $\cdot . \leqslant r$ & $.7 \varepsilon$ & $\varepsilon .1 T$ & 1.17 & S.Yo & اختبار رم الكرة والدحرجة ولققها (درجة) & r \\
\hline$* . \vee \backslash \wedge$ & 1.17 & $1 . r$. & r.7 & $1 . . v$ & r... & اختبار دورتين بالارتكاز (ث) & $\varepsilon$ \\
\hline
\end{tabular}

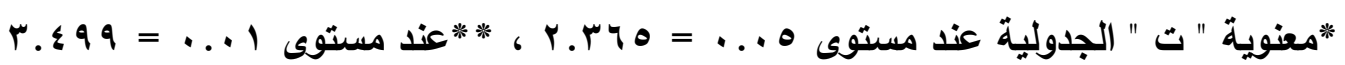




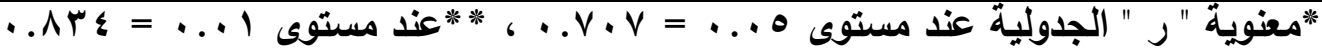

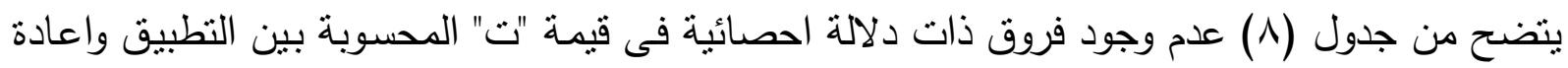
التطبيق فى اختبارات التوازن الحركى ، ووجود دلالة معنوية فى قيم معامل الثبات حيث تراوحت القيم ما بين

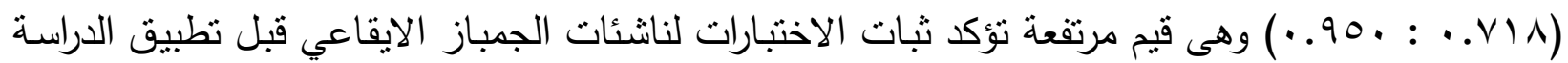

جدول ( 9) المتوسط الحسابى والإنحراف المعيارى وقيمة " ت " المحسوية ومعامل الثبات بين التطبيق واعادة التطبيق فى التوازن الثابت لناشئات

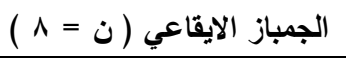

\begin{tabular}{|c|c|c|c|c|c|c|c|}
\hline \multirow{2}{*}{ الثبات "ر" } & \multirow{2}{*}{ "تل" المحسوية } & \multicolumn{2}{|c|}{ اعادة التطبيق } & \multicolumn{2}{|c|}{ التطبيق الأول } & \multirow{2}{*}{ القياسات } & \multirow[b]{2}{*}{ 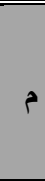 } \\
\hline & & $\varepsilon^{ \pm}$ & 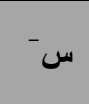 & $\varepsilon^{ \pm}$ & 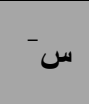 & & \\
\hline$* . . V \Gamma \wedge$ & 1.94 & $.0 \mathrm{r}$ & r.th &. .4 & r..4 & التوازن على اطراف الاصابع (ث) & 1 \\
\hline$* \cdot . \wedge \cdot v$ & $\cdot . \wedge$ & 1.51 & $\varepsilon \ldots$ & $1 . \leqslant 9$ & r.vo & الوقوف على قدم واحدة (ث) & $r$ \\
\hline$* . . v 11$ & 1.94 &. .10 & 1.11 &..$\leq 4$ & 1.0 & الوقوف بالمشط على مكعب (ث) & $r$ \\
\hline$*$. . vol & .00 & .94 & r.o. &. .94 & T.r. & الوقوف على مشط القدم (ث) & $\varepsilon$ \\
\hline
\end{tabular}

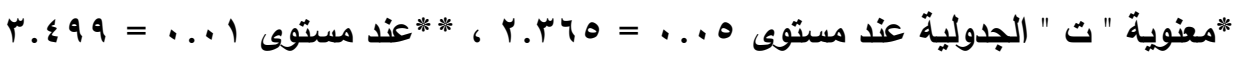

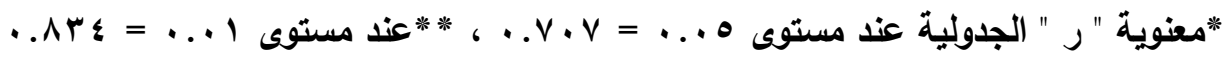
يتضح من جدول (9) عدم وجود فروق ذات دلالة احصائية فى قيمة "ت" المحسوبة بين التطبيق واعادة التطبيق فى اختبارات التوازن الثابت ، ووجود دلالة معنوية فى قيم معامل الثبات حيث تراوحت القيم ما بين

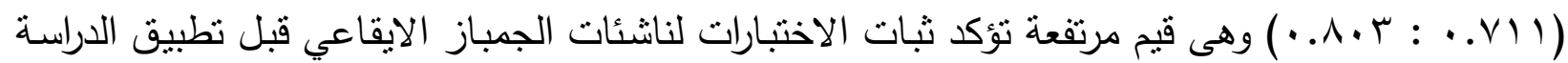

جدول ( 1) المتوسط الحسابى والإنحراف المعيارى وقيمة " ت " المحسوية ومعامل الثبات بين التطبيق واعادة التطبيق فى تحمل القوة العضلية لناشئات الجمباز الايقاعي ( ن = A ) )

\begin{tabular}{|c|c|c|c|c|c|c|c|}
\hline \multirow{2}{*}{ الثبات "ر" } & \multirow{2}{*}{ 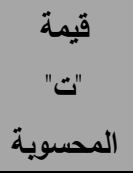 } & \multicolumn{2}{|c|}{ اعادة التطبيق } & \multicolumn{2}{|c|}{ التطبيق الأول } & \multirow{2}{*}{ 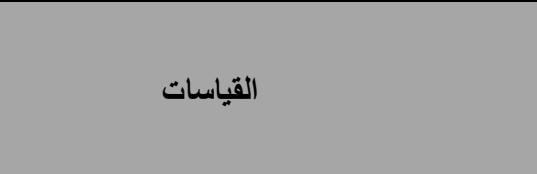 } & \multirow[b]{2}{*}{ b } \\
\hline & & $\varepsilon^{ \pm}$ & 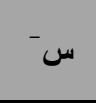 & $\varepsilon^{ \pm}$ & 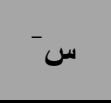 & & \\
\hline$* * .94 \pi$ & $1 . \varepsilon r$ & 1.95 & $9 .$. & r...V & 1.7 & اختبار الققز العمودي من وضع القرفصاء (عدد) & 1 \\
\hline$* . . \vee \leq 9$ &. .01 & 1.97 & $\wedge . \wedge \wedge$ & 1.97 & $9.1 \%$ & الجلوس من الرقود (عدد) & r \\
\hline$* * .90$ & r...o & $1 . r 9$ & $11 . r_{0}$ & 1.7 & 11.74 & رفع الجذع من الانبطاح (عدد) & r \\
\hline$* * .97 \varepsilon$ & $1 . \wedge \mathrm{V}$ & 1.79 & १.५^ & t.rt & $\wedge . \wedge \wedge$ & ثي الذراعين من الانبطاح المائل المعدل (عدد) & $\varepsilon$ \\
\hline
\end{tabular}

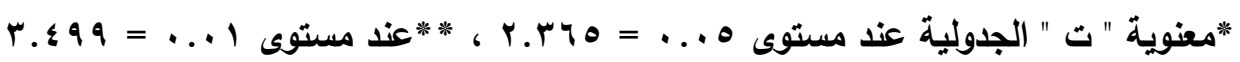

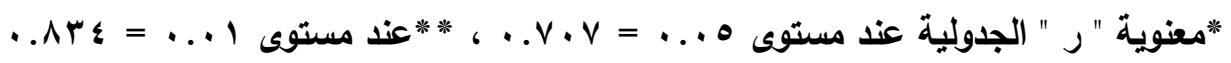
يتضح من جدول (• () عدم وجود فروق ذات دلالة احصائية فى قيمة "ت" المحسوبة بين التطبيق واعادة التطبيق فى اختبارات تحمل القوة العضلية ، ووجود دلالة معنوية فى قيم معامل الثبات حيث تراوحت القيم ما 


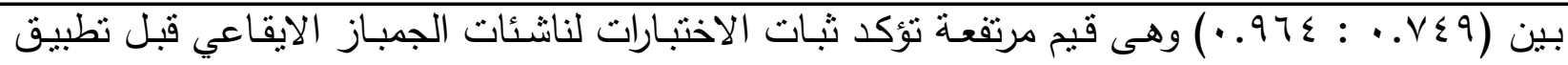
الاراسة الاساسية. جدول ( 11 ) المتوسط الحسابى والإنحراف المعيارى وقيمة " ت " المحسوية ومعامل الثبات بين التطبيق واعادة التطبيق فى المرونة والتوافق

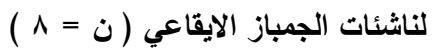

\begin{tabular}{|c|c|c|c|c|c|c|c|}
\hline \multirow{2}{*}{ الثبات "ر" } & \multirow{2}{*}{$\begin{array}{c}\text { قتيمة" } \\
\text { المحسوية }\end{array}$} & \multicolumn{2}{|c|}{ اعادة التطبيق } & \multicolumn{2}{|c|}{ التطبيق الأول } & \multirow{2}{*}{ 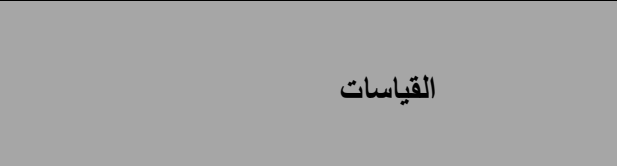 } & \\
\hline & & $\varepsilon^{ \pm}$ & 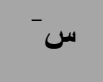 & $\varepsilon^{ \pm}$ & 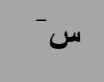 & & \\
\hline$* * .91 \mathrm{r}$ &. .71 & r.rq & $0.7 \pi$ & 1.10 & $0 . r \wedge$ & اختبار ثنى الجذع جانبا (سم) & \multirow{4}{*}{ المرونة المبارات } \\
\hline$* * . . \wedge 79$ & $1 . \varepsilon r$ & $1 . \leqslant 9$ & 0.10 & 1.19 & $0 . \mathrm{r}$ & اختبار الفجوة الجانبية (درجة) & \\
\hline$* * .94$. & $1.0 r$ & tre & $0.7 \pi$ & r.r. & 7.11 & اختبار تدوير العصا (سم) & \\
\hline$* * . .9 \leq r$ & 1.17 & $r .74$ & T.ro & r.r. & 0.11 & اختبار قياس زوايا مفصل العقب (سم) & \\
\hline$* . \vee v r$. & $1.0 r$ & $1 . r \cdot$ & r.o. & 1.5 & r... & التوافق الكلي (اختبار نط الحبل دورتين) (عدد) & 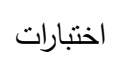 \\
\hline$* * . .9 \leq \wedge$ & $1 . \wedge \mathrm{V}$ & r...V & 11.0. & r.r. & Ir... & التوافق بين عين ويد وقدم (اختبار الدوائر المرقمة) (ث) & 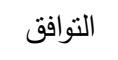 \\
\hline
\end{tabular}

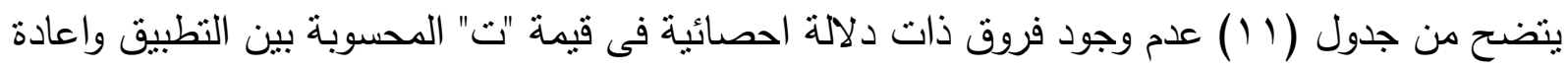

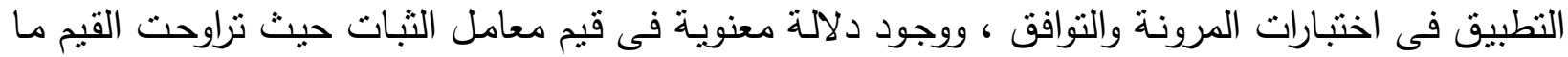

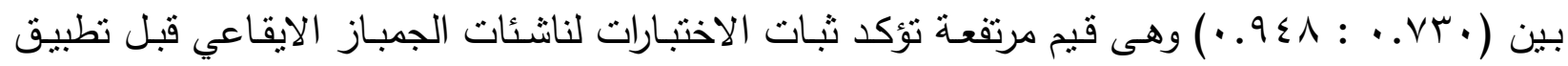
الدراسة الاساسية.

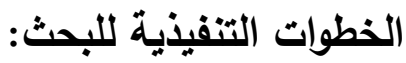
القياسات القبلية :

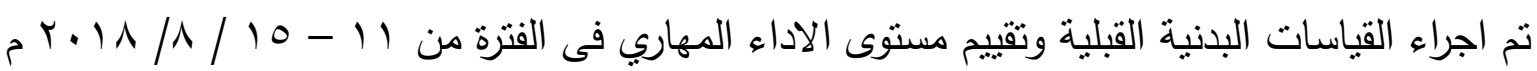
البرنامج التدريبي المقترح : مرفق (10)

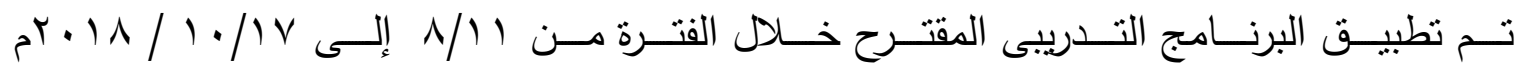
ويهــف الـى تحسـين التـوازن الثابــت والحركـي والقـدرات البدنيـة الخاصــة لتحســين مسـتوى الاداء

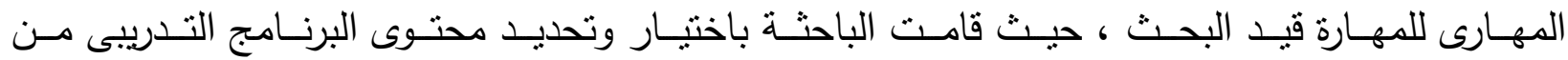

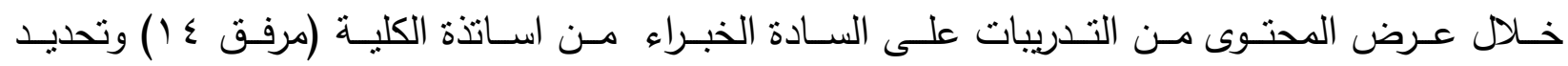

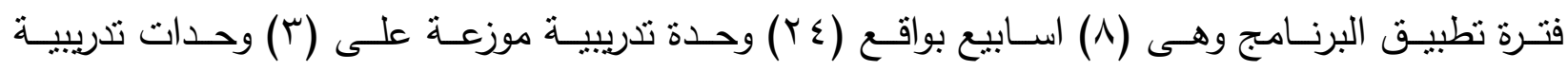

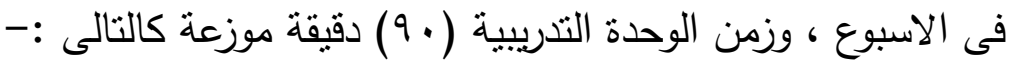

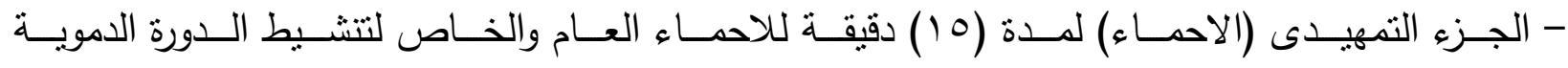
وتهيئة المجموعات العضلية العاملة فى المهارة قيد البحث . 


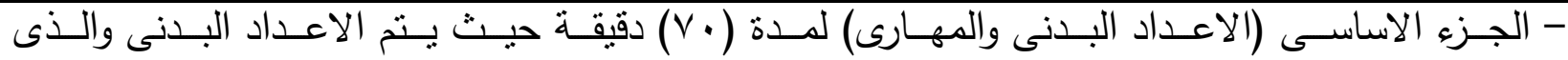
يتضـــن تـدريبات التـوازن الثابـت والحركـي باسـتخدام النصـف الكــرة الهوائيـة ، والتمـرين علـى المهــارة بالطريقة الجزئية والكلية وتصحيح الاخطاء .

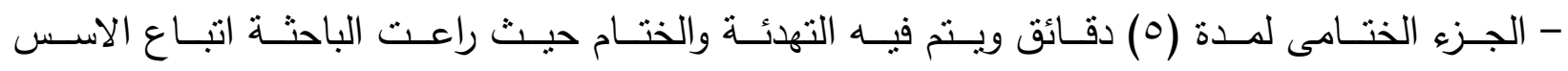
العلمية والواجبات المستهدفة في كل وحدة تدريبية .

\section{اسس وضع البرنامج :}

اتبعــ الباحثـة فـي تصــيم البرنــامج نظامـا يتفـق مــع الاسـس والقواعـد الخاصــة بالتـدريب

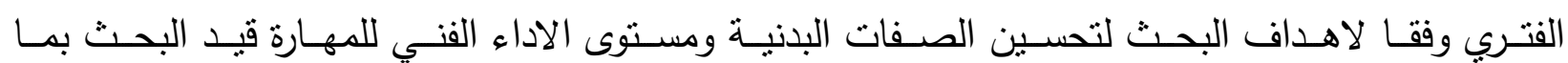
يتتاسب مع المرحلة السنية لعينة البحث كالاتي: - ينفـذ البرنـامج على مجموعـة بحـث واحدة في شـكل وحـدات تدريبيـة يـتم تتفيـذ تمرينـات كـل وحدة في شـكل محطـات منتاليـة باسـتخدام التحميـل الفـردي للاعبـات كـل على حسـب مقدرتـه الوظيفيـة كمـا تم تقنـين التـدريبات المسـتخدمة في البرنـامج التـدريبي مـن خـلال حــل التـدريب حيـث اسـتخدم شـدة المتوسـطة فـى الاداء بنسـبة مـن (00\% : 0 \% \% مـن اقصـى مسـتوى للاعبـة عنـــ اداء التـدربيات بـادوات او بـدون ادوات وذلـك بتحديـد الجرعـة المناسـبة لكـل تمـرين مـن التـدريبات المقترحسة وذلــك بقسـة اقصـى عـدد مـن التكـرار †r مـع تسـجيل الـزمن الـذى اسـتغرقته الاعبـة فـي اداء كـل تمـرين والحمـل الخـاص بـه كمـا تسـجيل زمـن الراحـة البينيـة بـين كـل تمـرين والتمـرين التـالي لـه حيـث كـان

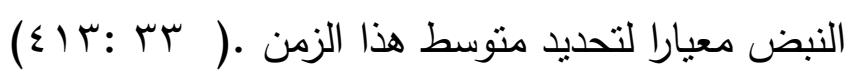
- كـان متوسـط الاداء الفعلـي لكـل تمـرين مـن التـدريبات الموضـوعة يقـدر ب(0 اثل)والراحسة الايجابيـة بــين كـل تمـرين والاخــر (0 اث)،ولانتقــال مـن تمـرين الـى تمـرين التــالى للهوالراحسة البينيــة بـين

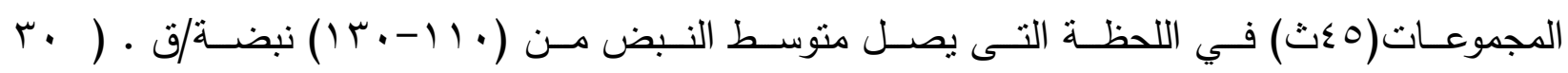
$(1) \varepsilon-1) Y:$ القياسات البعدية :

قامــت الباحثـة بــاجراء القياسـات البعديـة لاختبـارات التـوازن الثابــت والحركـي والقـدرات البدنيـة

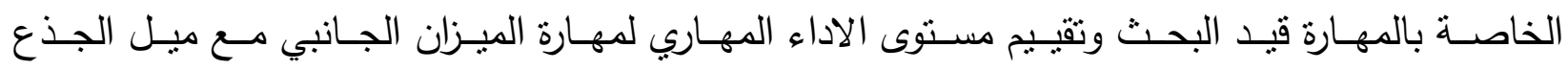

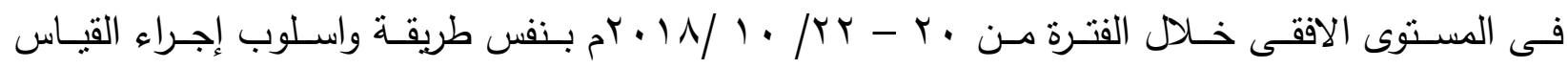
القبلى ثم تتظيم البيانات تمهيدا لمعالجتها احصائياً

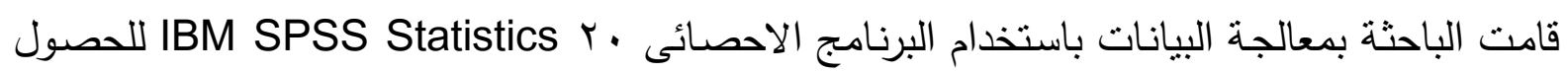
على المعالجات الاحصائية التالية :-

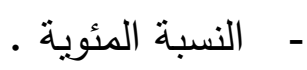




$$
\begin{aligned}
& \text { - } \\
& \text { - }
\end{aligned}
$$

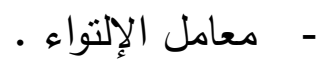

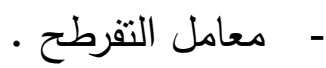

$$
\begin{aligned}
& \text { - معامل الارتباط "ر" لبيرسون • } \\
& \text { - اختبار "ت" للعينات المستقلة . } \\
& \text { - - اختبار "ت" الفروق ل } \\
& \text { - } \\
& \text { عرض ومناقثة النتائج : }
\end{aligned}
$$

\begin{tabular}{|c|c|c|c|c|c|c|c|c|c|c|c|}
\hline \multirow[t]{2}{*}{ 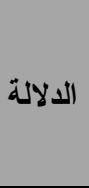 } & \multirow{2}{*}{ قلتمة } & \multirow{2}{*}{$\begin{array}{c}\text { نسبة } \\
\text { \% }\end{array}$} & \multirow{2}{*}{ قتيمة } & \multicolumn{2}{|c|}{ القفرق بين } & \multicolumn{2}{|c|}{ القياس البعدى } & \multicolumn{2}{|c|}{ القياس القبلى } & \multirow[t]{2}{*}{ القياسات } & \multirow[t]{2}{*}{ م } \\
\hline & & & & $\varepsilon^{ \pm}$ & س- & $\varepsilon^{ \pm}$ & 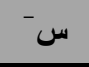 & $\varepsilon^{ \pm}$ & س- - & & \\
\hline مرتفع & r.r. & $\mid r V . \wedge \varepsilon$ & $* * q . \leqslant r$ &. .9 & r.Ar & $1 . r V$ & $\varepsilon . \wedge 9$ &. $.7 \uparrow$ & r.. T & للأمام (درجة) اختـار الـدوران مـع الانحنــاء & 1 \\
\hline مرتفع & $1 . r \wedge$ & $0 \ldots$ & $* * \wedge . \wedge \varepsilon$ & $1 . .9$ & r.rt & r.ro & $9.7 \mathrm{~V}$ & $1.7 \mathrm{~V}$ & $7 . \leqslant \leqslant$ & العلامات (درجة) المبار المعدل الوثب على & r \\
\hline مرتفع & r.vo & 70.19 & $* * 1 \ldots$ &..$\wedge r$ & r.vA &..$\wedge \mathrm{V}$ & $v_{\ldots} .$. & $1 . .9$ & ¿.r & $\begin{array}{r}\text { (درجة) } \\
\text { (ختبار رم الكرة والدحرجة ولقفها }\end{array}$ & r \\
\hline 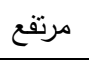 & 1.01 & $1 \ldots$ & $* * 1 \wedge \ldots$ &. .0 & r... & 1.01 & э... & I.r. & r... & اختبار دورتين بالارتكاز (ث) & $\varepsilon$ \\
\hline
\end{tabular}

جدول ( r ا ) المتوسط الحسابى والإنحراف المعيارى ونسبة التحسن وحجم التأثير وقيمة " ت " المحسوية بين القياس القبلى والبعدى فى التوازن

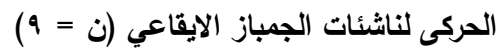

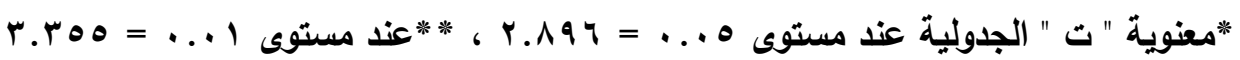

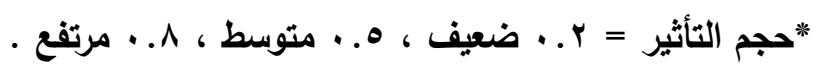

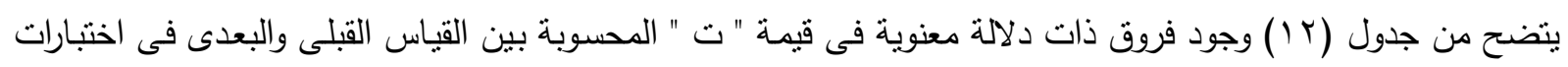

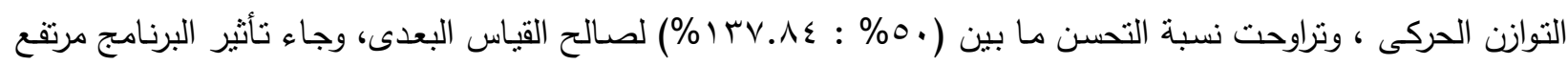

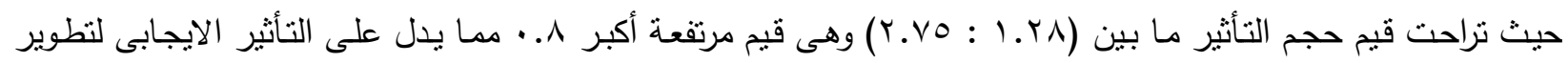
تدريبات النوازن الثابت على القدرات البدنية لناشئات الجمباز الايقاعي.

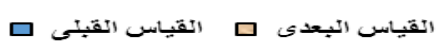

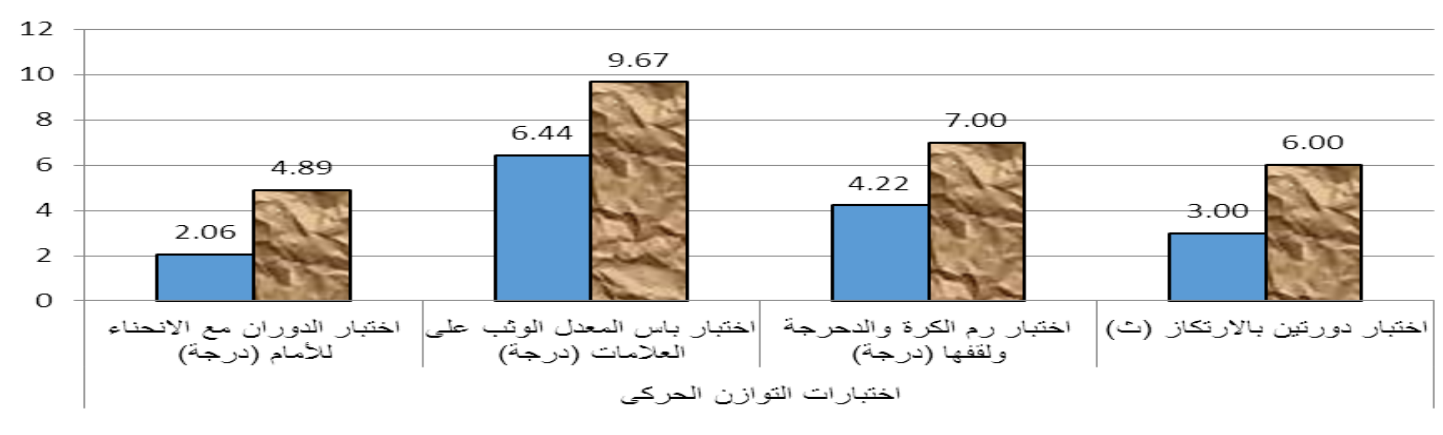




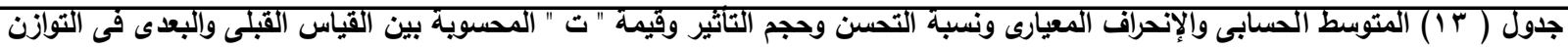

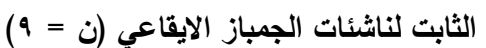

\begin{tabular}{|c|c|c|c|c|c|c|c|c|c|c|c|}
\hline \multirow[t]{2}{*}{ الدلالة الد } & \multirow{2}{*}{ قيمة } & \multirow{2}{*}{$\begin{array}{c}\text { نسبة } \\
\text { \% }\end{array}$} & \multirow{2}{*}{ 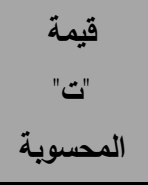 } & \multicolumn{2}{|c|}{ القياسين } & \multicolumn{2}{|c|}{ القياس البعدى } & \multicolumn{2}{|c|}{ القياس القبلى } & \multirow[t]{2}{*}{ القياسات } & \multirow[t]{2}{*}{ p } \\
\hline & & & & $\varepsilon^{ \pm}$ & س- & $\varepsilon^{ \pm}$ & س- & $\varepsilon^{ \pm}$ & س- & & \\
\hline 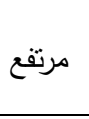 & r.11 & $171.0 \mathrm{~V}$ & **ir..r & $\therefore$. & $r . r \Lambda$ & I.T. & $0 . r Y$ &..$V \mu$ & $1.9 \varepsilon$ & التـوازن على اطـراف الاصــابع & 1 \\
\hline 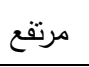 & $1 . \times 1$ & $0 \wedge .9 \vee$ & $* * 1.00$ &.$v r$ & r.07 & $1.0 \leqslant$ & 7.19 & $1 . \varepsilon 1$ & L & الوقوف على قدم واحدة (ث) & r \\
\hline 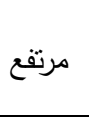 & r..o & $1 \leqslant \wedge .$. & $* * 1 . .0 \mathrm{~V}$ &. .01 & r.. $T$ &..$\wedge \Lambda$ & r. $\varepsilon \varepsilon$ & . $\leqslant$ r & 1.19 & الوقوف بالشـط على مكعب & r \\
\hline 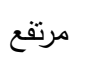 & $1.7 r$ & $1 r \ldots .$. & $* * 11 . .9$ &.$\vee \vee \wedge$ & r.^9 & $1.7 r$ & 0.11 & $1 . .9$ & t.rt & الوقوف على مشط القدم (ث) & $\varepsilon$ \\
\hline
\end{tabular}

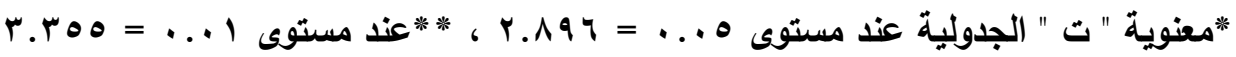

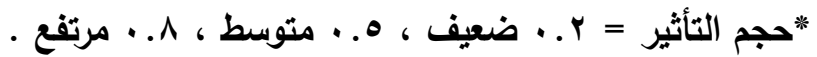

يتضـح من جدول (T ( ) وجـود فروق ذات دلالـة معنويـة فى قيمـة " ت " المحسوبة بين القياس القبلى

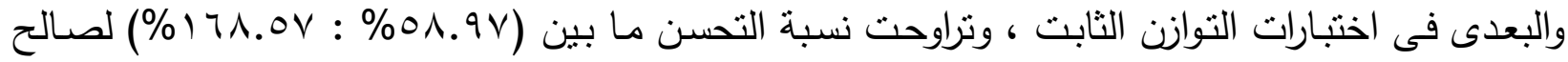

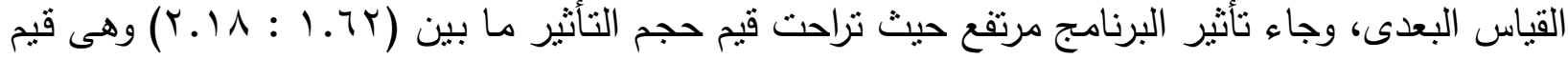
مرتفعة أكبر ^. . مما بدل على التأثير الايجابى لتطوير تدريبات التوازن الثابت على القدرات البدنية لناشئات

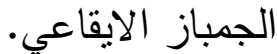

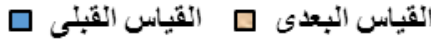

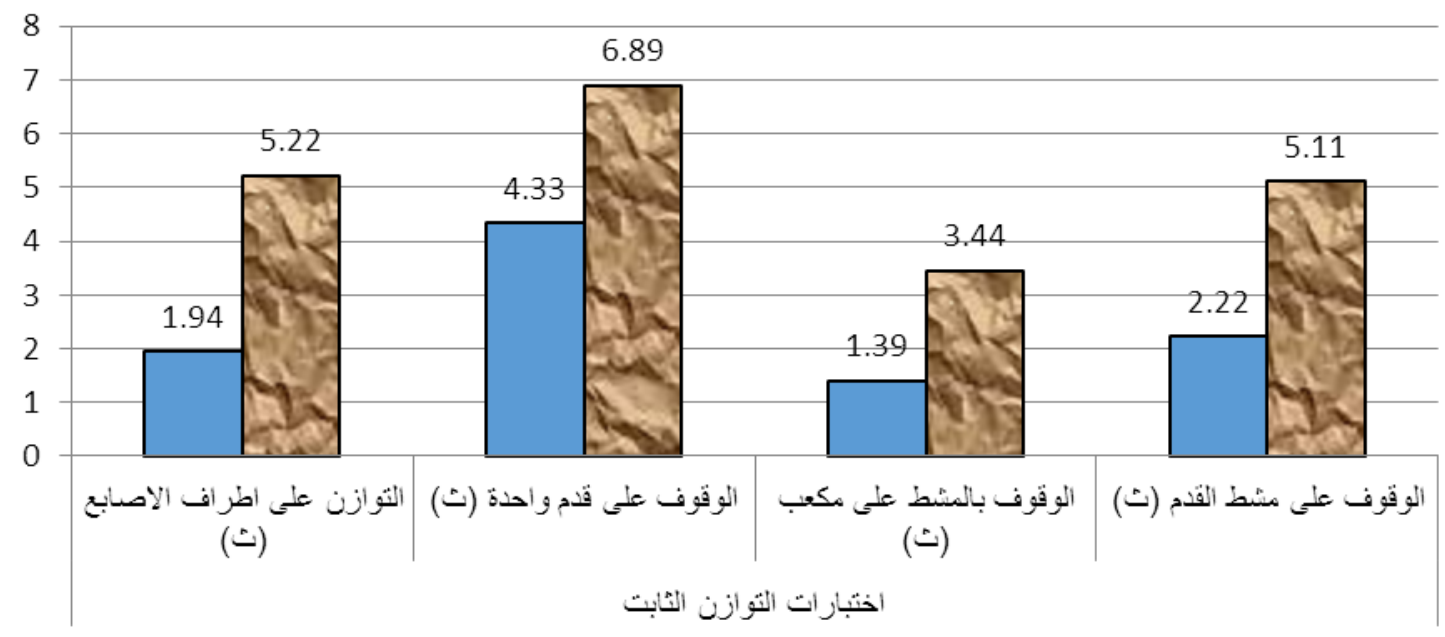

شكل ( r) المتوسط الحسابى بين القياس القبلى والبعدى فى التوازن الثابت لناشئات الجمباز الايقاعي

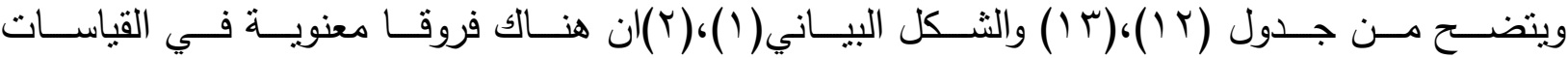
الخاصــة بـالتوازن الحركـي والثابــ ، قبـل وبعـد اجـراء التجربـة وجـاءات نسـبة التحسـن لصــالح

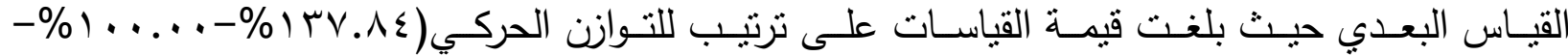

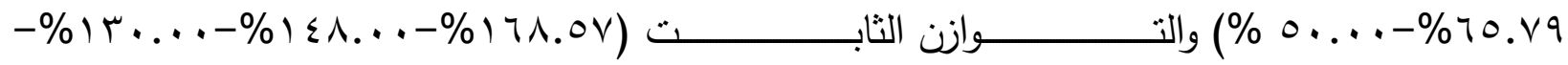




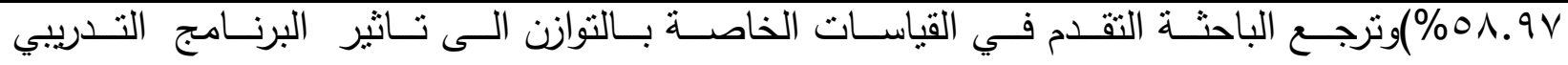

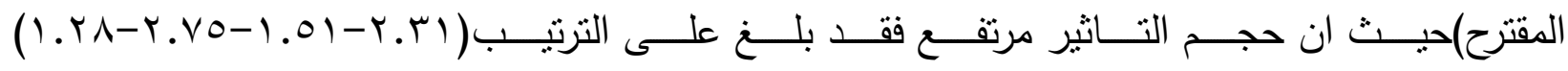

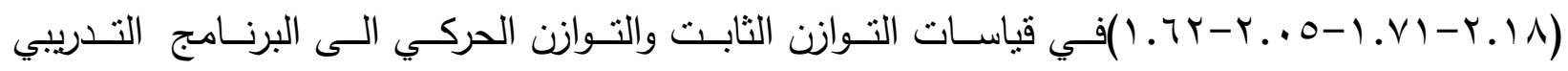
المقترح الـذى اشـتمل على تـدريبات خاصـة بـالتوازن الثابـت والحركي باسـتخدام النصـف كـرة الهوائيـة

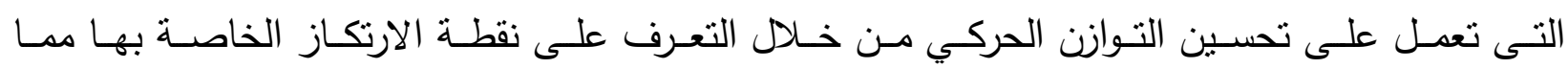

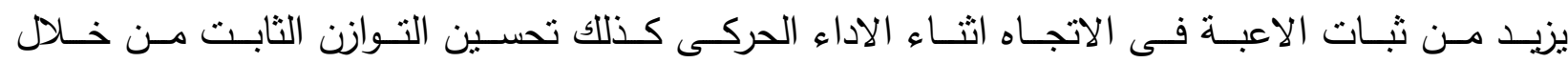

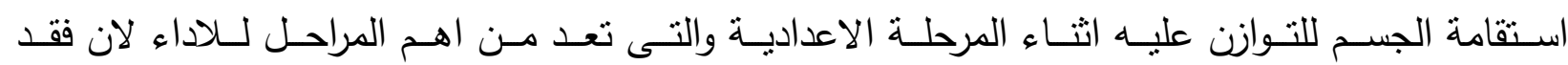

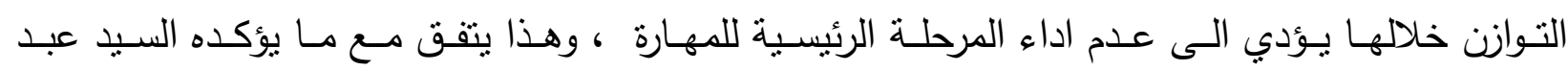

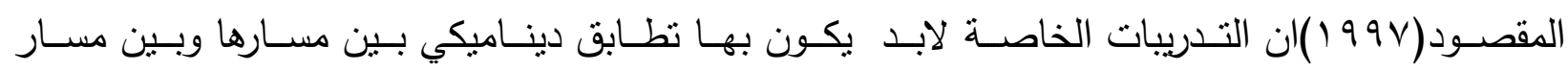
التكنيـك ،وتـؤدي ايضــا الـى تطـوير الصـفات الدينامكيـة للتكنيـلك ،مـع ضــرورة محاكـاة المسـار الزمنـي •وتم تطبيـق التـدريبات بطريقـة متدرجـة اعتمـادا على الاسـس الخاصـة بمراحل الـتعلم المهـاري وكذلك وفق التركيب الزمني المكاني (التركيب الديناميكي الزمني)(الايقاع)(؟: 0ـ؛

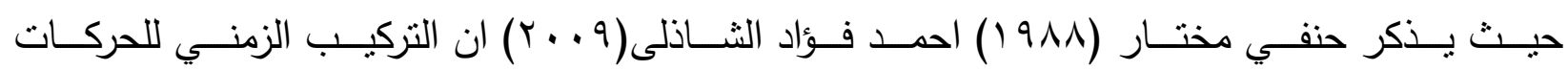

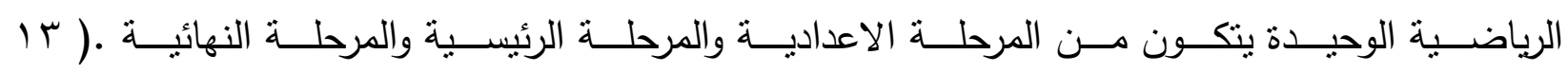
$(09: \varepsilon)(1) \leqslant \varepsilon:$

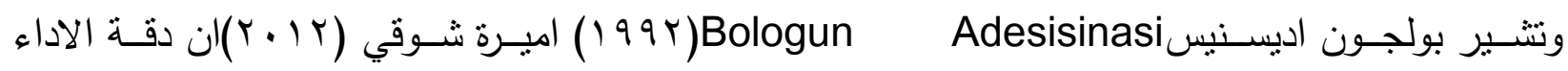

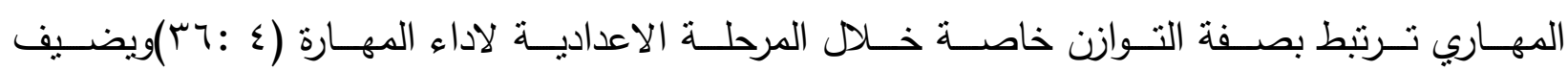

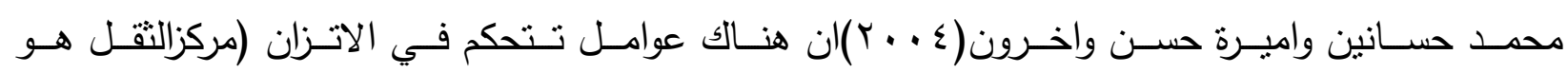

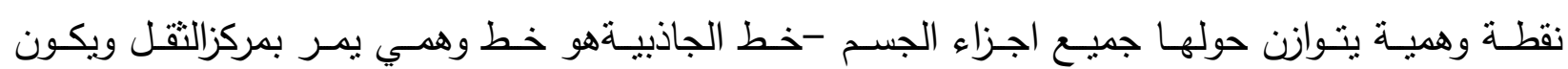
عمـودي على الارض - قاعـدة الارتكـاز هـى عبـارة عـن مسـاحة السـطح الـذي يرتكـز عليـة الجسـم) ،فـاذا كـان المطلـوب هـو التـوازن الثابــت فيجـب ان يقـع خـط الجاذبيـة داخـل قاعـدة الاتـزان واذا كـان الهـدف التـوازن الحركي فيلـزم تحريـك خـط الجاذبيـة الـى خـارج قاعـدة الاتـزان وذلك حتى تـتم الحركـة

$$
(r Y: \vee)(\vee T: \leq T) \text {. }
$$

وهـذا يتفـق مـع جاسـتر جمبسـكاي(999 (19)علـى ان التـوازن مـن المكونـات الاساسـية الهامـة لتطـوير مسـتوى الاداء المهـاري للاعبـة الجمبـاز الايقـاعي فهى تحتــاج الاحتفــاظ بثابــت الجسـم دون سـقوط او

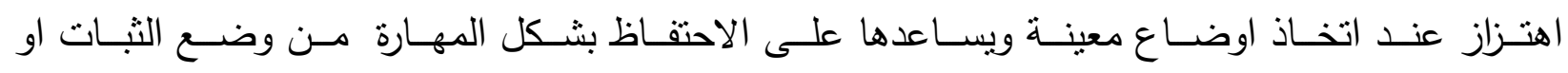

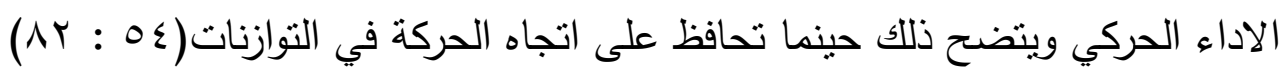

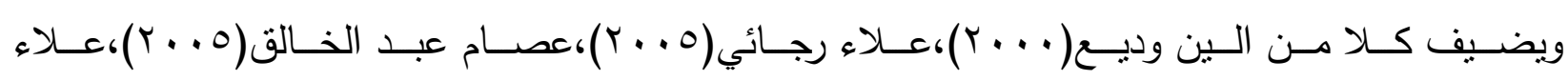

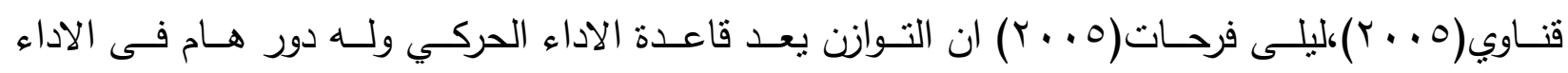




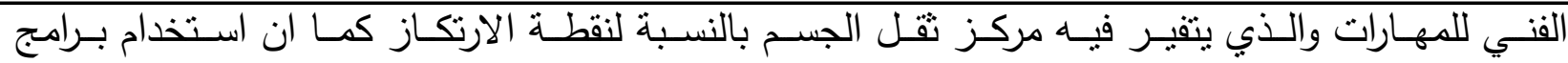

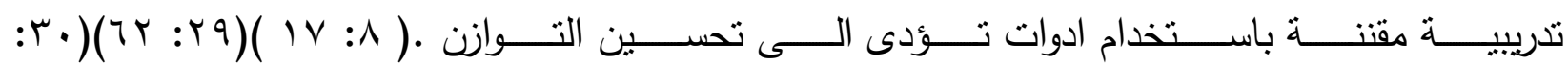

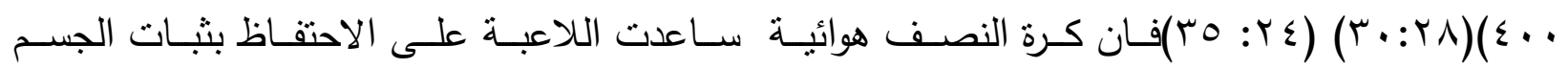

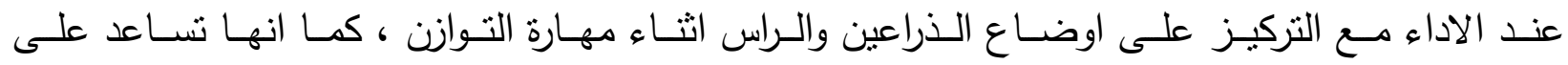

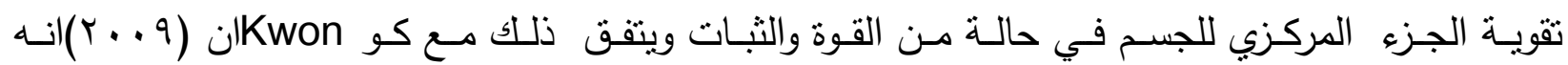
لتحقــق التـوازن يجـب الحفـاظ علـى الجـزء المركزي مـن الجسـم فـي حالـة قـوة وثبـات حيـث يكـون

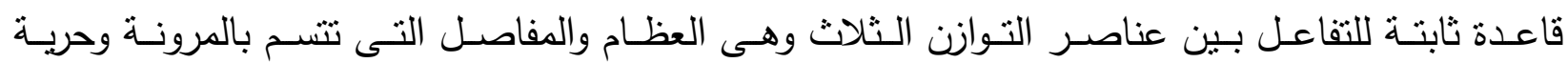
الحركة التي تتسم بالقوة والاطالة وعنصر التحكم في الحركة بشكل جيد . (10: فلابــــ على اللاعبـة الاحتفـاظ بتـوازن جسـمها اطـول فتـرة ممكـة لإظهـار جمـال شـكل الاداء والمهـارة

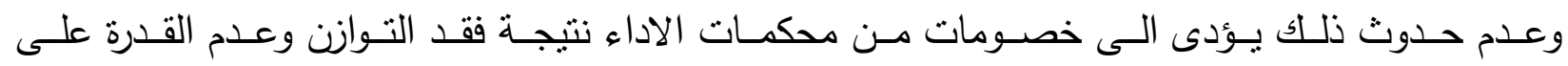

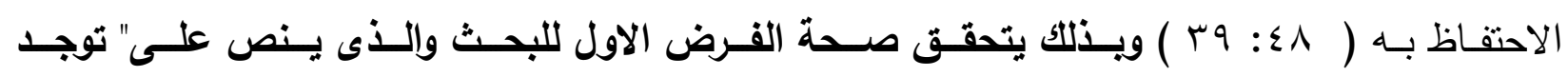
فـروض دالـة احصـائيا بـين القياسـين القبلى والبعـى لصـالح القبـاس البعـدى فى اختبـارات التـوازن

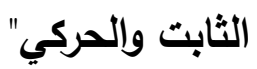
جدول ( ؛ (1) المتوسط الحسابى والإنحراف المعيارى ونسبة التحسن وحجم التأثير وقيمة " ت " المحسوية بين القياس القبلى والبعدى فى تحمل

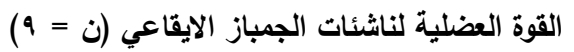

\begin{tabular}{|c|c|c|c|c|c|c|c|c|c|c|c|}
\hline \multirow[t]{2}{*}{ الدلالة } & \multirow{2}{*}{ قلتيمة } & \multirow{2}{*}{ التحسبة } & \multirow{2}{*}{ قيمة } & \multicolumn{2}{|c|}{ القرق بين } & \multicolumn{2}{|c|}{ القياس البعدى } & \multicolumn{2}{|c|}{ القياس القبلى } & \multirow[t]{2}{*}{ القياسات } & \multirow[t]{2}{*}{ b } \\
\hline & & & & $\varepsilon \pm$ & س־` س & $\varepsilon^{ \pm}$ & س- س & $\varepsilon^{ \pm}$ & س- س & & \\
\hline مرتفع & $1 . r \varepsilon$ & $\varepsilon \varepsilon . V \varepsilon$ & $* * \wedge .1 T$ & $1 . r q$ & r.v^ & T.AT & IT.rT & t.IT & $\wedge . \varepsilon \varepsilon$ & وضنع القرفــاء القفـز العدـودي مـن & 1 \\
\hline مرتفع & 1.19 & $r \varepsilon .10$ & $* * 1, \ldots 7$ & .94 & r.11 & r.rq & M.TY & l. & 9.11 & الجلوس من الرقود (عدد) & r \\
\hline مرتفع & .97 & $r \varepsilon . r$. & $* * \wedge . r Y$ & 1.00 & Y. . & t.rt & $1 \leq . \vee \wedge$ & 1. & 11.19 & رفــع الجــــع مــن الانبطــاح & r \\
\hline مرتفع & $1 . \leqslant 9$ & $\varepsilon \wedge . .0$ & $* * \wedge . \leqslant 9$ & $1 . \leqslant 0$ & ะ.11 & T.V $\varepsilon$ & IT.TV & $1.9 \varepsilon$ & 1.07 & 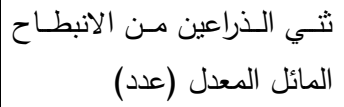 & $\varepsilon$ \\
\hline
\end{tabular}

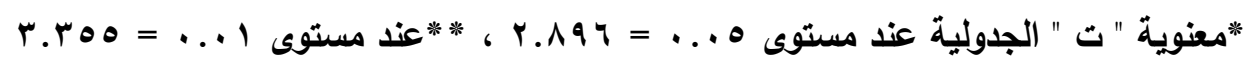

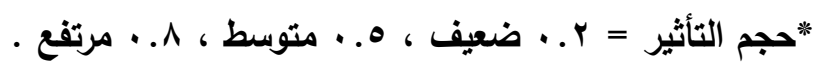

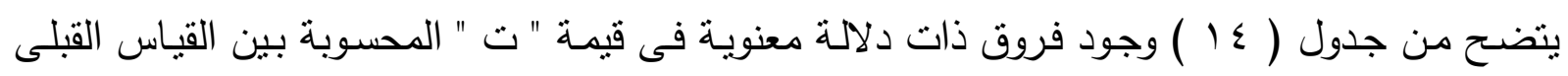

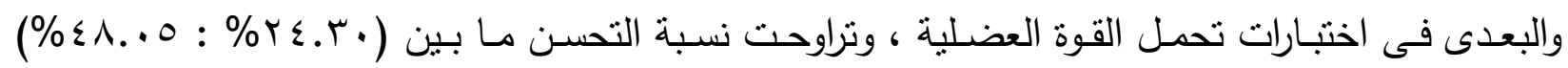

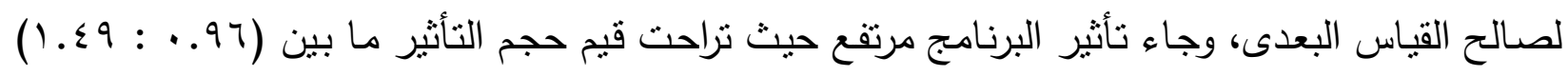
وهى قيم مرتفعة أكبر ^. . ممـا يدل على التأثير الايجـابى لتطوير تدربيات التوازن الثابت على القدرات البدنية لناشئات الجمباز الايقاعي. 
القياس البعدى ه القياس القبلى ه

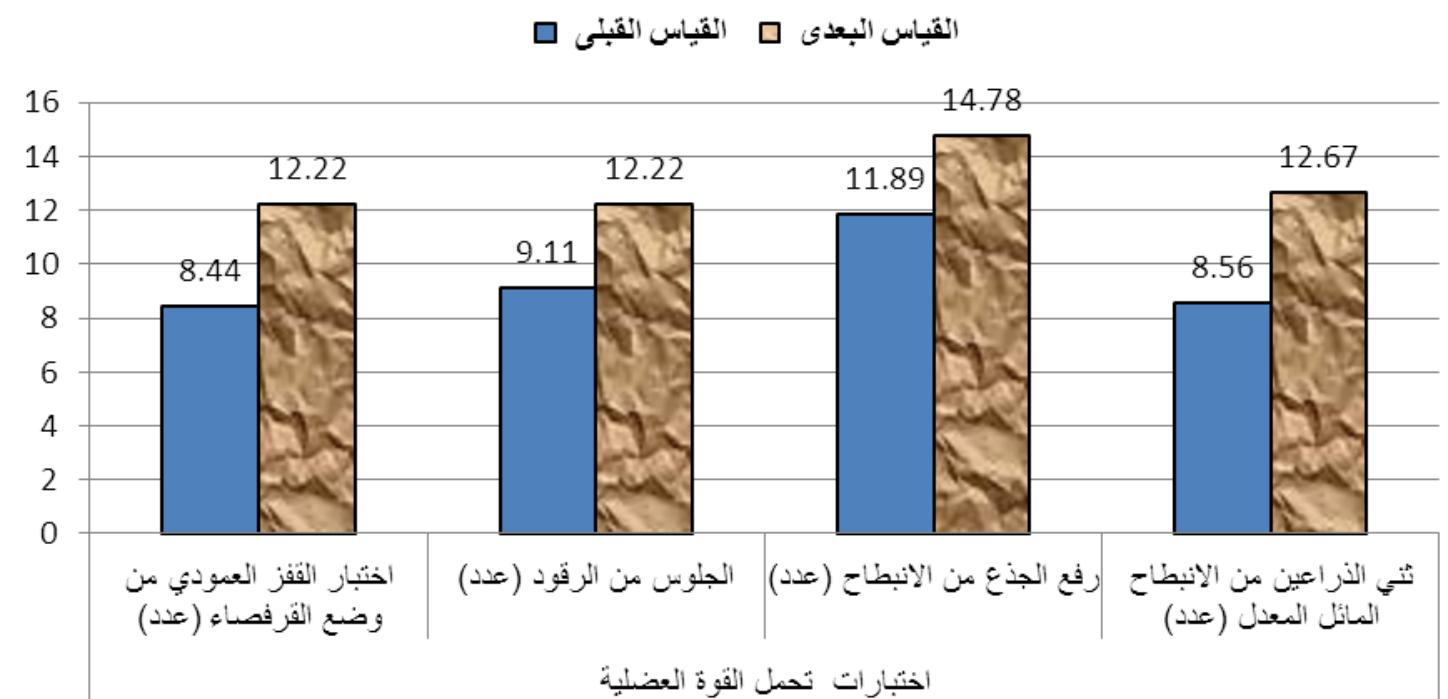

المتوسط الحسابى بين القياس القبلى والبعدى فى تحمل القوة العضلية لناشئات الجمباز الايقاعي كـللك يتضـح مـن جـول (ع () وشـكل(ب) ان هنـاك فروقـا معنويـة في القياسـات الخاصـة بتحمـل القوة

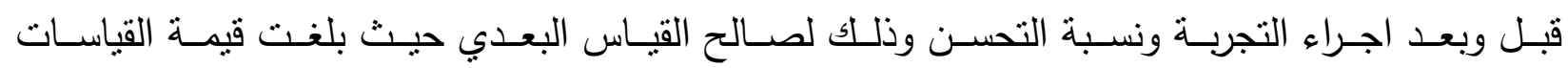

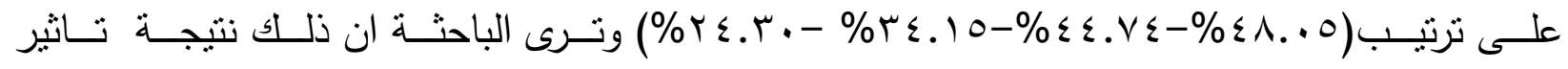
برنــامج التـدريبي المقتـرح والـذي حيــث ان حجـم تـاثيره المرتفـع فـي القياسـات الخاصــة بتحمـل القـوة

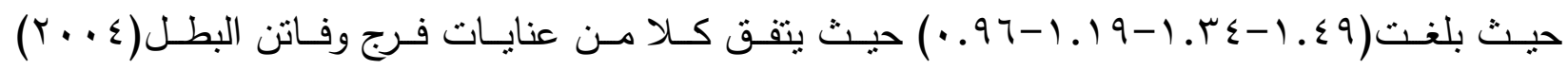
وياسـمين البحسار وسـوزان طنطـاوي(ع . . r) على ان لاعبـة الجمبـاز الايقـاعي تحتـاج الـى قدر كبيـر مـن تحمـل فـى كـل اجـزاء الجسـم حتى تســطيع ان تـؤدى المهــارات المختلفـة اذ لاتسـتطيع الاعبـة اتقـان المهـارات الاساســية فـي حالــة افتقارهــا للصـفات البدنيــة حيـث ان المهـارات المختلفـة لايــتم

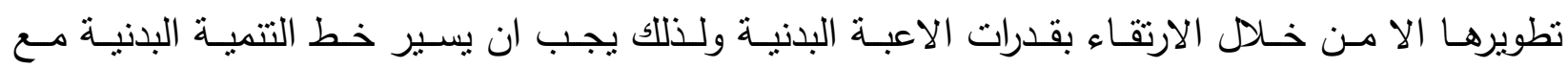

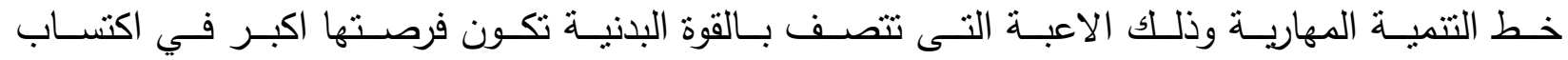

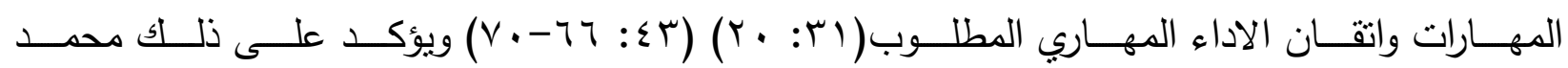

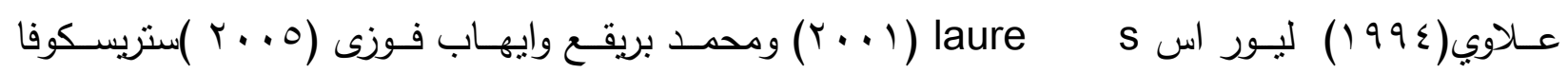

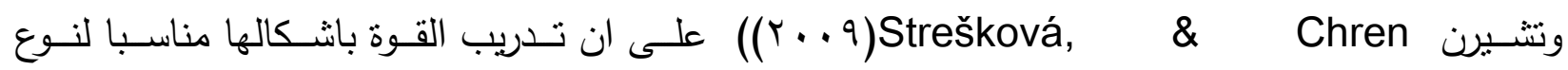
الانقباضـات العضـلية السـائدة والعاملـة فـي الاداء المهـاري للمهـارة المختـارة ولـذلك يجـب على المدربـة

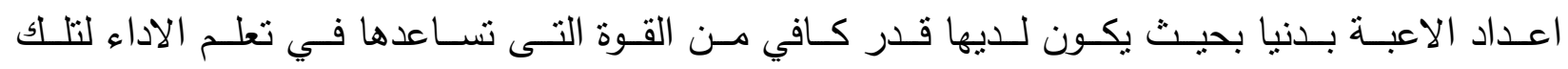

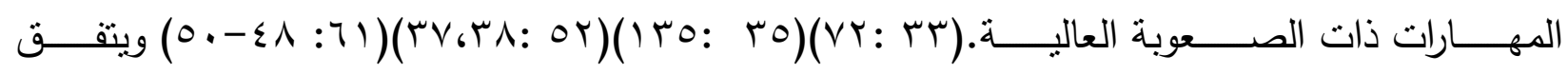

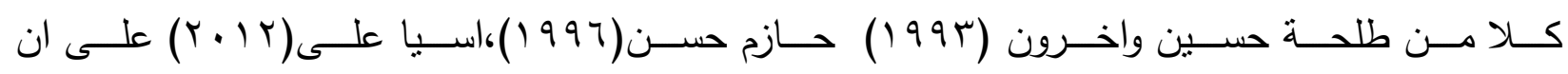
التـدريبات المشـابهة لـنفس المسـار الحركي للمهـارة هـي اقصـى درجـات التخصـص فـي تتميـة الاداء المهـاري كمــا ونوعـا وتوقيتـا وفقـا للاسـتخدامات اللحظيـة للعضــلات او المجموعـة العضـلية داخـل

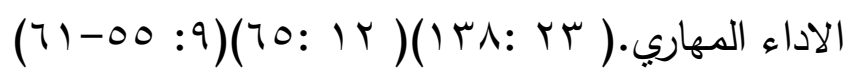

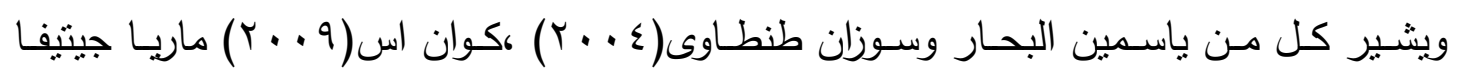


Maria Gateva

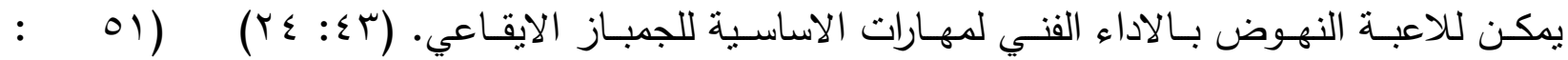

$$
(\{\wedge-\varepsilon 0: 00)(7)
$$

جدول ( 10) المتوسط الحسابى والإنحراف المعيارى ونسبة التحسن وحجم التأثير وقيمة " ت " المحسوية بين القياس القبلى والبعدى فى المرونة

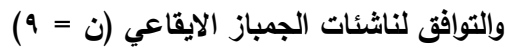

\begin{tabular}{|c|c|c|c|c|c|c|c|c|c|c|c|}
\hline \multirow[t]{2}{*}{ الدلالة } & \multirow{2}{*}{ قيمة } & \multirow{2}{*}{ التحسبة } & \multirow{2}{*}{ قاتمة } & \multicolumn{2}{|c|}{ القرق بين } & \multicolumn{2}{|c|}{ القياس البعدى } & \multicolumn{2}{|c|}{ القياس القبلى } & \multirow[t]{2}{*}{ القياسات } & \\
\hline & & & & $\varepsilon^{ \pm}$ & س- - س & $\varepsilon \pm$ & س- - س & $\varepsilon \pm$ & س- & & \\
\hline مرتفع & 1.70 & $7 . . \wedge V$ & $* * 10.04$ & .7 & r.11 & $1 . V r$ & r... & 1.9. & 0.11 & اختبـار ثتى الجـذع جانبـا & \multirow{4}{*}{ المتبارات } \\
\hline مرتفع & r.11 & $09.0 \mathrm{~V}$ & $* * 10.01$ & .7. & r.11 & $1 . \leqslant 0$ & r.11 & $1 . r 9$ & $0 . r Y$ & اختبـــار الفجــوة الجانبيــة & \\
\hline مرتفع & 1.01 & $0 \leqslant .00$ & $* * 11.00$ & $\cdot . \wedge \vee$ & אז.T & $1 . V Y$ & r.VA & $r .10$ & 7.11 & اختبار تدوير العصا (سم) & \\
\hline مرتفع & 1.19 & $\varepsilon V . T V$ & **V.ro & I.rT & r... & r... & rז." & $r .00$ & איד & 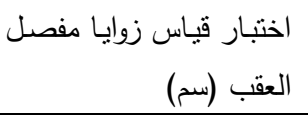 & \\
\hline مرتفع & $1 . \leqslant 1$ & $9 \leq . \leq \varepsilon$ & $* * \mid \vee \ldots$ & זr.. & 1.19 & $1 . \mathrm{TV}$ & r.人9 & $1.1 \mathrm{r}$ & r... & التوافق الكلي (اختبـار نط & \multirow[b]{2}{*}{ التنبارات } \\
\hline مرتفع & .94 & Y0.74 & $* * 1 \leq .0$. &.$T V$ & T.rt & $1.9 \leqslant$ & q.r & T. $\leqslant 7$ & $1 Y .07$ & 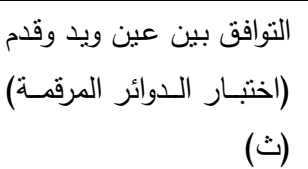 & \\
\hline
\end{tabular}

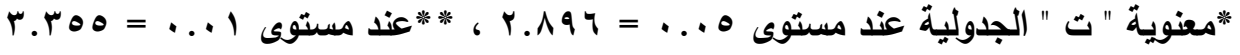

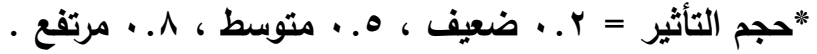

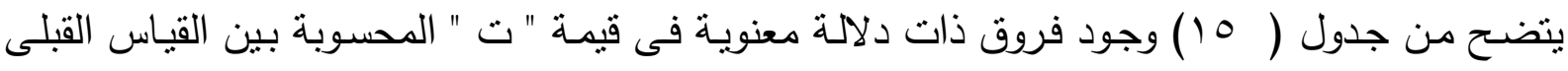

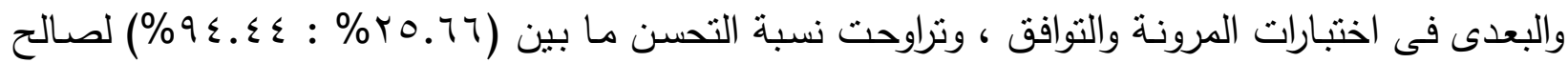

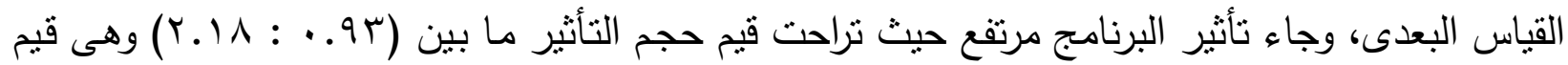
مرتفعة أكبر ^.. مما يدل على التأثبر الايجابى لتطوير تدريبات التوازن الثابت على القدرات البدنية لناشئات

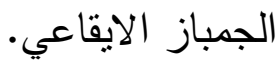


القياس البعدى هـ القياس القبلى ه

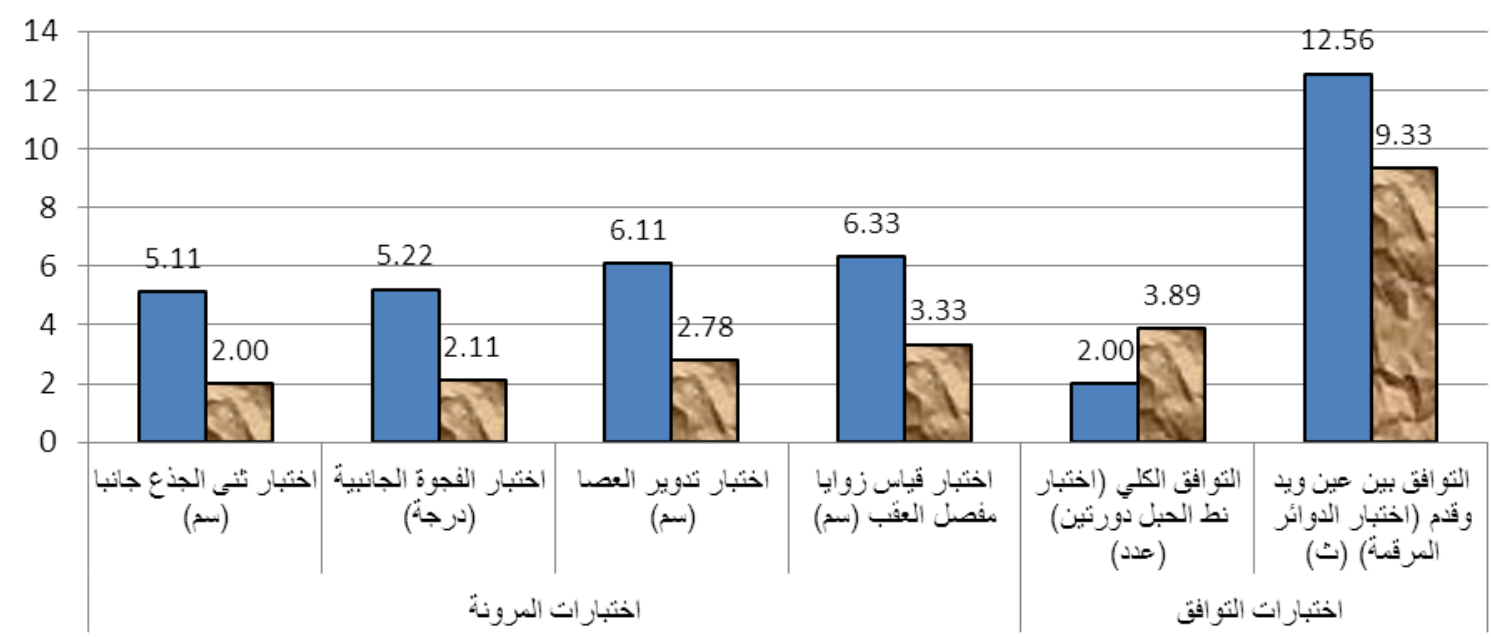

شكل ( ؛ ) المتوسط الحسابى بين القياس القبلى والبعدى فى المرونة والتوافق لناشئات الجمباز الايقاعي

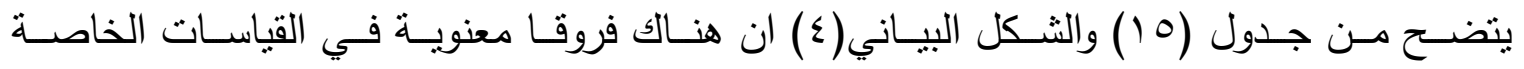

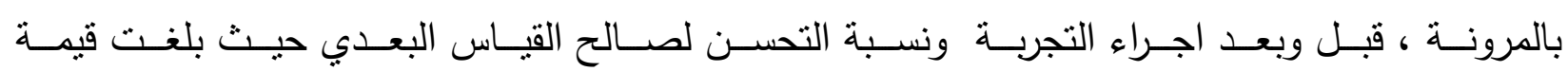

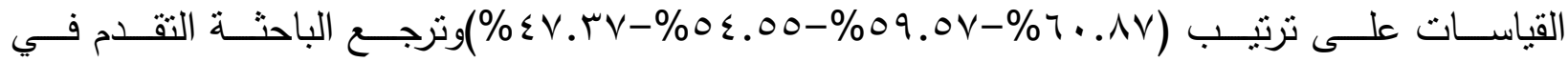

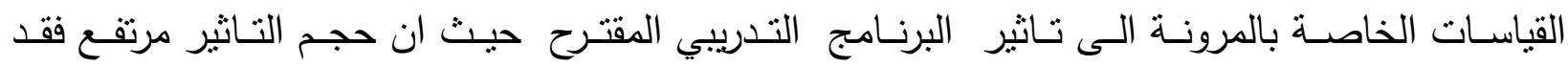

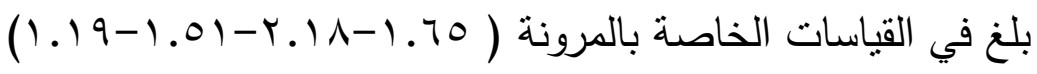

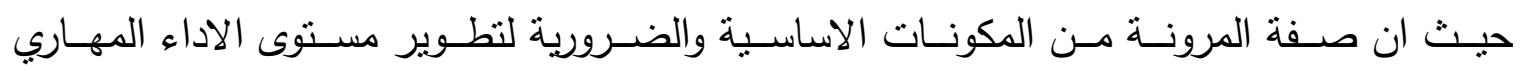

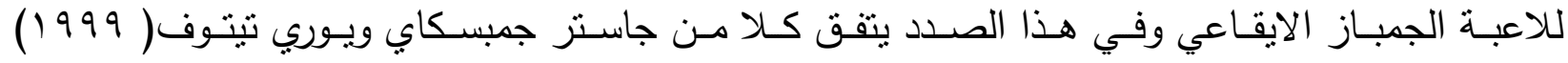

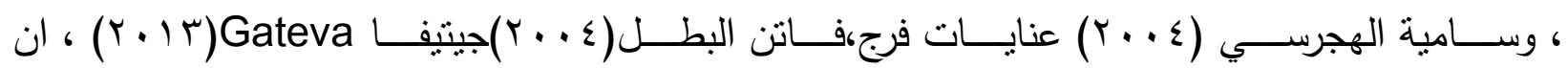

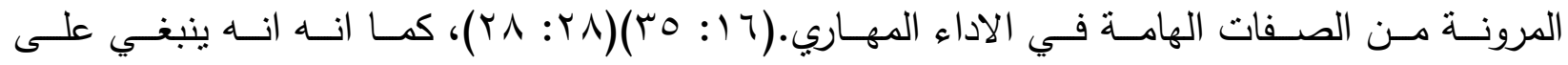

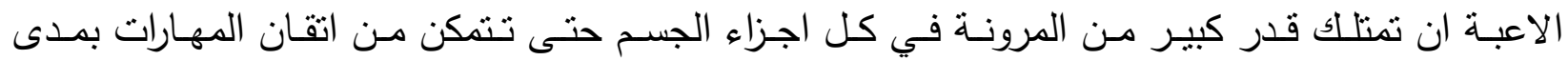

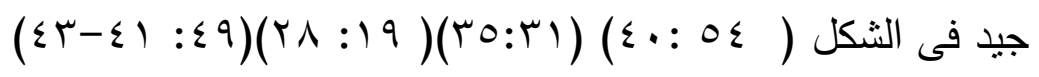

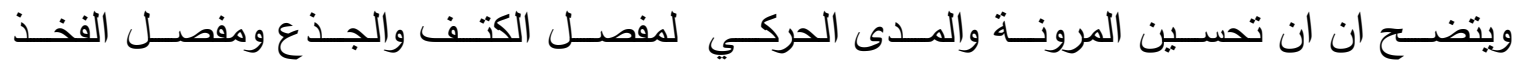

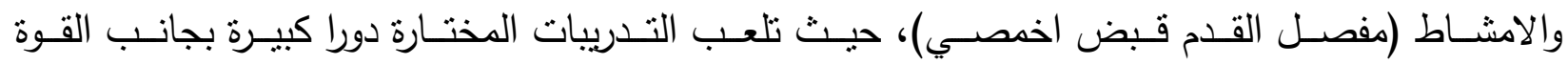

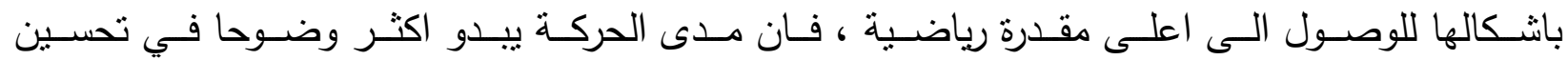

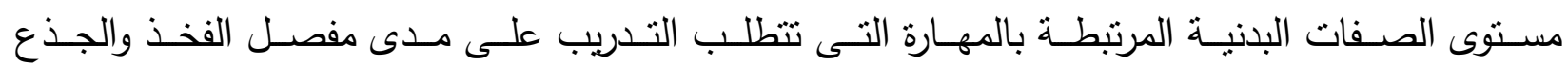

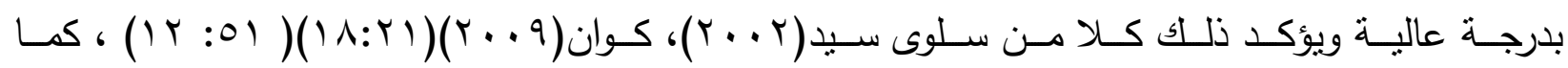

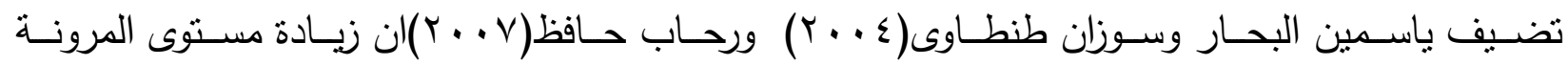
يـؤدى الى اتسـاع مدى الحركـة في المفاصـل الى مسـتوى عـالي وذلك مـن اهـم المنطلبـات في الاداء

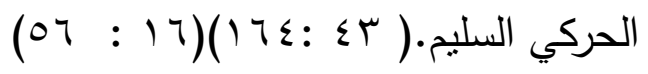




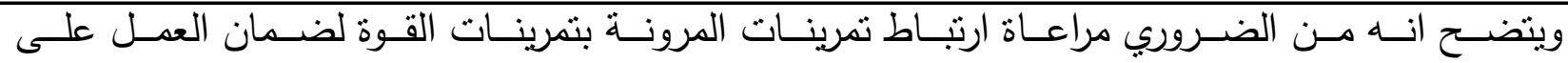
القيمـة المتزنــة للجهـاز العصـبي كوتجنـب تتميـة جانـب واحـد فقـط حيــ ان مرونـة وقـوة العضــلات العاملة تطور الاداء المهاري ( سع : . T) (09: 00-rr) والقدرات البدنيـة مرتبطـة ارتبـاط مباشـر بـالتوافق وتـؤثز فيـهـ وتتـاثر بـهـ وهـو مـن اهـم الصـفات التـي يجـب توافرهـا فـى لاعبـة الجمبـاز الايقـاعي والتـى تـرتبط بالجوانـب البدنبـة والعقليـة والايقاعيـة فعـن طريقـه تسـتطيع الاعبـة الـتحكم فـي الاداء الحركي بثـكل متتاسـق وهـو عنصـر مركـب يتطلـب النوازن والمرونة والقوة.

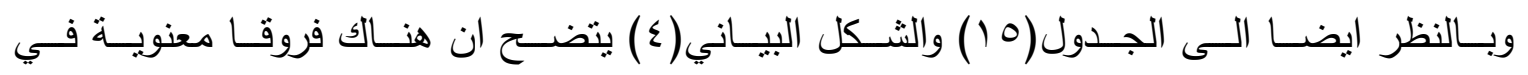
القياسـات الخاصــة بـالتوافق قبـل وبعـد التجربـة ونسـبة التحسـن وذلـك لصـالح القيـاس البعـدي والتـى

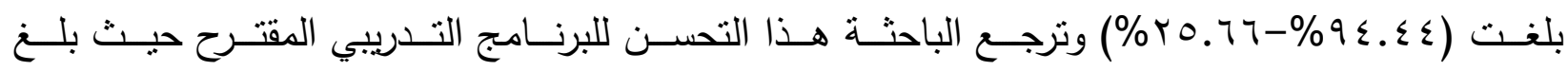

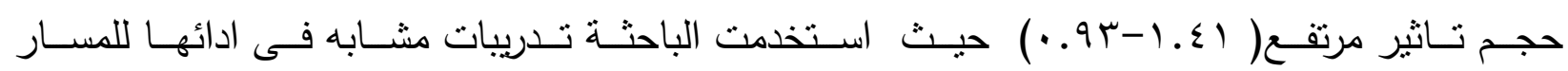

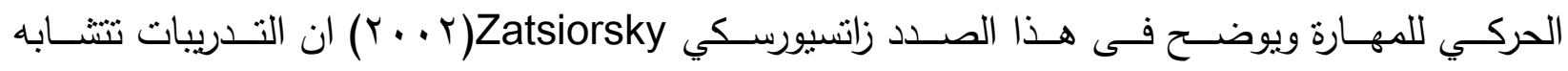
فـي تكوينهـا مـن حيـث تركيـب الاداء المهـاري مـن قـوة وسـرعة والمسـار الزمنـي للقـوة وكـللك اتجــاه العمـل العضـلي منهـا مـع تلكـ الحركـات المـؤداه ،ولـذلك فهـي وسـيلة مباشـرة للاعـداد الرئيسـي للمسـتوى الرياضـي لتطـوير الحالـة التدربيــة للاعبـة بحيـث تكـون مناسـبة مـع الاداء المهـاري مـن حيـث التوافـق

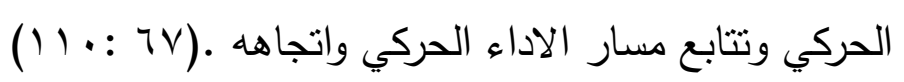

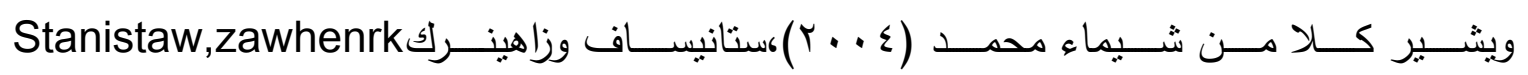

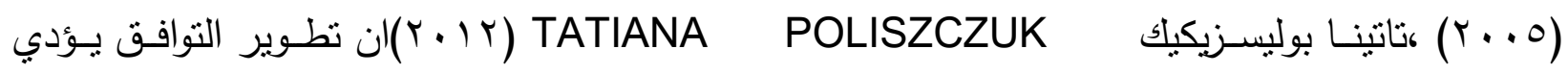
الـى تحقـق توافـق كلـي للجسـم ممـا يمكن الاعبـة مـن القدرة على الـربط الحركي بدقـة وتحكم لمراحل

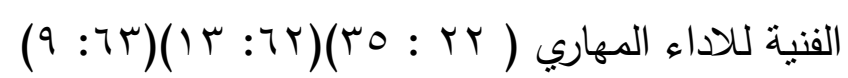

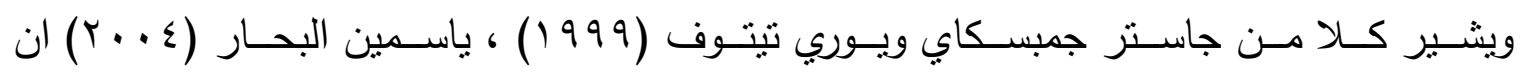
التوافت يمكن ان يكـون كليـا او جزئيـا فـان توافق الاطـراف هـو الـذي يظهر توافـق القدمين او الـرجلين

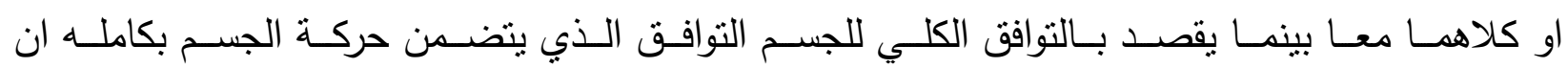

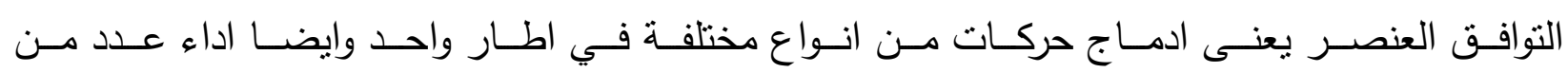

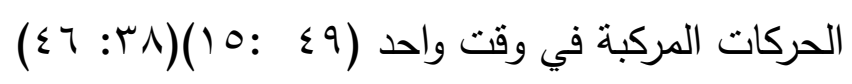

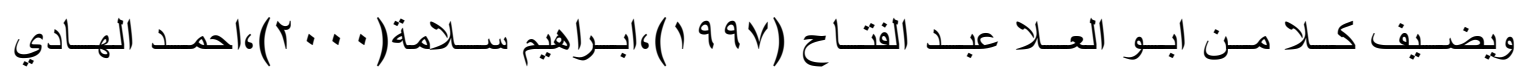

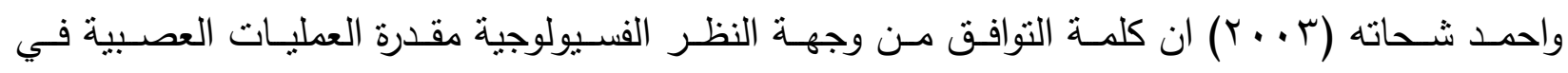

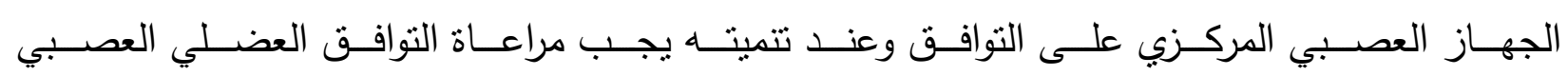
والاحسـاس بالحركـة مـن خــله تحليـل الاداء الحركـي ومسـتويات القـدرات البدنيـة الاخـرى فالقـدرات التوافقيـة لاتظهـر بشـكل منفـرد ولكـن تـرتبط مـع المرونـة والقـوة والتـوازن ،فهـو مقدرة حركيـة تتطلـب 


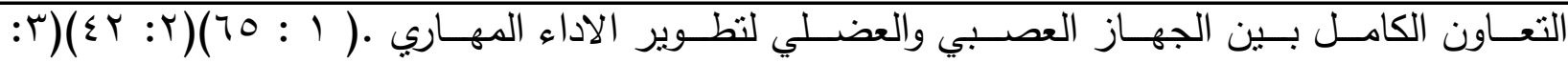

وترجـع الباحثـة نسـبة التحسـن فـى اختبـارات القـدرات البدنيـة نتيجـة لتـاثير البرنـامج المقتـرح

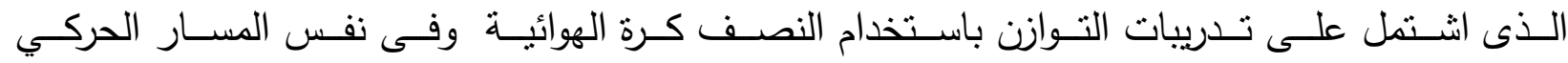
للمهـارة فيـد البحـث حيـث انهـا تسـاعد الاعبـة على الـتحكم في الفـراغ والعنصـر انتـاء التوازنـات (بآ)

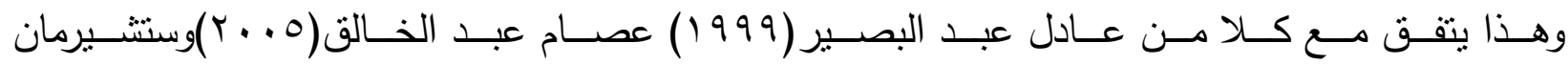
Schurman

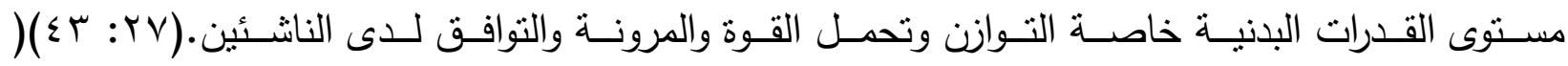

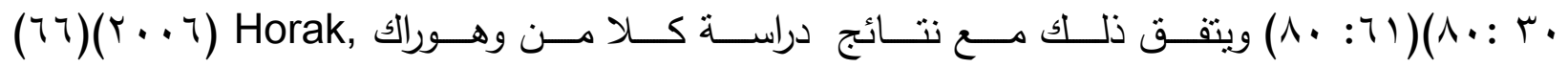

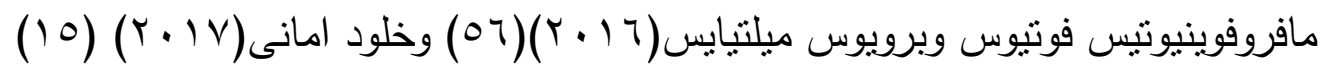

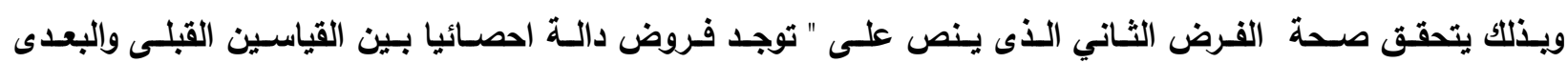

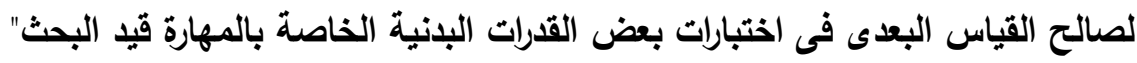

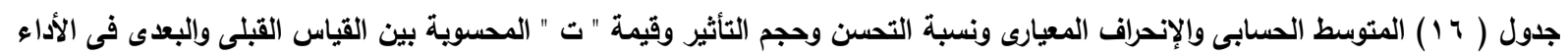

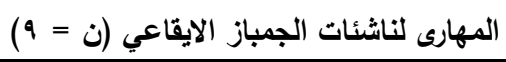

\begin{tabular}{|c|c|c|c|c|c|c|c|c|c|c|c|}
\hline \multirow[t]{2}{*}{ الدلالة } & \multirow{2}{*}{ قيمة } & \multirow{2}{*}{$\begin{array}{c}\text { التحسنة } \\
\text { \% }\end{array}$} & \multirow{2}{*}{ |قاتمة } & \multicolumn{2}{|c|}{ الفرق بين } & \multicolumn{2}{|c|}{ القياس البعدى } & \multicolumn{2}{|c|}{ القياس القبلى } & \multirow[t]{2}{*}{ القياسات } & \multirow[t]{2}{*}{ r } \\
\hline & & & & $\varepsilon^{ \pm}$ & س- & $\varepsilon^{ \pm}$ & س- & $\varepsilon^{ \pm}$ & س- س & & \\
\hline مرتفع & $r . .7$ & ITV.o. & $* * 10.11$ & $\cdot . \leqslant 7$ & T. $\varepsilon \varepsilon$ & . . & E.YY &.$v 1$ & $1 . \vee \wedge$ & الاررضل (درجة التمهيديـة (لحظــة تـرك & 1 \\
\hline مرتفع & r.Tr & $\vee 9.00$ & $* * 1$ Y.OV & .95 & $r . \wedge 9$ & $1 . .9$ & $\wedge . \vee \wedge$ & $1 . .0$ & $\varepsilon . \wedge 9$ & مدي) (درجة) المرحلة الرئيسة (لحظة أقصـي & r \\
\hline مرتفع & r.T & $1 \leq 0.17$ & $* * 10 \ldots$ & .0. & r.o. & $\because 9 V$ & E.YY & $\because$. & $1 . V T$ & 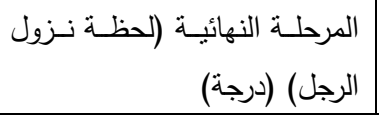 & $r$ \\
\hline مرتفع & $0 . r \leq$ & 1.0.r. & **19.ro & $1 . r v$ & N.یr & $1 . V r$ & IV.YY & 1.70 & N.r. & ذاء المهـاري للميزان الجـانبى بميل المستوى الافقى (درجة) & \\
\hline
\end{tabular}

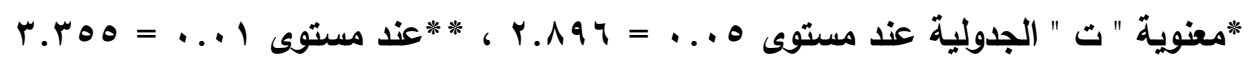

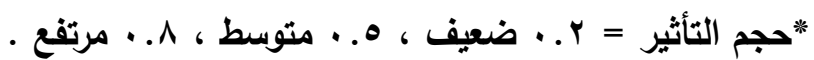

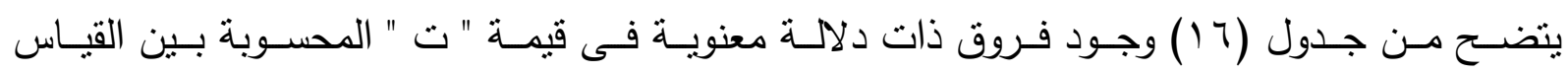

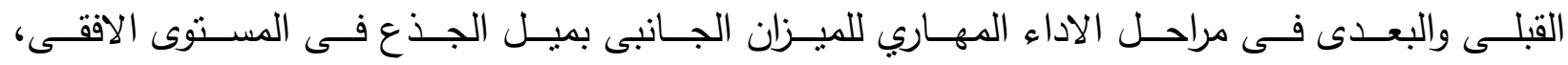

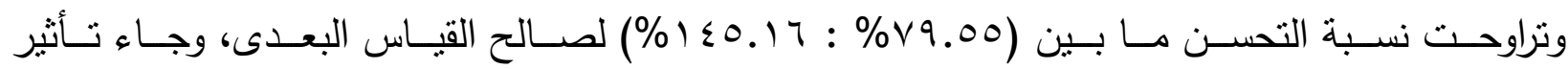

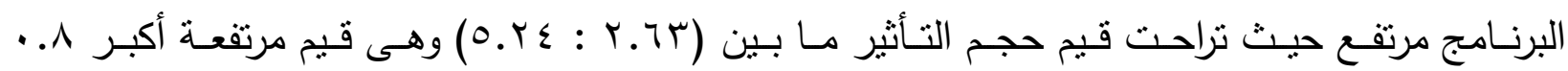
مدـا يـدل على التـأثنر الايجـابى لتطـوير تـدريبات التـوازن الثابـت على تحسـين مسـتوى الاداء المهـاري للميزان الجانبى بميل الجذع فى المستوى الافقى لناشئات الجمباز الايقاعي. 
الثقياس البعدى م التقيبس التقبنى ص

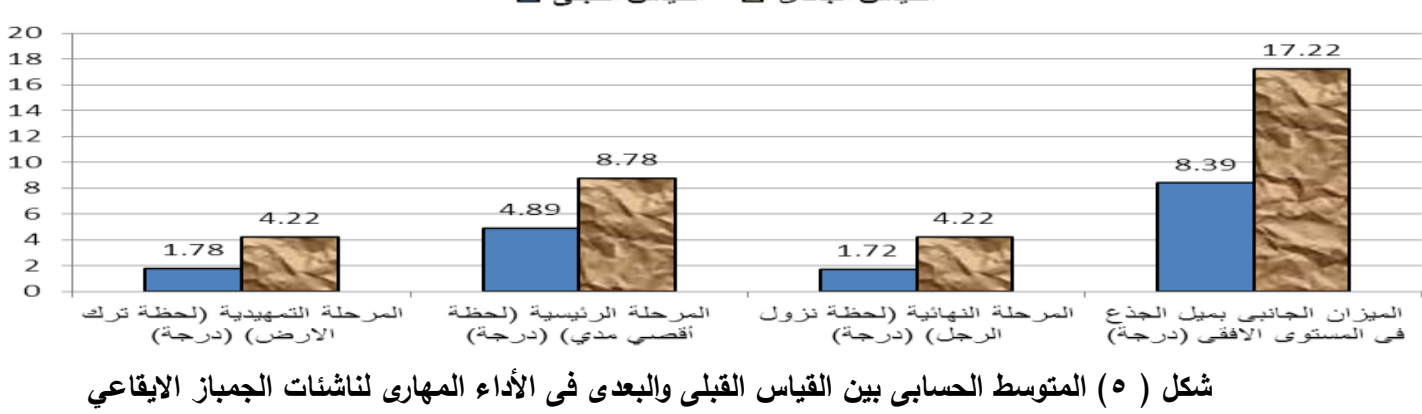

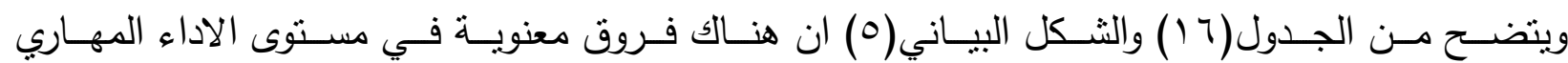

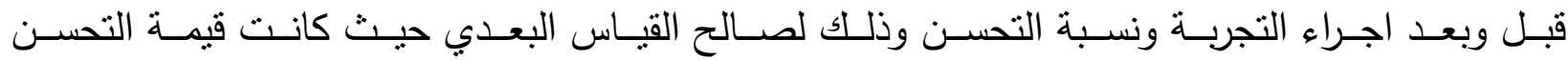

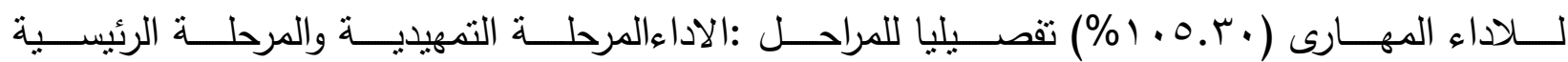

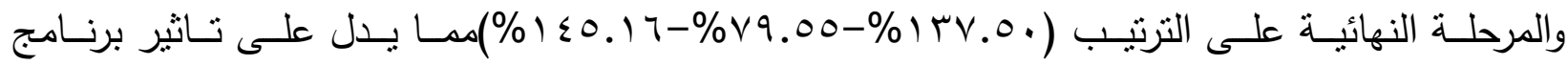

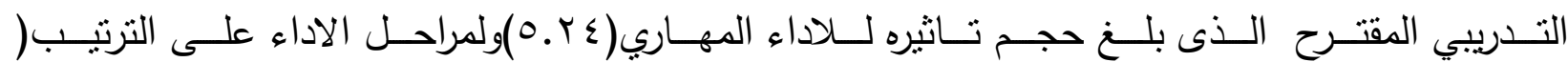

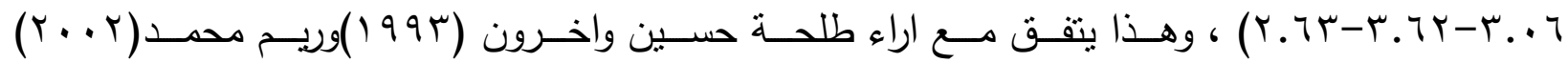
بـان استخدام تـدريبات التـوازن الششـابهة لـلاداء في التـدريب يـؤدي الـى تحسـين الاداء المهاري وتؤُثر

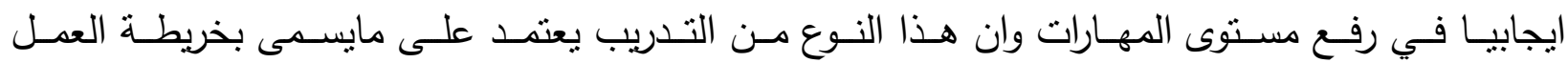

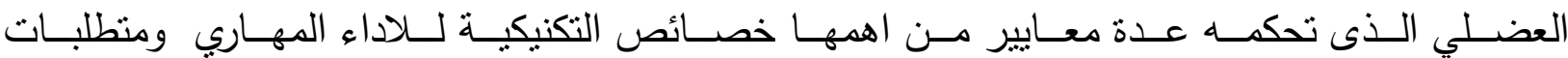

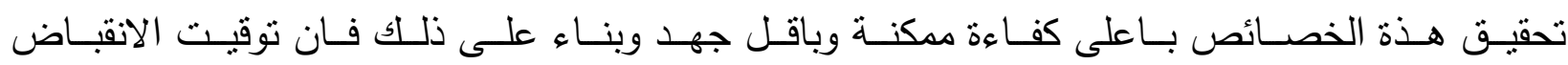

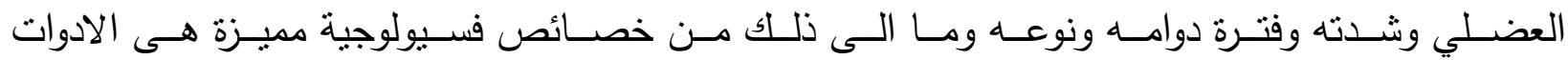

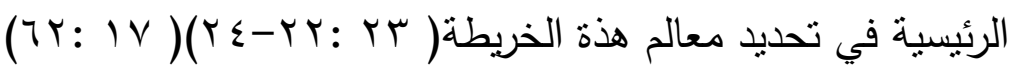

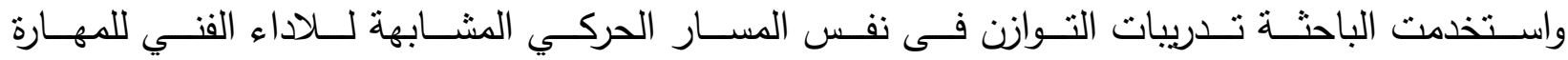

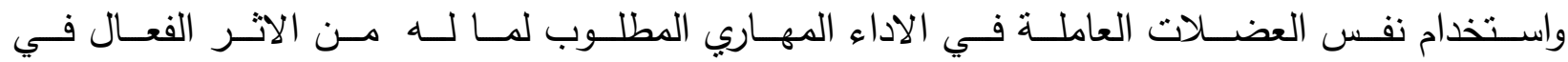

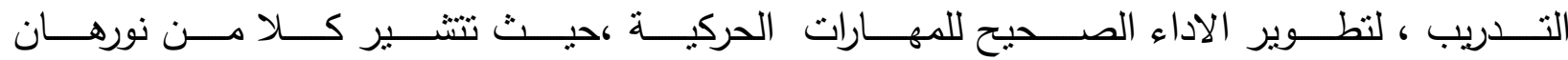

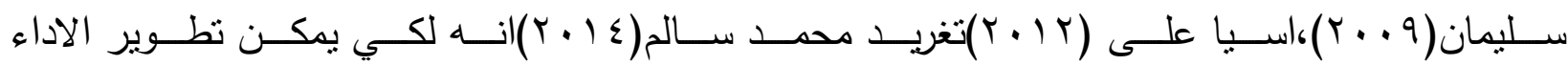

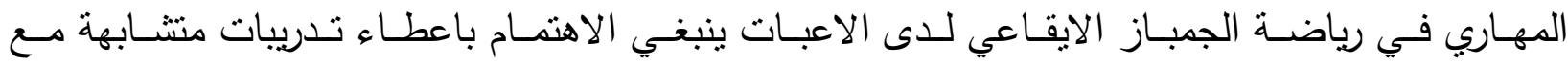

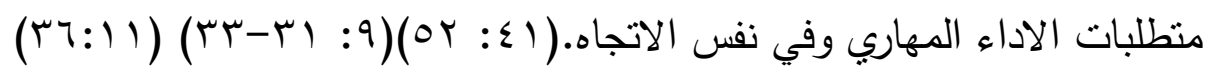

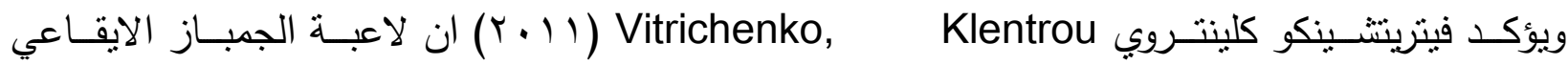

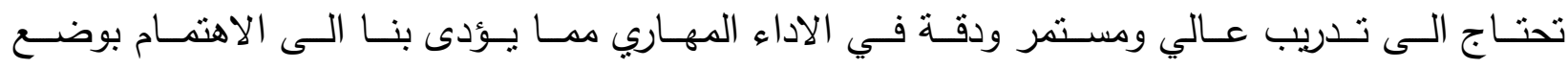

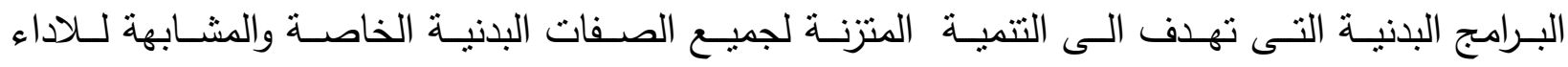

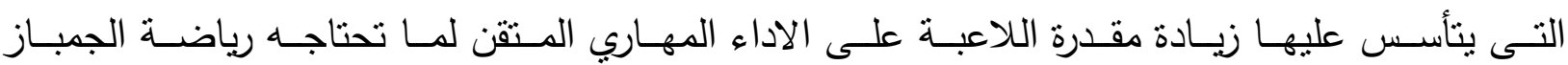

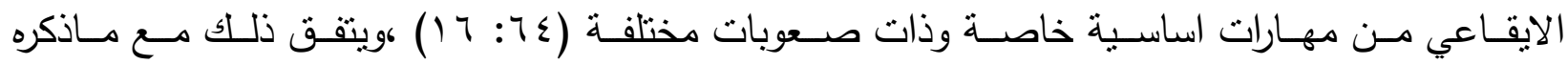

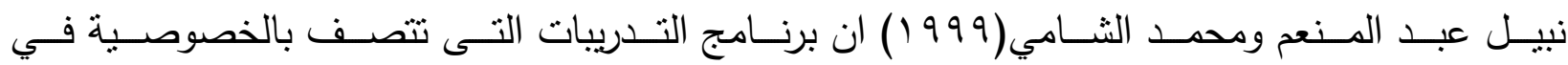


تحسـين القـدرات البدنيـة وفي عضــلات معينـة مـن الجسـم بحكم طبيعـة الاداء المهـاري حيــث تعدـل

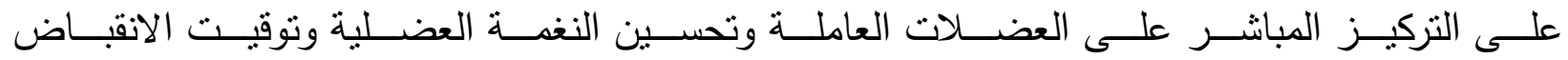
والانبسـاط اللازمـين لـلاداء ،فهذة التـدريبات تعدـل عـى تحسـين المســار العصـبي العضــلي لتطـوير

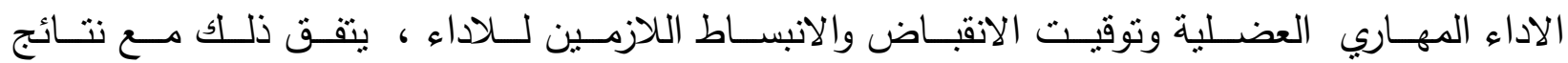

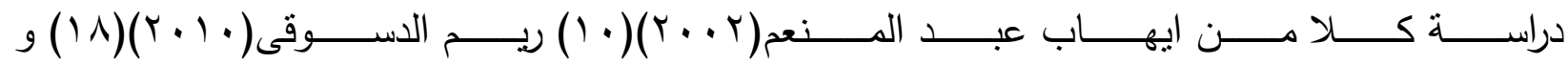

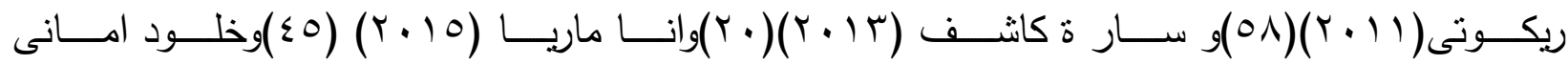

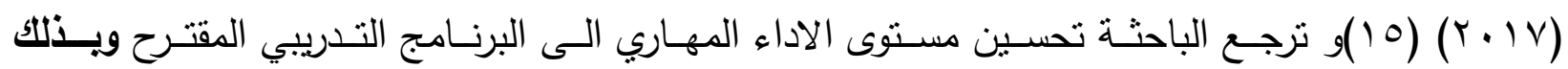
يتحقق صـحة الفرض الثالث الـذى يـص على " توجد فروض دالـة احصـائيا بـين القياسـين القبلى والبعـدى لصـالح القيـاس البعـى فـى مسـتوى الاداء المهـاري لمهـارة الميـزان الجـانبى بميـل الجـــع

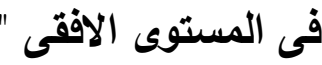
: الاستنتاجات : فـي ضـوء النتـائج التـي توصـلت اليهـا الباحثـة مـن خــله الدراســة امكـن التوصـل الــى الاسـتنتاجات الاتية:

ا- يسـهم البرنـامج التـدريبي المقترح باسـتخدام جهـاز النصـف كـرة الهوائيـة فـى تحسـين كـلا مـن

$$
\text { التوازن الثابت والحركي. }
$$

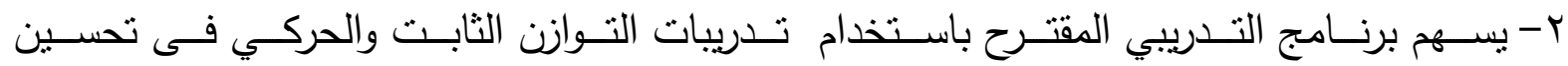

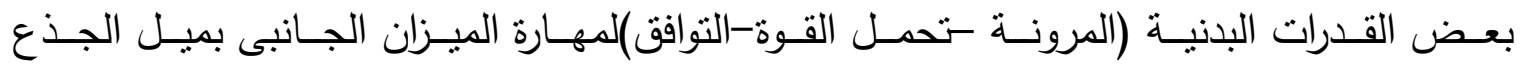
فى المستوى الافقى. ب- يـؤدى البرنـامج التـدريبي المقتـرح باسـتخدام تـدربيات التـوازن الثابــ والحركـي الــى ارتفــاع مستوى الاداء الفنى لمهارة الميزان الجانبى بميل الجذع فى المستوى الافقى.

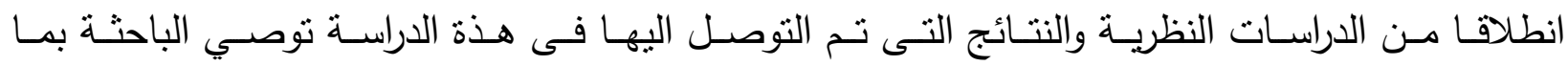

ا - تطبيق البرنامج المقترح لفاعليته وتاثيره الايجابي على مستوى الاداء المهاري، r- ضرورة اجراء القياسات الدورية للتوازن بنوعيه الثابت والحركي ومتابعة مستوى تطوره ب- ضـرورة توعيـة المـدربين باسـتخدام تـدريبات التـوازن بنوعيـه الثابـت والحركي لمـا لهـا مـن اثـر فــال فـي تطـوير مسـتوى الاداء المهـاري فـي الجمبـاز الايقـاعي بصـفة عامـة ومسـتوى اداء مهارة التوازنات بصفة خاصة. ع- ضـرورة اســتخدام الاجهـزة المســاعدة فـى رياضــة الجمبـاز الايقـاعي فهـى تعهـل علـى زيـادة فاعلية تعليم وتطوير الاداء المهاري . 
التــــرريب الرياضــــى والاســـس الفســــيولوجية ،دار الفكـــر العربي، القاهره

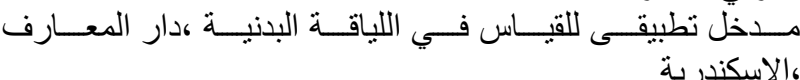
: تكنولوجيا الحركة في الجمباز ،مطبعة التوني،الاسكندرية

الموسـو عة الرياضـية فـى بيوميكانكيـا الاتـز ان ،منشـاة المعـارف

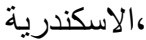

الاســس العلميــة لتــدريس التمرينـــات البدنيــة ذات السلاســلـ

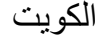

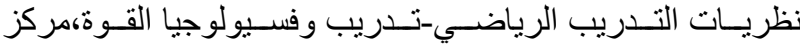
الكتاب للنشر ، القاهرة

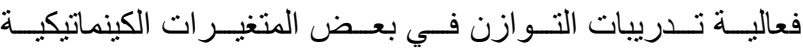

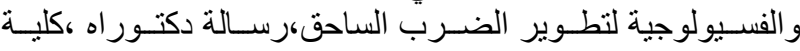
التربية الرياضية للبنات،جامعة الفئرية الاسكندرية.

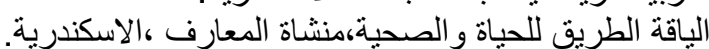

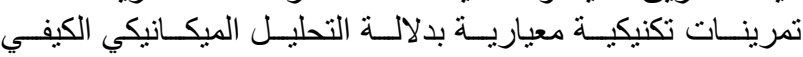

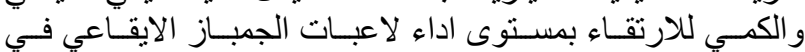

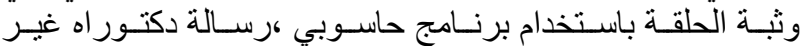
منشورة،كلية التربية الرياضية للبنات ،جامعة الاسكندرية.

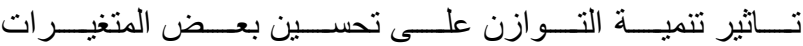

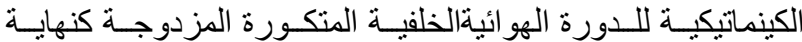

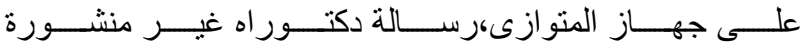
دببورسعيد،جامعة قنا السويس.

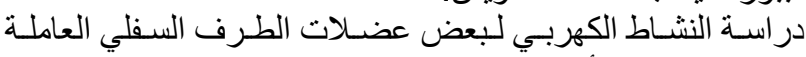

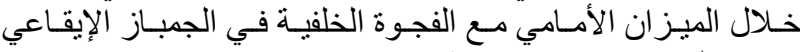

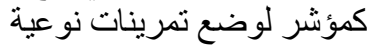

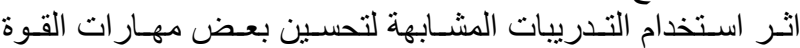

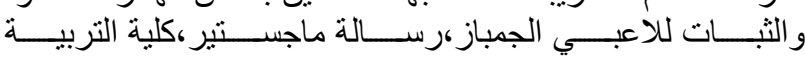

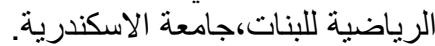

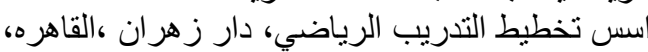

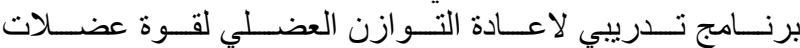

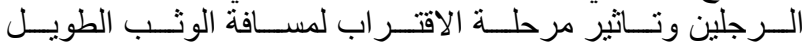
برسالة ماجستير ،جامعة الاسكندرية.

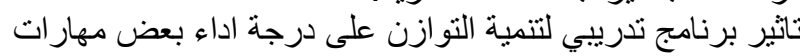
لناشئات الجمباز الايقاعي تلائي

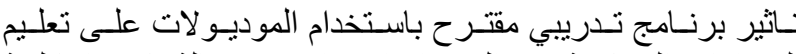

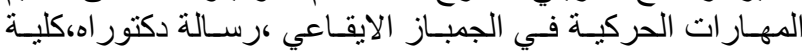
التربية الرياضية للبنات ،جامعة الاسكندرية.

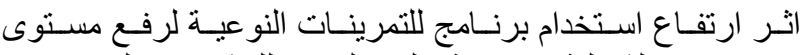

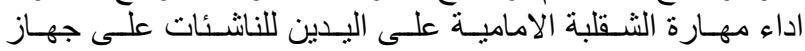

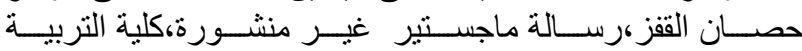
الرياضية للبنين،جامعة الاسكندرية.

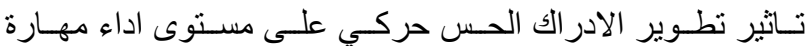

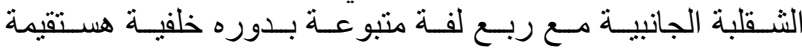

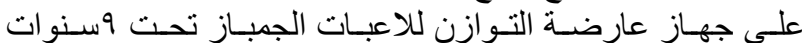

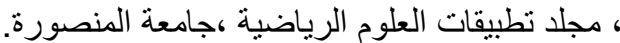

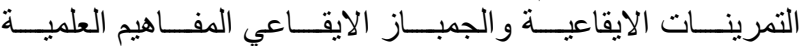
والفنية،مطبعة الغد،القاهرها
$(199 \vee)$

$$
\text { ابو العلا عبد الفتاح }
$$

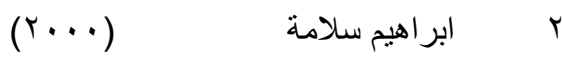

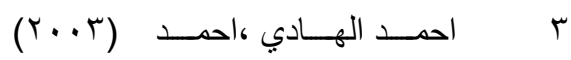

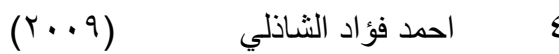

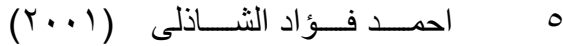

( السيد عبد القصود

اميرة شوفي $\quad$ V V

A

9

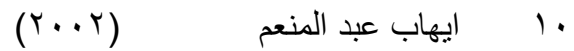

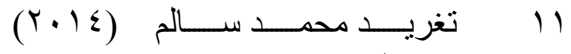

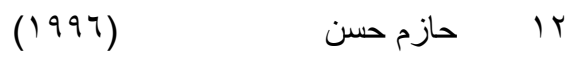

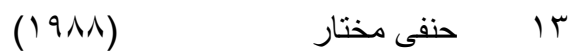

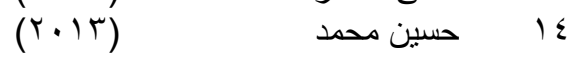

(Y.IV) $\quad 10$

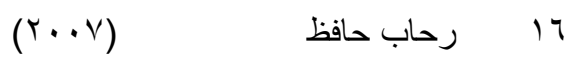

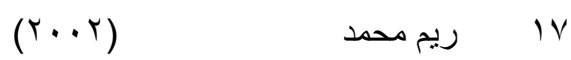

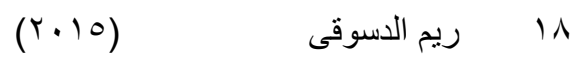

(Y...

(r.1T) $\quad$ Mارة كاشثف

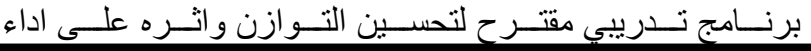

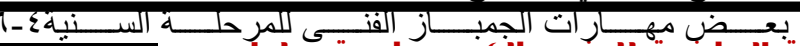




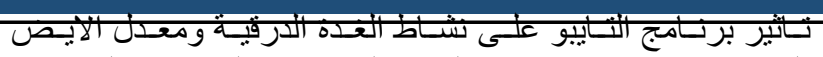

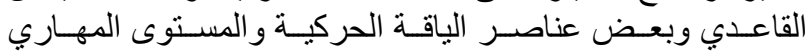

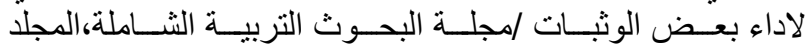

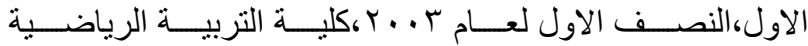
للبنات،جامعة الزقازيقو

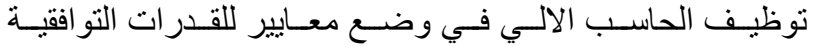

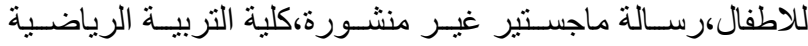
للبنات،جامعة الاسكندرية.

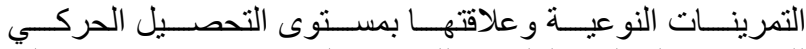

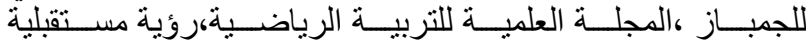

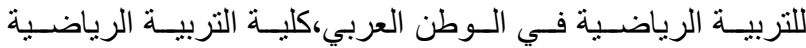

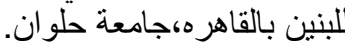

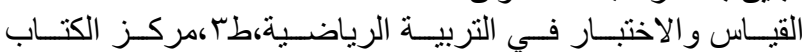
للنشر نالقاهره

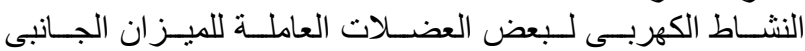

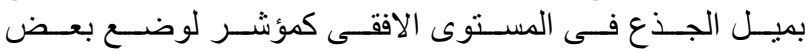

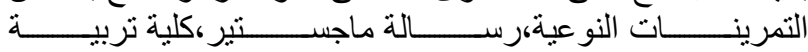
رياضية،جامعة الاسكندرية.

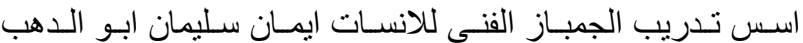

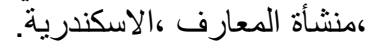
التـدريب الرياضــي و التكامـل بـين النظريــة و التطبيـق ،دار الفكـر العربي، القاهره.

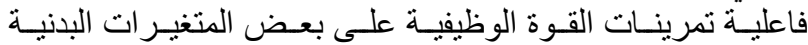

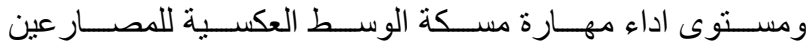
،بحث منشور ،كلية تربية رياضية للبنين،جامعة الزية الزفازيق.

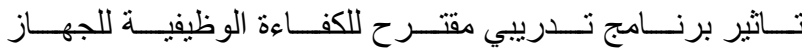

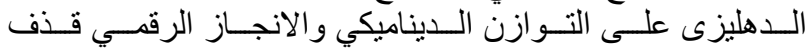

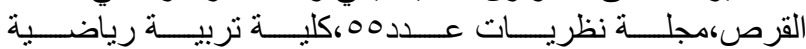
للبنين،جامعة الاسكندرية.

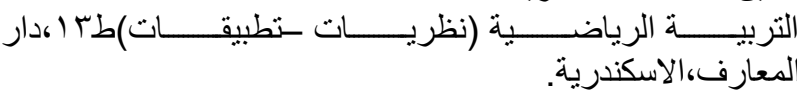

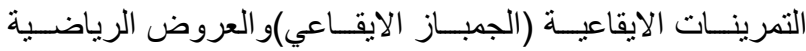
فار الفكر العربي ،القاهرة.

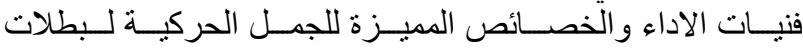

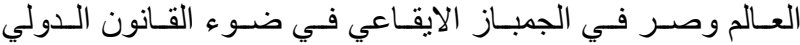

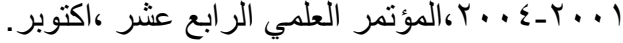

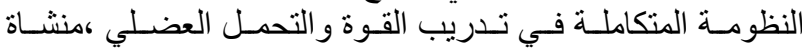
المعارف، الاسكندرية.

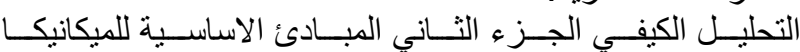

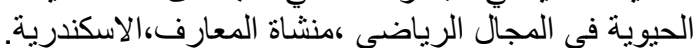

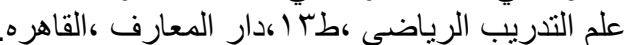

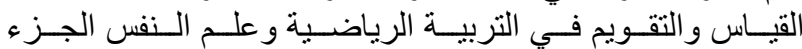

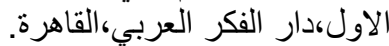
: التذريب الرياضي،منشأة المعارف، الأسكندرية.

القيــاس والتقــويم فــي التربيــة البدنيــة و الرياضــية ،دار الفكــر

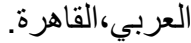

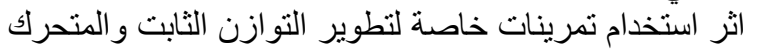

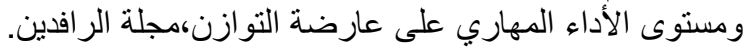

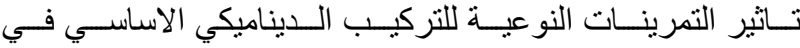

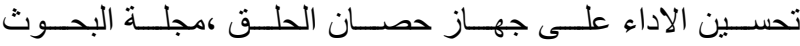
التربية الرياضية للبنات،جامعة الزقازيق. حالتان
$(1 \cdot$,

سلوى سيبد

$(r \cdot \varepsilon)$

شيماء محمد

Yr

$(1994)$

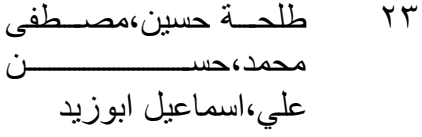

$(r \cdot 0)$

r

$(r \cdot 1 \wedge)$

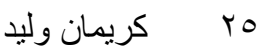

$(r \cdot 1 T)$

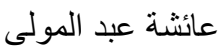

ry

عادل عبد البصير

rV

$(r \cdot 0)$

علاء قناوي

rᄉ

$(Y, 0)$

علاء رجائي

rq

$(r .0)$

عصام عبد الخالق - - مص

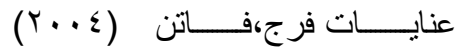
البطل

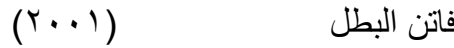

rT

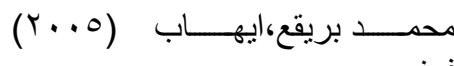

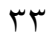

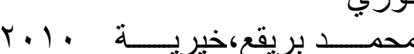
السكري

محمد علاوي م ب محمد علاوي

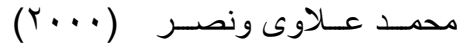
الدين رضو ان

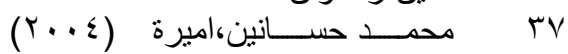

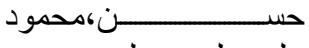
علي، علي سويلم

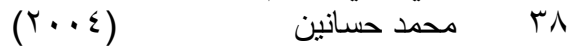

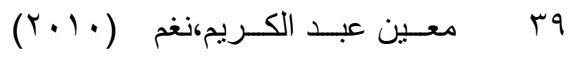
مؤيد

(1999)

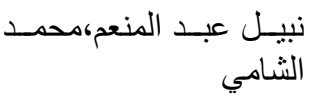

$\varepsilon$. $\varepsilon$ 


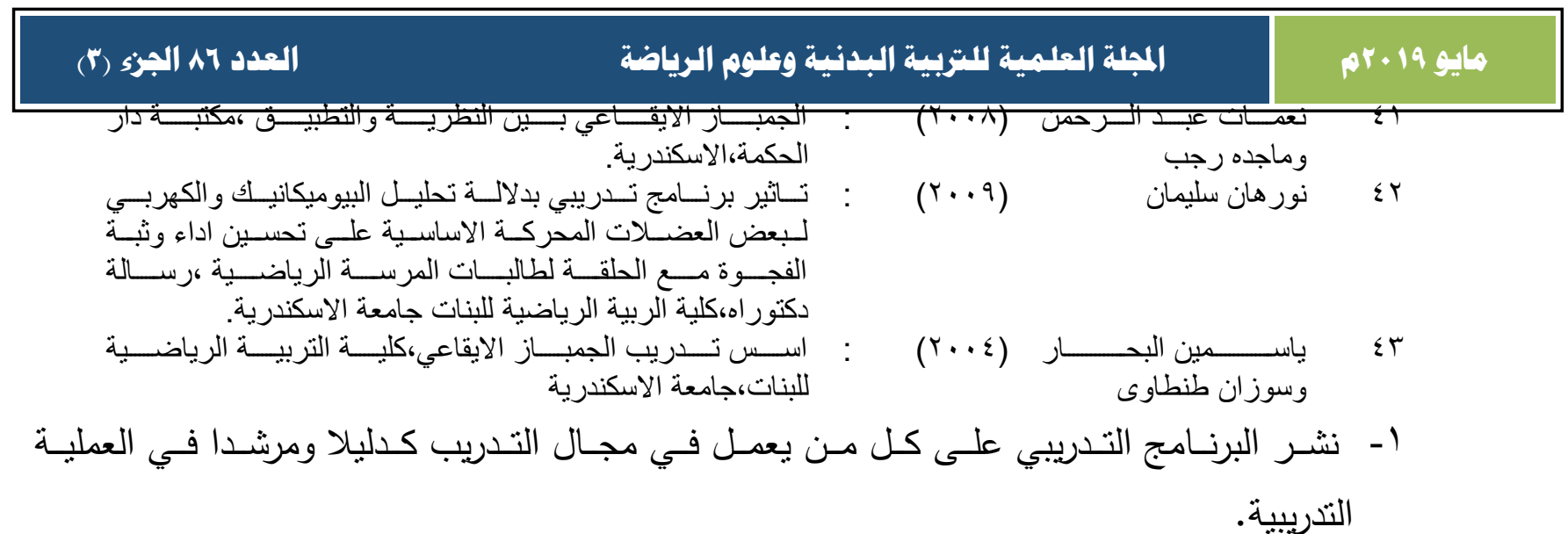

ثانيا المراجع الاجنبية: - n

$\varepsilon \quad$ Alexander (n.d)

$(\uparrow \ldots \wedge$ : Precision muscle balance technology

$\varepsilon$

)

http://dralexander.com/precision-muscle-

balancing-tecgnology

$\leq \quad$ Ana-Maria

$(r \cdot 10$

Study

Old

Regarding

Balance in

in $9-1$. Years

- Gavojdeaa

Physical Education,

Congress of

Kinetotherapy

$\varepsilon$ Bologun, J. A., (1994 : .. The effects of a wobble board exercise

1 Adesinasi, C. O. \&

Marzouk, D. K

training program on static balance

performance and strength of lower

extremity muscles. Physiotherapy Canada, $\varepsilon \varepsilon, r r-r$. .

$\varepsilon \quad$ Davlin, C. D..

Dynamic balance in high level athletes.

V

$(\uparrow \ldots \leq \quad$ Perceptual \& Motor Skills, $9 \wedge, 1) \vee 1-1) \vee \uparrow$

$\varepsilon$ Federation

$(r.) \mathrm{V}:$ :Code of points rhythmic gymnastique

$\wedge$ international de -

gymnastique $\quad r \cdot r \cdot$ )

$\varepsilon \quad$ Gateva, M..

$(r \cdot 1 r:$ : Investigation of the strength abilities of

$9-$

)

rhythmic gymnasts. Research

in

Kinesiology, $\leqslant 1(r), r \leqslant 0 . r \leqslant \wedge$ 
- Kioumourtzoglou, (1999: Experience with perceptual and Motor

. F.

V.,Metzanidou

Derri )

TzetzisG.

Kwon, B. Y

Skills in rhythmic gymnastics ,percept

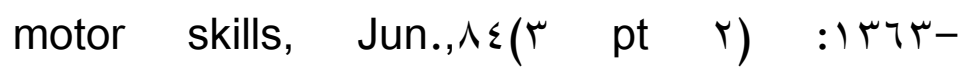
Vr, 1999.

The Effects of Core Stabilization Training for Rhythmic Gymnasts on Balance, Strength, and Flexibility. Korea Institute of $(Y . .9$ : Sport Science, Institute of First Class Match Director. A Report of Applied Field Research of First Class Match Director.

o

Laure s, $(r \cdots)$ Human phgsiology from cells to systems brooks cole publishing ,sa.

Leonardo

Shigaki ।

Lucas

Maciel $(r \cdot 1 r$

Rabellor-r

COMPARATIVE

ANALYSIS

OF

ONE: FOOT BALANCE

Mariana Zingari

- Nadejda Jaster

()999: Rhythmic Human Kinetics,

\& Jembskaia \& Titov )

Yuri

- Maria Gateva

$(r \cdot 17:$ RESEARCH

ON THE

BALANCE

$\circ$ STABILITY OF RHYTHMICGYMNASTICS COMPETITORS

- Mavrovouniotis

(r. $)^{r}$ : DYNAMIC

BALANCE

IN

GIRLS

7 Fotios I, Proios )

PRACTICING RECREATIONAL

Miltiadis ), RHYTHMIC GYMNASTICS AND GREEK

Argiriadou Eirini । \& TRADITIONAL DANCES

Soidou Andromahir 
Miller.d.k

$(1991$

: Measurment

by

the phy

physical

educator why

V

- Ricotti, L

$\wedge \quad$

- Rutkauskaite

9 skarbalius

7 Schurman, C. and how ed wcb hill boston

: Static and dynamic balance in young

$(r \cdot 1) \quad$ athletes.

Journal of Human Sport \& Exercise, $7(\varepsilon)$, 7) T-7イヘ

$r(r+1)$ : Interaction of training and performance ) of 1 r-1 syears old atheletes in rhythmic gymnastics education physical training sport

( $\uparrow \wedge$ : Muscle balance assessment

http://www.bodyresulys.com/erassessmen

t.asp

Strešková, E., \& ( $($.. $q \quad$ : $\quad$ Balance ability level and sport performance in Chren, M.. )

.Latin-American dances

Facta Universitatis Physical Education and Sport, $\vee(1), 91-99$

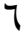

Level coordination ability but efficiency of game Stanistaw,zawhenrk $r \ldots 0$ : of young foot ball players,in physical educatin \&sports,Poland.

1 TATIANA (r. Ir : CHANGES IN

SOMATIC PARAMETERS

r POLISZCZUK ) AND DYNAMIC BALANCE DARIA BRODA , DMYTRO IN FEMALE RHYTHMIC GYMNASTS OVER A SPACE OF TWO YEARS Sport POLISZCZUK

\section{Tourism}


$\uparrow \quad$ Vitrichenko, Klentrou, (Y.)

Rhythmic Gymnastics. Technical Manual. Level

$\varepsilon \quad$..NGorbulina, N., Dell )

r. o0. Lousanne: FIG Academy

a Chiaie, D. \& Fink,

$$
\text { .H }
$$

Groups. In FIG .

(Ed.),

7 . Hrysomallis C.

$(r \cdot 1)$

Balance Ability and Athletic Performance.

0

Horak FB.

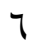

1 Zatsiorsky,v,m

V
Sports Med;乞I:I Yו-rr

( $r \ldots r$ Postural orientation and equilibrium: what do

we need to know about neural control of

balance to prevent falls? Age Ageing; ro Suppl

r:iiv-11

$r \ldots r$ : Kinematics of human motion chamaign il ,human kinetics.

१ http://karate $\{$ arab.com/vb/showthread.php?t= $=\uparrow \wedge \wedge \wedge$

79 http://www.iraqacad.org/Lib/atheer/atheer 1. htm

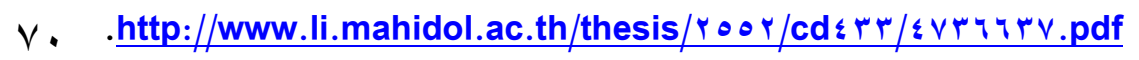

V) http://karate $\leqslant$ arab.com/vb/showthread.php?t= $\mid \vee \wedge \wedge \wedge$

VY http://www.iraqacad.org/Lib/atheer/atheer).htm

vr https://www.youtube.com/watch?v=nCONSMjFdvA

$v \varepsilon \quad$ https://www.youtube.com/watch?v=vr-FDRXiocw

Vo https://www.youtube.com/watch?v=gsovMdnXdLY 